\title{
BIOLOGICALLY-ACTIVE SECONDARY METABOLITES OF FOLIAR ENDOPHYTES OF CONIFERS AND THE UNDERSTORY SPECIES RHODODENDRON GROENLANDICUM FROM THE ACADIAN FOREST
}

Natasha Claudia Prince

A thesis submitted to the Faculty of Graduate Studies in partial fulfillment of the requirements for a degree of

Master of Science

Department of Chemistry

Carleton University

August 2015 


\begin{abstract}
Cronartium ribicola, the causative agent of white pine blister rust is damaging to all five-needle pine species. Existing methods of treatment are largely ineffective, resulting in the need of more innovative approaches. Research has shown that some conifer endophytes produce compounds that display potent antifungal activity, including towards haploid cultures of C. ribicola.

Two conifer and one understory endophytes were studied here. Compounds $1-4$, (1'Z)dechloromycorrhizin $A$ (1), mycorrhizin $A(2)$, chloromycorrhizin $A$ (3) and the new natural product 3-chloro-4-[(1Z)-1'-chloroprop-1'-en-1'-yl]-9-hydroxy-8,8-dimethyl-9,4,5,8-tetrahydro2H-1-benzopyran-5,2-dione (4) were isolated from L. papyraceum. Compounds 5 and $\mathbf{6}$ were produced by $D$. celastrina and were both identified as phomosolide A and a stable C10 pyrone respectively. The remaining compounds 2-(7-methoxy-2,5,6-trimethyl-4-oxo-4 $H$ benzo[d] [1,3]dioxin-2-yl)propanoic acid (7), (E)-6-((3'-carboxybut-2'-en-2'-yl)oxy)-4-methoxy2,3-dimethylbenzoic acid (8) and 2-(6-(hydroxymethyl)-7-methoxy-2,5-dimethyl-4-oxo-4Hbenzo $[d][1,3]$ dioxin-2-yl)propanoic acid (9) were isolated from Seimatosporium sp. and are novel metabolites. All compounds possessed antimicrobial activity in B. subtilis, E. coli, S. cerevisiae and $M$. violaceum assays.
\end{abstract}




\section{Acknowledgements}

Firstly, I give God thanks for His guidance and strength throughout the years of my graduate degree.

Secondly, to my supervisor Dr. David Miller, thank you for the immeasurable support shown, as well as guidance concerning future educational paths. I must thank Dr. Tienabe Nsiama for his hard work and encouragement, as well as colleagues Dr. David McMullin for all his contribution and Blake Green mainly for his hard work as lab Dj. Many thanks to Dr. Keith Seifert, Dr. Joey Tanney and Dr. Allison Walker for their aid in providing and identifying the strains. Many thanks to Dr. Justin Renaud and Dr. Kevin Burgess for all their contribution in the chemical characterization of the compounds.

Thirdly, a special thanks to the people who see me at my best and worst: my family and friends. Thanks to my family for their love and support. Thank you to my good friends Judy Chang, Corina Lim and Elisabeth Mantil for their prayers, support and for being my family away from home.

This work was funded by the National Research Council of Canada, Industrial Research Assistance Program, the Natural Science and Engineering Research Council and JD Irving, Limited. 
Table of Contents

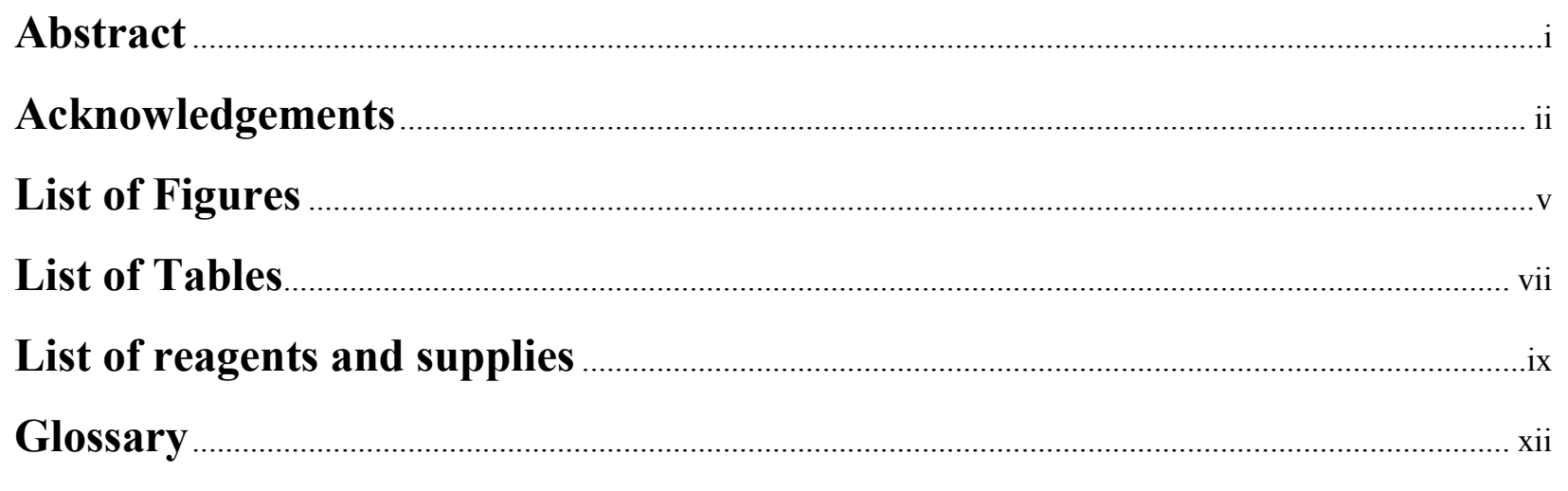

1. Introduction

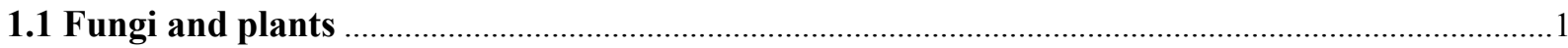

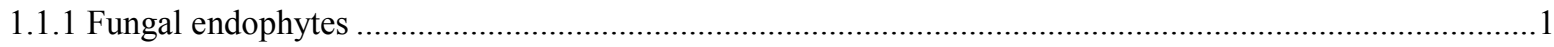

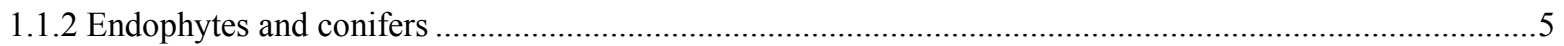

1.1.3 Endophytes as mutualistic symbionts ……............................................................................. 6

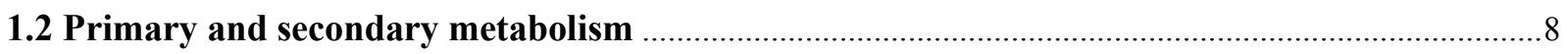

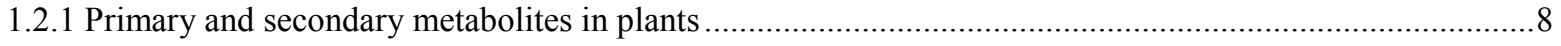

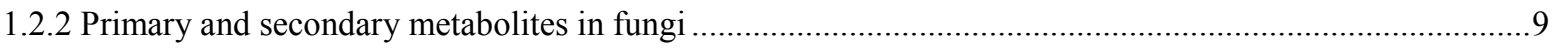

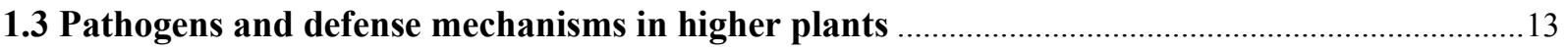

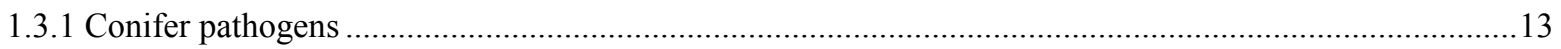

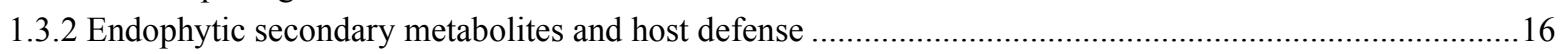

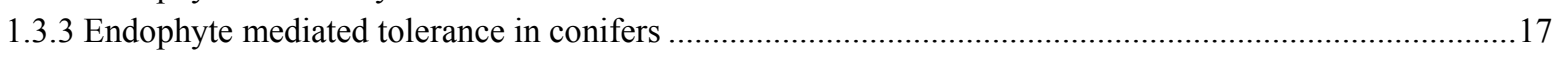

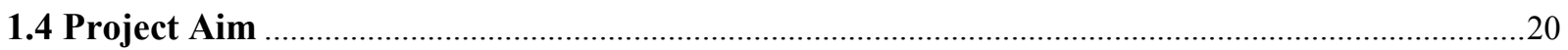

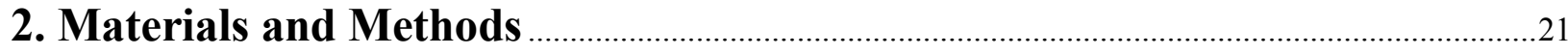

2.1 Fermentation

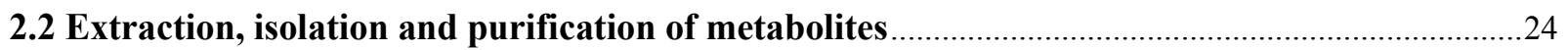

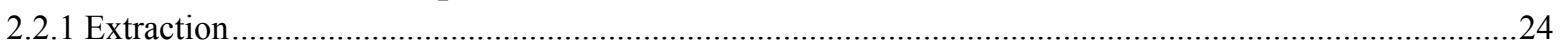

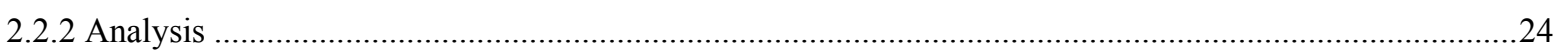

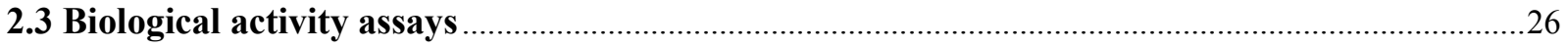

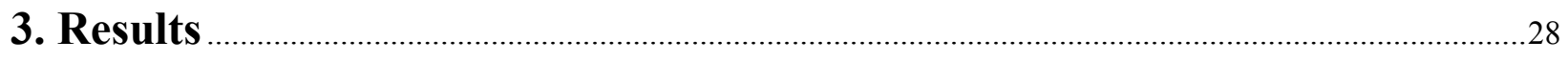

3.1 Secondary metabolites from the Lachnum papyraceum strain ...................................................28

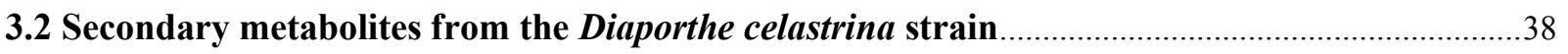

3.3 Secondary metabolites from the Seimatosporium sp. strain .......................................................43

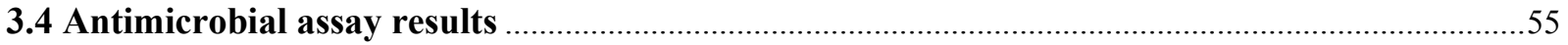

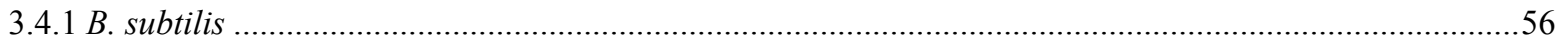

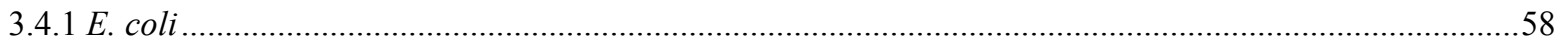




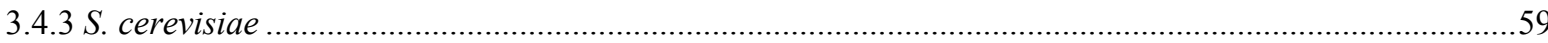

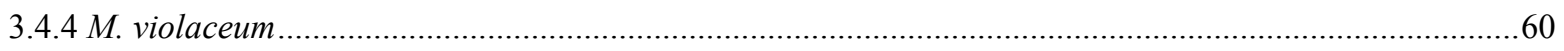

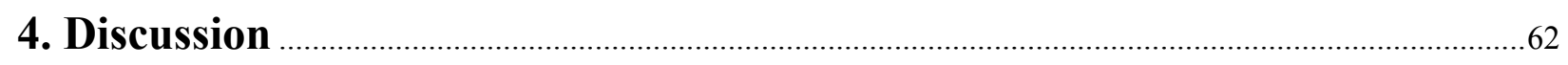

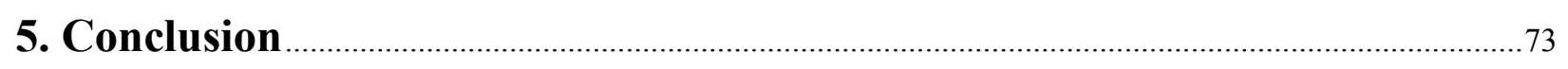

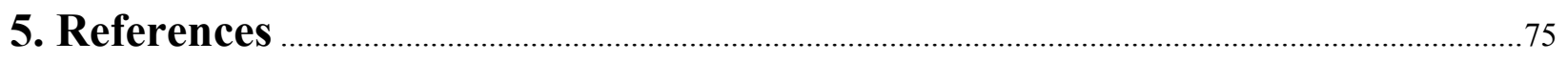

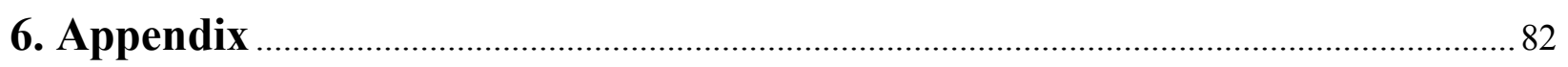

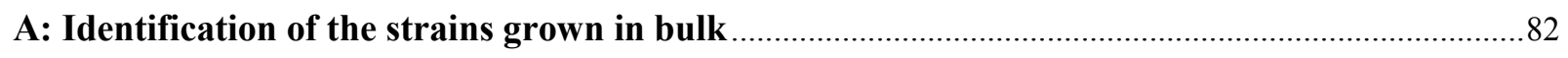

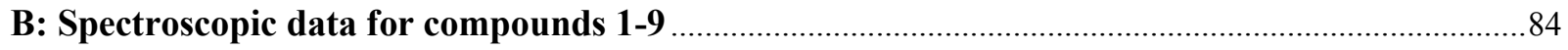

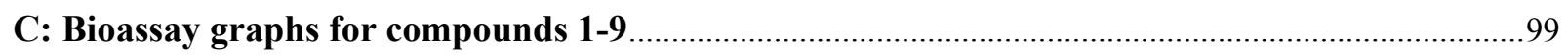

D: Strain collection sites and preliminary bioassay screening results...........................................112 


\section{List of Figures}

\begin{tabular}{llc}
\hline Figure $\quad$ Title & Page
\end{tabular}

Figure 1.1 A simple schematic of the general organization of fungi

Figure 1.2 A common needle endophyte Diaporthe sp., in photo is seen sporulating on spruce twigs as they senesce (a); Tryblidiopsis sp. endophyte sporulates on self-pruned (dead) spruce branches (b); and a Xylaria sp., a very common needle endophyte, seen here sporulating on decaying hardwood

Figure 1.3 Biosynthetic pathway of polyketides

Figure 1.4 Biosynthetic pathway of terpenes

Figure 1.5 Examples of beneficial conifer foliar secondary metabolites, griseofulvin (a), pyrenophorol (b) and rugulosin (c)

Figure 2.1 An overview of the fermentation process of the fungal isolates

Figure 3.1 The structures of compounds 1-3: (1'Z)-dechloromycorrhizin A (1), mycorrhizin A (2) and chloromycorrhizin A (3)

Figure 3.2 Compound 4, 3-chloro-4-[(1Z)-1'-chloroprop-1'-en-1'-yl]-9-hydroxy-8,8dimethyl-9, 4,5,8-tetrahydro-2H-1-benzopyran-5,2-dione

Figure 3.3 Key HMBC and COSY correlations observed for compound 4

Figure 3.4 A related compound, papyracon A

Figure 3.5 Phomopsolide A (5) and a pentaketide alpha pyrone (6)

Figure 3.6 Compound 7, 2-(7-methoxy-2,5,6-trimethyl-4-oxo-4 H-benzo[d][1,3]dioxin-2yl)propanoic acid

Figure 3.7 Key HMBC and COSY correlations observed for compound 7

Figure 3.8 Compound 7.1, Compound 7.1, mono-methylated derivative of compound 7

Figure 3.9 Compound 8, (E)-6-((3'-carboxybut-2'-en-2'-yl)oxy)-4-methoxy-2,3- 
Figure 3.10 Characteristic HMBC correlations observed for compound $\mathbf{8}$

Figure 3.11 Compound 8.1, the diazomethane derivatized form of compound $\mathbf{8}$

Figure 3.12 Compound 9, 2-(6-(hydroxymethyl)-7-methoxy-2,5-dimethyl-4-oxo-4Hbenzo[d] [1,3]dioxin-2-yl)propanoic acid

Figure 3.13 Diagnostic HMBC and COSY correlations observed for compound 9

Figure 3.14 Compounds $1-9$

Figure 4.1 The lineages of L. papyraceum, D. celastrina and Seimatosporium sp.

Figure 4.2 Flowering $R$. groenlandicum (Labrador tea) shrubs among conifers

Figure 4.3 The structures of compound 4 (a) and chloromycorrhizinol A (b) 


\section{List of Tables}

\begin{tabular}{llc}
\hline Table & Title & Page
\end{tabular}

Table 1.1 Several aspects of endophytes according to Rodriguez et al. (2008)

Table 1.2 The main classes of secondary metabolites found in cell cultures and higher 9 plants

Table 3.1 Comparative ${ }^{1} \mathrm{H}$ and ${ }^{13} \mathrm{C}$ NMR data of compounds 1-3 (400.13 MHz, $\mathrm{CD}_{3} \mathrm{OD}$ )

Table 3.2 $\quad{ }^{1} \mathrm{H}$ and ${ }^{13} \mathrm{C} \mathrm{NMR}$ data for compound $4\left(400.13 \mathrm{MHz}, \mathrm{CD}_{3} \mathrm{OD}\right)$

Table 3.3 Summary of the physico-chemical properties of the L. papyraceum compounds

Table 3.4 Comparative ${ }^{1} \mathrm{H}$ and ${ }^{13} \mathrm{C}$ NMR data of compounds 5 and $6(400.13 \mathrm{MHz}$, $\mathrm{CD}_{3} \mathrm{OD}$ )

Table 3.5 Summary of the physico-chemical properties of the D. celastrina compounds

Table 3.6 $\quad{ }^{1} \mathrm{H}$ and ${ }^{13} \mathrm{C} \mathrm{NMR}$ data for compound 7 (400.13 MHz, $\left.\mathrm{CD}_{3} \mathrm{OD}\right)$

Table 3.7 $\quad{ }^{1} \mathrm{H}$ and ${ }^{13} \mathrm{C} \mathrm{NMR}$ data for compound 7.1 (400.13 $\left.\mathrm{MHz}, \mathrm{CD}_{3} \mathrm{OD}\right)$

Table 3.8 $\quad{ }^{1} \mathrm{H}$ and ${ }^{13} \mathrm{C} \mathrm{NMR}$ data for compound $\mathbf{8}\left(400.13 \mathrm{MHz}, \mathrm{CD}_{3} \mathrm{OD}\right)$

Table 3.9 $\quad{ }^{1} \mathrm{H}$ and ${ }^{13} \mathrm{C} \mathrm{NMR}$ data for compound 8.1 (400.13 $\left.\mathrm{MHz}, \mathrm{CD}_{3} \mathrm{OD}\right)$

Table 3.10 ${ }^{1} \mathrm{H}$ and ${ }^{13} \mathrm{C}$ NMR data for compound 9 (400.13 MHz, $\left.\mathrm{CD}_{3} \mathrm{OD}\right)$

Table 3.11 Summary of the physico-chemical properties of isolated Seimatosporium sp. compounds

Table 3.12 Antibacterial activity of compounds 1-9 towards B. subtilis

Table 3.13 Antibacterial activity of compounds 1-9 towards E. coli

Table 3.14 Antifungal activity of compounds 1-9 towards $S$. cerevisiae 
Table 3.15 Antifungal activity of compounds 1-9 towards $M$. violaceum 


\section{List of reagents and supplies}

96-well microplates, pyroplate sterile untreated styrene, certified free of interfering endotoxins \& glucans, Cat. No. CA961, Biolynx inc.

Acetone $\left(\left(\mathrm{CH}_{3}\right)_{2} \mathrm{CO}\right), 1 \mathrm{~L}$ certified A.C.S. reagent grade, CAS No.67-64-1, Caledon Laboratory chemicals

Acetonitrile- $212\left(\mathrm{CH}_{3} \mathrm{CN}\right)$, 4L certified A.C.S. HPLC grade, CAS No. 75-05-8, Caledon Laboratory chemicals

Agar, $1 \mathrm{~kg}$ Laboratory grade (for use in microbiological applications) storage RT, Bioshop, ON, Canada

BD 1mL syringe, Tuberculin slip tip, sterile, REF 309659, NJ, USA

Cap, 9 mm blue screw, PTFE/RS agilent vials caps and septa certification, part No. 5182-0717, Agilent technologies USA

Chloramphenicol $\left(\mathrm{C}_{11} \mathrm{H}_{12} \mathrm{C}_{22} \mathrm{~N}_{2} \mathrm{O}_{5}\right), 25 \mathrm{~g}$ (chloromycetin) stored at room temperature, EEC No. 200-287-4 Sigma, St. Louis USA

D-glucose $\left(\mathrm{C}_{6} \mathrm{H}_{12} \mathrm{O}_{6}\right)$, anhydrous A.C.S. analytical reagent $[\alpha]_{D}^{25^{\circ} \mathrm{C}}+52.5^{\circ}$ to $+53.0^{\circ}, \mathrm{ACS} 369$, BDH, ON, Canada

Dimethyl sulfoxide $\left(\mathrm{SO}\left(\mathrm{CH}_{3}\right)_{2}\right), 500 \mathrm{~mL}, \geq 99.9 \%$ purity A.C.S. spectrophotometric grade, EC 200-664-3, Sigma Aldrich, St. Louis, USA

Disposable Pasteur pipets, $5^{3} / 4$ " borosilicate glass non-sterile, Cat. No. 13-678-20A, Fisher brand, Fisher Scientific, USA 
Disposable Pasteur pipets, 9" borosilicate glass non-sterile, Cat. No. 13-678-20C, Fisher brand, Fisher Scientific, USA

Eppendorf Research/ BioHit proline pipettes (microliter)

Ethyl acetate $\left(\mathrm{C}_{4} \mathrm{H}_{8} \mathrm{O}_{2}\right)$, 4L A.C.S. certified reagent grade, CAS No.141-78-6, Caledon Laboratory chemicals

Ehtyl alcohol, 4L 95\%, ON Canada

Filter paper No. 1, qualitative circles $24.0 \mathrm{~cm}$, Cat. No. 1001-240, Whatman GE Healthcare, UK

Filter paper No. 4, qualitative circles $24.0 \mathrm{~cm}$, Cat. No. 1004-240, Whatman GE Healthcare, UK

Fleischmann's traditional active dry yeast, $113 \mathrm{~g}, \mathrm{ON}$, Canada

Formic acid (HCOOH), $500 \mathrm{~mL}$ 98\%, A.C.S. certified, CAS No. 64-18-6, EMD

Graduated pipet tips, 101-1000 $\mu \mathrm{L}$, blue, free of detectable RNase, DNase and DNA, Cat. No. 1111-2021, Tip One, USA scientific inc.

Hexanes $\left(\mathrm{CH}_{3}\left(\mathrm{CH}_{2}\right)_{4} \mathrm{CH}_{3}\right)$, 4L A.C.S. certified spectro grade, CAS No. 110-54-3, Caledon Laboratory chemicals

Kimwipes, Kimtech science brand

Malt extract, 10kg, Cat. No. DFO186088, Bacto, Becton, Dickinson and Co. (BD), Le Pont de Claix, France

Methanol $\left(\mathrm{CH}_{3} \mathrm{OH}\right)$, 4L A.C.S. certified HPLC grade, CAS No. 67-56-1, Caledon Laboratory chemicals 
Methanol $\left(\mathrm{CH}_{3} \mathrm{OH}\right)$, 4L A.C.S. certified reagent grade, CAS No. 67-56-1, Caledon Laboratory chemicals

Methyl alcohol-d 4 (CD 3 OD), 10g 99.8 atom \%D, CAS No. 811-98-3, CDN Isotopes, PointeClaire, QC, Canada

Natural pipet tips, 0.5-10 $\mu \mathrm{L}$, RNase, DNase, DNA and pyrogen free, Cat. No. 1111-4000, Tip One, USA scientific inc.

Nystatin, $870 \mathrm{mg}$ powder bioreagent suitable for cell culture stored at $-20^{\circ} \mathrm{C}$, CAS No. $1400-61$ -

9, Sigma Aldrich,

St. Louis, USA

Parafilm, 4 in. x 125 ft roll, laboratory film, PM 996, USA

Peptone, $2 \mathrm{~kg}$ enzymatic digest of protein, Ref. 211820, Bacto, Becton, Dickinson and Co. (BD), Le Pont-de-Claix, France

Petri dishes, sterilized-disposable plastic, 100 O.D. x $15 \mathrm{~mm}$, polystyrene

pH Buffer pH 4, 500mL red, BD 15018, BDH General

pH Buffer pH 7, 500 mL, BD H5052, BDH General

PTFE syringe filter, hydrophilic $0.22 \mu \mathrm{m}$ pores, $13 \mathrm{~mm}$ diameter, Tisch scientific

Roux bottle, Pyrex brand Roux bottles with offset neck, 500 mL, Sigma-Aldrich, Cat. No. CLS1290, St. Louis USA

Screw thread vials, 17 x 60 mm, 2Dr, amber rubber lined cap, Cat. No. 24-0080-003, USA 
Screw thread vials, 17 x $60 \mathrm{~mm}, 2 \mathrm{Dr}$, rubber lined cap, Cat. No. 03-339-25C, Fisher brand, Fisher scientific, USA

Serological disposable glass pipet, $10 \mathrm{~mL}$ in $1 / 10$, orange sterile, borosilicate plugged individually non-pyrogenic, Cat. No. 93000-698

Sodium chloride ( $\mathrm{NaCl}$ ), 5kg hygroscopic 99.0\% purity reagent grade, CAS No. 7647-14-5, Bioshop, ON, Canada

Sodium hypochlorite, 5L, 10.3\%, Cat. No. 0105-0031, Bleach Javex 12, Clorox

Sodium sulfate $\left(\mathrm{Na}_{2} \mathrm{SO}_{4}\right), 10 \mathrm{~kg}$ anhydrous A.C.S. $10^{\text {th }}$ ed. reagent grade, CAS No. 7757-82-6, Amachemia, QC, Canada

Sucrose $\left(\mathrm{C}_{12} \mathrm{H}_{22} \mathrm{O}_{11}\right), 1 \mathrm{~kg}$ ultra-pure (purity min. 99.5\%), Cat. No. Suc507.1

Vial insert, $250 \mu \mathrm{L}$, pulled point glass, part No. 5183-2085, Agilent technologies USA

Vial, screw 2mL, amber, agilent auto sampler approved part No. 5182-0716, Agilent technologies, USA

Weighing paper, 3" x 3", Cat. No. 09-898-12A, Fisher brand, Fisher scientific, USA

Yeast extract, powder, CAS No. 8013-01-2, Sigma Lifescience, St. Louis, USA

\section{Glossary}


$\mathrm{ACN}$ :

Angiosperms:

COSY:

DAD:

dd:

DEPT:

DMSO:

dq:

ESI:

EtOAc:

ETOH:

Gall:

Gymnosperms:

HMBC:

HPLC:

HR-ESI-MS:

HRMS:

HSD:

HSQC:

Hypha:

ITS:

$\mathrm{J}$ :

LC-MS:
Acetonitrile

Flowering plants that produce seeds enclosed in ovaries

Correlated spectroscopy $\left({ }^{1} \mathrm{H}\right.$ NMR $)$

Diode-array detector

Doublet of doublet (NMR)

Distortionless enhancement by polarization transfer $\left({ }^{13} \mathrm{C} N \mathrm{NM}\right)$

Dimethyl sulfoxide

Doublet of quartet (NMR)

Electrospray ionization (MS)

Ethyl acetate

Ethanol

The development of plant tissue in response to the feeding or breeding activity of insects or mites

Seed-bearing plants in which the seeds develop on the surface of reproductive structures, for example pine cones

Heteronuclear multiple bond correlation spectroscopy $\left({ }^{1} \mathrm{H}\right.$ and $\left.{ }^{13} \mathrm{C} \mathrm{NMR}\right)$

High-performance liquid chromatography

High-resolution electrospray ionization mass spectrometry

High-resolution mass spectrometry

Tukey’s honest significant difference test

Heteronuclear singular quantum correlation $\left({ }^{1} \mathrm{H}\right.$ and $\left.{ }^{13} \mathrm{C} \mathrm{NMR}\right)$

(Plural hyphae) threadlike filament forming the mycelium of a fungus

Internal transcribed spacer region (Fungal identification)

Coupling constant in $\mathrm{Hz}(\mathrm{NMR})$

High-Performance liquid chromatography coupled to mass spectrometry 


\begin{tabular}{ll} 
Me: & Methyl group $\left({ }^{13} \mathrm{C}\right.$ NMR) \\
MeOH: & Methanol \\
Microepiphytes: & Fungi residing on the surface of plants \\
min.: & Minutes \\
MS: & Mass spectrometry \\
Mycelium: & (Plural mycelia) the mass of branched hyphae of fungi \\
MW: & Molecular weight (Da) (MS) \\
$m / z:$ & Mass to charge ratio (MS) \\
NMR: & Nuclear magnetic resonance \\
OD: & Optical density \\
OMe: & Oxygen bonded to a methyl group $\left({ }^{13} \mathrm{C} \mathrm{NMR)}\right.$ \\
OR: & Optical rotation \\
q: & Quadruplet (NMR) \\
q- Pcr: & Quantitative polymerase chain reaction \\
r.t.: & Retention time (HRMS) \\
s: & Singlet (NMR) \\
$s p:$ & Unidentified or unspecified species \\
t: & Triplet (NMR) \\
UV: & Ultra-violet \\
\hline
\end{tabular}




\section{Introduction}

\subsection{Fungi and plants}

\subsubsection{Fungal endophytes}

The fungal kingdom is composed of highly diverse unicellular and multicellular organisms. A simplified chart depicting the hierarchy of fungi is illustrated in Figure 1.1 below.

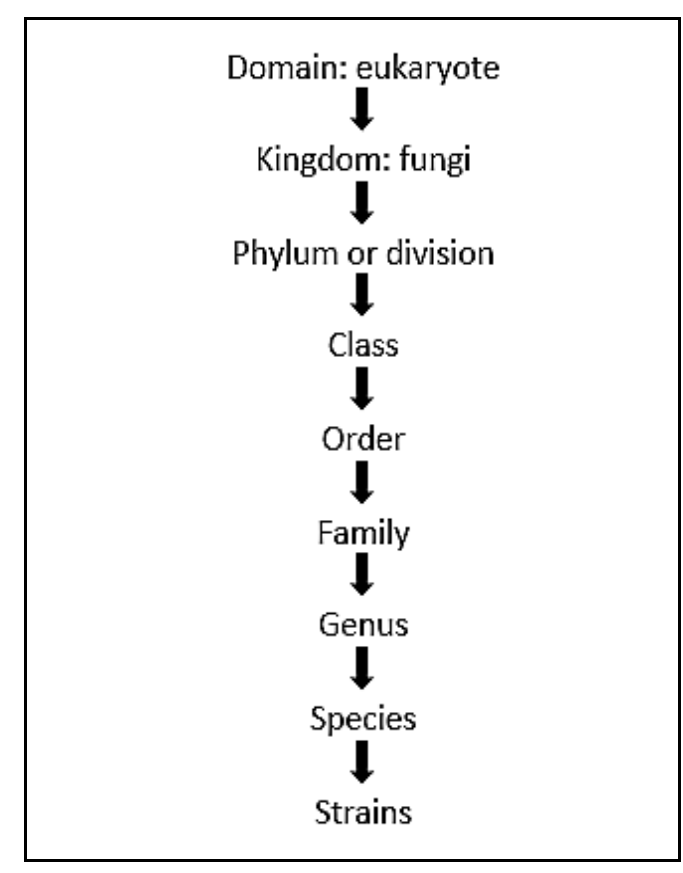

Figure 1.1 A simple schematic of the general organization of fungi.

Fungi are ubiquitous in the environment and can thrive on virtually any organic matter in the presence of sufficient moisture (Ferreira et al. 2006). Some fungi (and bacteria), termed endophytes can colonize living plant tissue without causing visible harm. Specifically, endophytes are endosymbionts that inhabit living plants for part of the life cycle of the fungus 
(Carroll 1986; Clay \& Schardl 2002) (Figure 1.2). Endophytes have been found in all plant types studied to date (Arnold \& Lutzoni 2007).
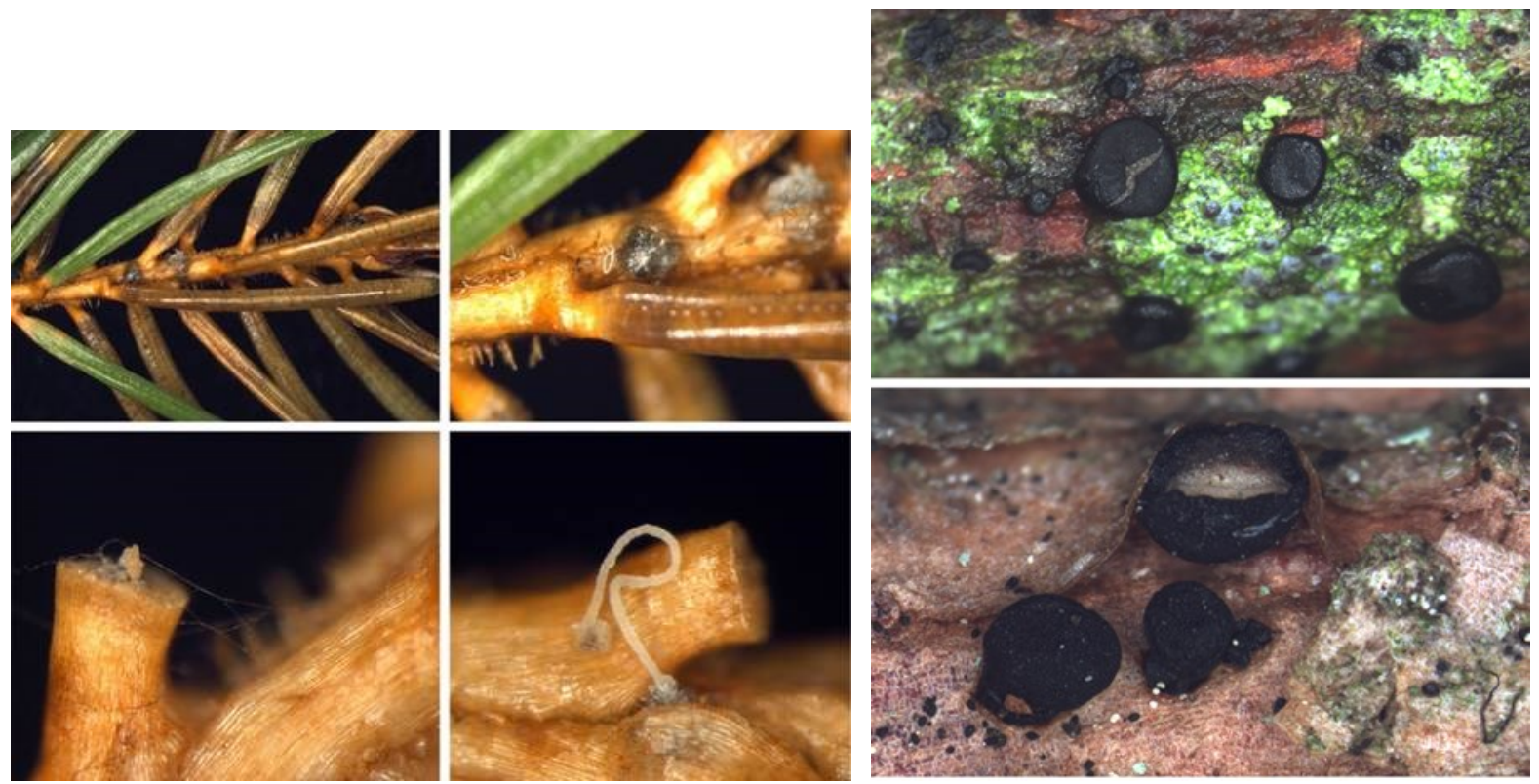

$\mathrm{a}$
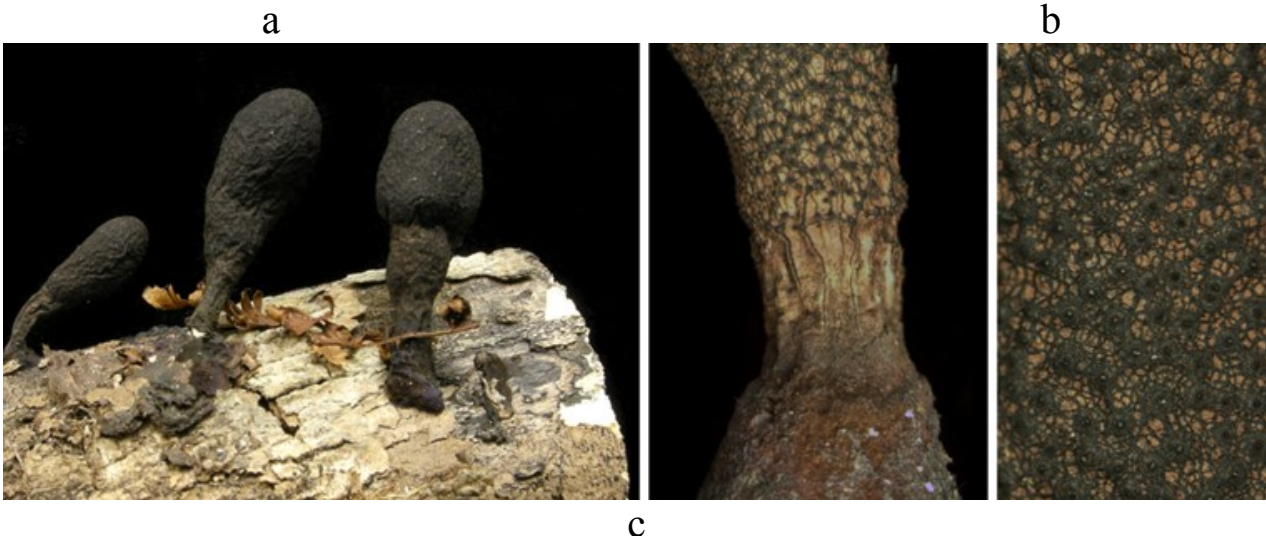

Figure 1.2 A common needle endophyte Diaporthe sp., in photo is seen sporulating on spruce twigs as they senesce (a); Tryblidiopsis sp. endophyte sporulates on self-pruned (dead) spruce branches (b); and a Xylaria sp., a very common needle endophyte, seen here sporulating on decaying hardwood.

The relationship between endophytes and their host plants operates along the symbiotic continuum, ranging from a mutualistic association to commensalism, to parasitism (Aly et al. 2011; Larkin et al. 2012). Some endophytes are suspected to have evolved from parasitic or pathogenic fungi (Carroll 1988). Transition from a quiescent to parasitic stage can occur when environmental changes become more advantageous for the fungus over that of the host plant 
(Schulz et al. 1995; Schulz et al. 2002; Sieber 2007). The main differences between the endophytic-plant verses the pathogenic fungi-plant interactions are observed in their different modes of growth. In bean and barley for example, endophytic fungi grew within the stomata, having low fungal biomass (Carroll 1988) and resulting in local and intercellular growth. Pathogenic fungi were able to penetrate plant cell walls (Boyle et al. 2001). Endophytic distribution is considered to be influenced by climatic factors. Arnold \& Lutzoni (2007) isolated 1403 endophytic strains from both angiosperms and gymnosperms ranging from the Canadian arctic to central Panama. It was found that the communities of endophytes in higher latitude regions were characterized by a lower species diversity represented by a higher number of fungal classes. The opposite was observed in tropical regions, as these communities consisted of higher endophytic species diversity from a fewer number of classes.

There exist some marked differences in the types of endophytes that can colonize different plants, as well as the type of interaction between endophytes with their respective host plants. Some endophytes demonstrate a high level of host specificity. For example, dominant endophytes of angiosperms generally belong to the order of Diaporthales, while those in gymnosperms are more associated with the Helotiales. Contrarily, other endophytes within the following orders Dothideales, Pleosporales, Mycosphaerellales and Xylariales have low host specificity and can be dominant in both angiosperms and gymnosperms (Sieber 2007).

The best studied plant-endophyte system to date is that of the grasses and their endophytes (Clay \& Schardl 2002). As a result, it is common that fungal endophytes are categorized as clavicipitalean or non-clavicipitalean (Carroll 1988). Clavicipitalean is found to infect cool 
season fescues systemically, without infecting the roots. Non-clavicipitalean endophytes on the other hand colonize their hosts in a non-systemic manner and can be found in all plant types in moderate climatic zones (Carroll 1988). Both families of endophytes are within the phylum Ascomycota and possess different characteristics, some of which are noted in Table 1.1.

Table 1.1 Several aspects of endophytes according to Rodriguez et al. (2008).

\begin{tabular}{|c|c|c|}
\hline & Clavicipitaceous (C) & Non-clavicipitaceous (NC) \\
\hline host range & narrow & broad \\
\hline tissue(s) colonized & shoot and rhizome & shoot, root and rhizome \\
\hline $\begin{array}{c}\text { in planta } \\
\text { colonization }\end{array}$ & extensive & limited \\
\hline $\begin{array}{l}\text { in planta } \\
\text { biodiversity }\end{array}$ & low & ranges from low to high \\
\hline transmission & $\begin{array}{c}\text { vertical (predominantly) and } \\
\text { horizontal }\end{array}$ & vertical and horizontal \\
\hline
\end{tabular}

Endophytes classified as non-clavicipitalean tend to be restricted to specific tissues and are directly related to tissue age (Arnold \& Lutzoni 2007). Vertical transmission of endophytes is more common amongst the clavicipitalean group, in contrast to the higher tendency of horizontal transfer in the non-clavicipitalean group. Horizontal transmission of endophytes occurs when asexual spores of endophytes are transported to the leaves of a plant (Saikkonen et al. 1998). These then germinate and release exoenzymes used to soften the epidermal cells, and permit the hyphae to penetrate the leaves (Schulz et al. 2002). In order for an endophyte to colonize a plant, it must first be compatible with the host and overcome the /plant defense systems.

Non-clavicipitalean endophytes are found in a wide array of woody plants and are phylogenetically highly diverse. Non-clavicipitalean endophytes in general are in different 
fungal taxa from the pathogens associated with their plant hosts (Ganley et al. 2004). These types of endophytes are comprised mainly of those within the sub-kingdom Dikaryomycota, (the phyla Ascomycota and Basidiomycota), as well as the sub-phyla Pezizomycotina and to a lesser extent, Saccharomycotina (Rodriguez et al. 2008).

\subsubsection{Endophytes and conifers}

The infection pattern in conifers has been described in the foliage of Douglas fir by the dominant endophyte Rhabdocline parkeri. Infection is generally observed within single epidermal cells in which the growth pattern of the hyphae follow along the shape of the cell. Because only singlecell infection occurs, older needles tend to have more separate infections in comparison to younger needles. The conidia of $R$. parkeri produces an appressorium following germination to facilitate the penetration of the plant epidermal cell wall by the hyphae (Stone 1987). The hyphae of a second common endophyte found in Douglas fir, Phyllosticta sp., demonstrates intercellular growth between epidermal cells and intracellular growth as needles senesce (Carroll 1986). Microscopy studies of balsam fir (Abies balsamea) and red spruce (Picea rubens) needles also illustrated intercellular growth of endophytic hyphae (Johnson \& Whitney 1989).

In two consecutive studies conducted by Stefani and Berube (2006 \& 2006a), investigation of pine foliar endophytes from genetically transformed and non-transformed trees both had the same dominant endophyte, Lophodermium piceae ( $>74 \%$ in both tree types). Other minor endophytes present in the transformed trees were Hypoxylon fragiforme (3.63\%) and Lopherderimium nitens $(3.18 \%)$. In the non-transformed tree study, other minor species were

present from the genus Mycosphaerella (10.95\%) and Hypoxylon (5.5\%) (Stefani \& Berube 
2006a). These findings are congruent with what was observed in the study by Arnold and Lutzoni (2007) that fewer species are in trees at higher latitudes.

Different plant tissues can be infected by varying levels and different types of endophytes. Conifers are known to harbour greater species diversity in needles in comparison to any other plant tissues (Johnson and Whitney 1992; Ganley et al. 2008). Needles of all ages can be infected with endophytes, however older needles appear to have a greater vulnerability towards infections by more than one endophyte. This was observed in Picea sitchensis (Sitka spruce) (Magan and Smith 1996), Picea mariana (black spruce) (Johnson and Whitney 1992), and Pinus strobus (white pine) (Deckert \& Peterson 2002). Stone (1987) hypothesized that this was attributable in part to the increase in needle microepiphytes. These organisms could weaken the leaves as they senesce, allowing for easier colonization by endophytes.

\subsubsection{Endophytes as mutualistic symbionts}

There have been many reports concerning the benefits for plant hosts infected with endophytes. These benefits were first documented using three principal host-endophyte-grazer systems: grasses, angiosperms and gymnosperms (Carroll 1988). These systems represent clear illustration of the mutualism between these symbionts and their plant hosts, by the antagonistic effects towards herbivores of the host plant. The first, involves the Balansia endophytes and grasses. Endophyte infected tall fescues resulted in increased tolerance towards herbivorous insects and grazing animals (Clay 1988). The second system described was that of elm trees and the endophyte Phomopsis oblanga (Webber 1981). Elm bark beetles are vectors for Ceratocystis ulmi, the fungus responsible for Dutch elm disease (Carroll 1988). Beetles feeding on the bark of 
elm trees that were infected with $P$. oblanga displayed decrease in breeding activity and reductions in population sizes when compared to beetles feeding on uninfected tree bark. The third system was that of Douglas fir needles and the dominant endophyte $R$. parkeri. In his study on Douglas fir, Carroll (1986) observed that the presence of $R$. parkeri in needle galls had an antagonistic effect on gall midges within the genus Contarinia. Evaluation of endophyte-infected and uninfected galls revealed a higher larval mortality rate in infected galls. All other parameters considered, it was presumed that mortality was a result of toxins produced by $R$. parkeri.

Carroll (1988) defined mutualism as being constitutive or inducible. Constitutive mutualism is observed primarily in the grass-endophyte system described above. Endophytes are vertically transferred and are therefore continuously present in new generations. These endophytes are directly involved in the protection of their hosts by producing metabolites that prevent herbivory (Clay 1988). Inducible mutualism is observed in angiosperms and gymnosperms. In these systems, endophytes are horizontally transferred; the extent of endophytic infection is influenced by geographic locations and host age. Consequently, tree endophytes do not have the fixed mutualistic association as that observed between grasses and their endophytes. Generally, fungi remain in aging tissues (for example, in the epidermis) and will only colonize other key tissues once hosts are injured or under stress (Carroll 1988).

The beneficial effects of endophytes are directly related to the secondary metabolites they produce in planta. Consequently, most of the research dedicated to the study of tree endophytes is focused on the discovery of bioactive chemicals produced through secondary metabolism. 


\subsection{Primary and secondary metabolism}

\subsubsection{Primary and secondary metabolites in plants}

Metabolites are described as products of cellular regulatory processes; their quantities correspond to responses towards environmental stimuli as well as genetic patterns of the producing organism (Kralova et al. 2012). Secondary metabolites are produced by all plant types and are described as a group of low molecular weight chemicals, often exhibiting interesting physiological activities (Keller et al. 2005). Despite the high structural diversity among these chemicals (see Table 1.2), the production of secondary metabolites arise from a few known biosynthetic pathways. Secondary metabolism is often associated with a specific morphological developmental stage (Keller et al. 2005; Sumarah \& Miller 2009). Further, the production of these metabolites is not necessary for the growth or biological function of the producing organism. However, secondary metabolite can be important for the survival of the colony.

Secondary metabolite production is influenced by environmental conditions, such as nutrient availability (carbon and nitrogen sources) and oxygen tension. There exists a defined set of metabolites that can be produced by a given fungus; in other words, no fungus can produce an unlimited number of secondary metabolites (Miller 1986). This set of metabolites is defined as the metabolome. The study of the metabolome is a recent approach used by researchers in an effort to understand the vast diversity of secondary metabolites produced by plants (Bertoli et al. 2010). 
Table 1.2 The main classes of secondary metabolites found in cell cultures and higher plants (Bertoli et al. 2010).

\begin{tabular}{lclll}
\hline Phenylpropanoids & Alkaloids & Terpenoids & Quinones & Steroids \\
\hline Anthocyanins & Acridines & Carotenes & Anthroquinones & Cardiac glycosides \\
Proanthocyanidins & Indoles & Triterpenes & Benzoquinones & $\begin{array}{l}\text { Pregnenolone } \\
\text { derivatives }\end{array}$ \\
Coumarins & Betalaines & Monoterpenes & Naphthoquinones & \\
Flavonoids & Quinolizidines & Sesquiterpenes & & \\
$\begin{array}{l}\text { Hydroxycinnamoyl } \\
\text { derivatives }\end{array}$ & Furnoquinones & Diterpenes & & \\
Isoflavanoids & & & \\
Lignans & Isoquinolines & & \\
Phenolenones & Purines & & \\
Stilbenes & Pyridines & & \\
Tanins & Tropane alkaloids & & \\
\hline
\end{tabular}

\subsubsection{Primary and secondary metabolites in fungi}

Secondary metabolites produced by fungi has been studied since the early 1920's (Keller et al. 2005). Fungal secondary metabolites are described as compounds whose production is induced by changes in environmental conditions. This is evidenced in vitro by the absence of secondary metabolites in culture broth that provides the fungus with all the necessary nutrients, and in which growth conditions are favorable. During the stationary phase, mycelial growth halts but cells are still undergoing metabolic activity. It is during this phase where secondary metabolites are produced by fungi. Environmental factors that influence the type of metabolites produced include the nature of the limiting nutrient (carbon, nitrogen or phosphate) as well as the genetic 
makeup of the fungus. Depending on the nature of the nutrient limitations (defined here as the period when all easily metabolized carbon or nitrogen have been used up), different types of secondary metabolites can be synthesized (Miller 1986; Sumarah \& Miller 2009). Other factors such as geographic location, climate, and host plants can determine the types of fungal endophytes and therefore the secondary metabolites in any given ecology (Ding et al. 2013).

Secondary metabolism and the levels of secondary metabolite production in plants generally vary per tissue type. Hunt and Von Rudloff $(1974,1977)$ found that fir needles contained greater levels of certain metabolites in comparison to the cortex and xylem.

Fungal secondary metabolites are classified according to the types of enzymes involved in their biosynthesis. Some of the most common types of secondary metabolites include polyketides, terpenes, coumarins, alkaloids and peptides (Keller et al. 2005). Polyketide synthesis is the most common route of fungal metabolites. Polyketide synthesis is achieved by an enzyme complex known as type I polyketide synthases, bearing similar structures to eukaryotic fatty-acid synthases. The synthesis of these metabolites involves the condensation of small carboxylic acids, namely acetyl coenzyme A (acetyl CoA), and malonyl CoA. From this, linear ketides are formed, which can further undergo cyclization to form many different chemicals. If modified, malonate can also lead to the formation of fatty acids (see Figure 1.3). 


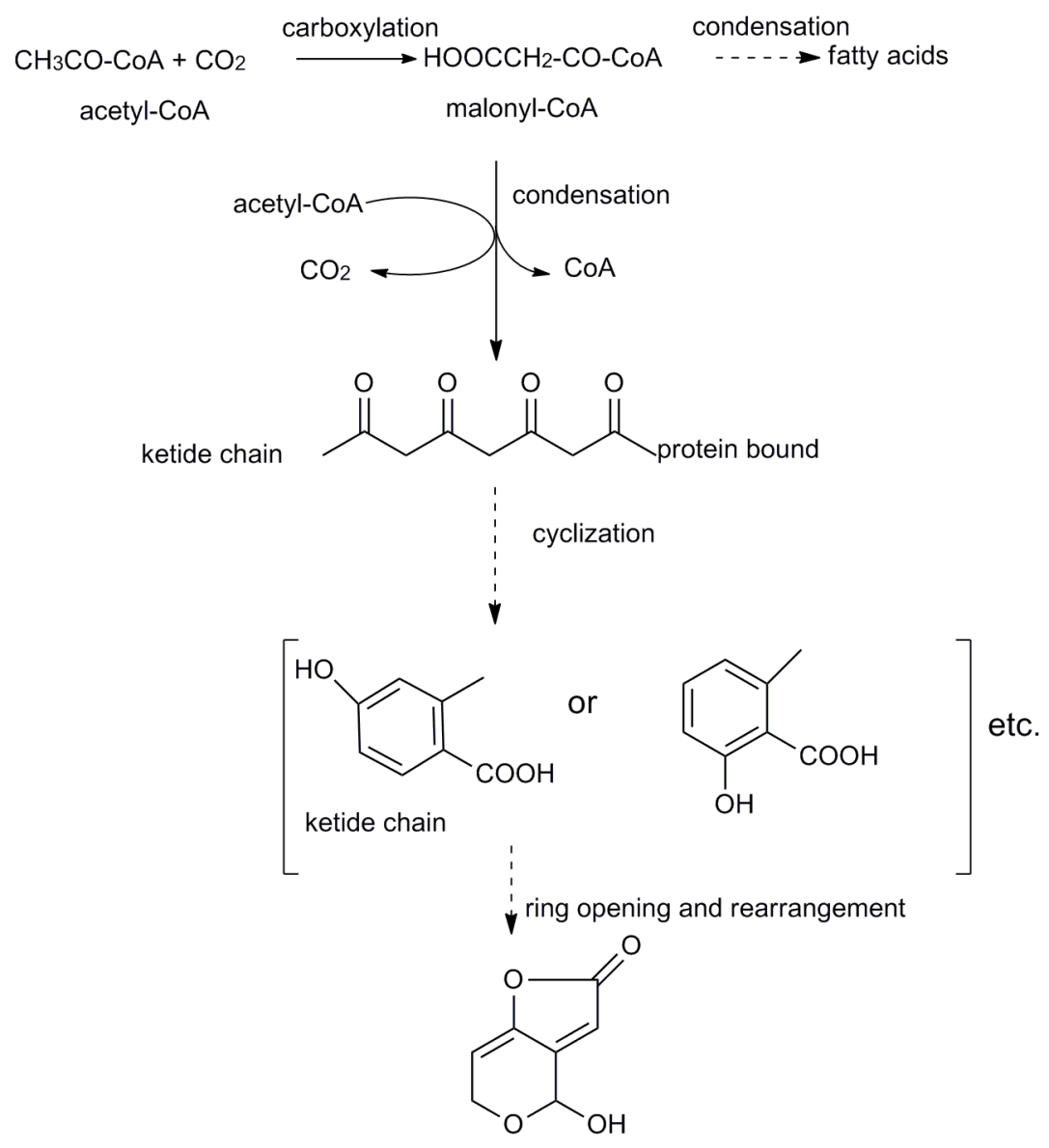

Figure 1.3 Biosynthetic pathway of polyketides (Deacon 2005).

In the formation of polyketides, other CoA esters can initiate chain assembly. For example, malonyl CoA units can be substituted for propionate units during chain lengthening (Robinson 1991).

Terpenes contain multiple isoprene units and are synthesized primarily by the terpene cyclase enzyme. The synthetic pathway is illustrated in Figure 1.4. 


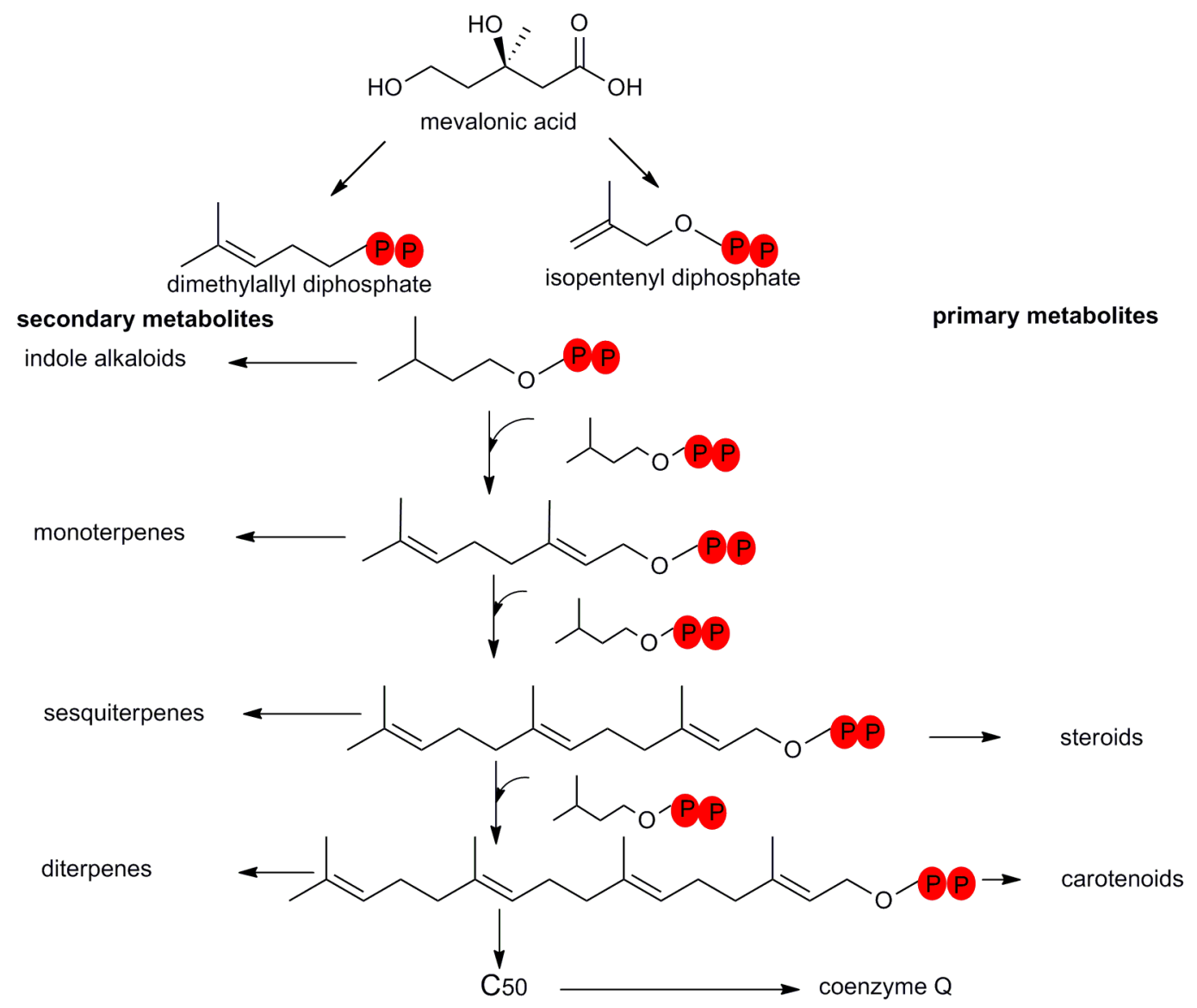

Figure 1.4 Biosynthetic pathway of terpenes (Keller et al. 2005).

Coumarins and cinnamic acid metabolites are produced from shikimic acid and do not usually contain nitrogen. Indole alkaloids are predominantly developed from aliphatic and aromatic amino acids. While peptide secondary metabolites are synthesized by non-ribosomal peptide synthases, using both proteinogenic and non-proteinogenic amino acids (Keller et al. 2005). These few biosynthetic pathways give rise to a wide variety of structurally diverse groups of secondary metabolites.

There has been evidence to support the idea of the transfer of genetic material between both plants and endophytes for the production of certain favourable secondary metabolites (Miller 
1986). For example, metabolites produced by endophytes have also been found in plant hosts. Sumarah et al. (2008) reported that white pine needles which host fungal endophytes contain metabolites produced by the endophyte.

Despite the ubiquity of endophytes in plants, these organisms are known to produce a wide spectrum of secondary metabolites. Little is known concerning their specific roles in defense mechanism. There are however many studies that illustrate the effects of the microbes within their hosts. Mutualistic associations are mediated by the release of secondary metabolites from endophytic fungi which are toxic to pathogens of the host species (Schulz et al. 1995; Schulz et al. 2002).

\subsection{Pathogens and defense mechanisms in higher plants}

\subsubsection{Conifer pathogens}

Many diseases observed in plants arise from fungal origins. The introduction of endophytes into foreign ecosystems can result in deleterious effects on tree hosts. The trees, not having coevolved with these endophytes, are highly susceptible to the pathogenic effects of these microorganisms (Sieber 2007). An example of such pathogens include Cryhonectria parasitica which causes chestnut blight. Eastern white pine, P. strobus, which extends from the Canadian Maritime Provinces to the Great Lakes and down to Mississippi in the US, is the fastest growing pine species and is used extensively in reforestation projects. White pine trees in this region were

once of great economic importance. This industry, however, has suffered severe economic blows, due to the effects of several pathogens. Among the most invasive insects, Pissodes strobi 
(white pine weevil), as well as pathogenic fungi, such as the obligate basidiomycete Cronartium ribicola (white pine blister rust), are widespread in North American forests.

For the past century, white pine species in North America have been plagued by the fungus $C$. ribicola, a fungus native to Asia. C. ribicola causes white pine blister rust and is detrimental to all North American five-needle pines. The first symptoms of infections are needle spotting. The rust then travels into the branches and develops into cankers. Once the fungus girdles a branch, the branch succumbs to its injuries and dies in a few years. Left untreated, the disease can travel to the trunk of the tree and repeats the same pattern as was observed in the branches, resulting in the death of the tree (Maloy 1997).

White pine blister rust is more pervasive in regions of cooler climates and higher levels of humidity (Kreibel 1983). Since the introduction of this rust to our ecosystem, white pine trees have suffered devastating losses, making C. ribicola one of the most important forest pathogens in North American history. This pathogen can infect white pines during all stages of growth; however, younger trees are more susceptible to the disease (Natural Resources Canada 2012). This rust is still very problematic today. In 2010 , almost $70 \%$ of eastern white pine plantations in Quebec were infected with white pine blister rust (Natural Resources Canada 2012). Reforestation efforts have decreased dramatically because of this pathogen.

An older method of disease management involved establishing blister rust hazard zones in reforestation projects. Hazard in this case was defined as zones with higher incidence of stem cankers resulting in a greater possibility of damage from these cankers (Hunt 1983). C. ribicola 
completes its life span by alternating between Ribes spp. (gooseberries and currants) and pine hosts (Et-touil et al. 1999). More recently, due to this dependence of the C. ribicola rust on Ribes spp., much effort has been focused on eliminating these secondary hosts. Consequently, all nonimmune Ribes spp. in close proximity to white pines were eradicated as part of silviculture efforts. Other moderately effective management techniques practiced by foresters include pruning of white pines and the usage of fungicides. An effective treatment against this rust in the US is the fungicide Triadimefon. However, this fungicide has several harmful effects on the environment and has since been categorized as a class C possible human carcinogen (US EPA, 2006). It was observed that in regions of disease incidence, not all trees show signs of infection. Recognizing and planting resistant cultivars was therefore important in maintaining healthy pine stands.

During the period of 2008 to 2011, immune Ribes fields in New Hampshire showed symptoms of white pine blister rust. In 2008, the infection was restricted to one field, however by 2009 , premature defoliation was observed in all Ribes fields in the region. According to Philippe Tanguay (2013), Canadian Forest Service forest pathologist, the genetic fingerprint of this new strain revealed that this rust is a mutation of an already existing strain in the Northeast woods. This virulent strain has yet to be discovered in any other region. Conversely, no study has been conducted to determine if this mutated rust is present in other Ribes fields. Plant pathology and plant-microbe biology professor Kerik Cox estimated that if white pine trees were infected with this mutated strain, it could result in substantial damages to the white pine industry over a period of five to ten years (Frederick et al. 2011). The latest surveillance has shown that approximately $50 \%$ of previously immune Ribes plants (within the New Hampshire region) have succumbed to 
white pine blister rust. Further, the number of infected white pines in the areas surrounding Ribes fields has been steadily increasing (Vermont Invasives 2013). Ribes plants are planted primarily for human consumption. With the prevalence of white pine blister rust, the planting of these species was contingent upon the development of resistant Ribes cultivars. This complication in immunity has therefore created significant implications in forestry and developing Ribes industries. There is a need to identify more adequate and safer methods to decrease the effects of white pine blister rust on white pines.

\subsubsection{Endophytic secondary metabolites and host defense}

All plant types are unremittingly exposed to a wide array of pathogens and have consequently evolved a complex range of defense mechanisms. Congruently, pathogens have also developed the necessary resources to circumvent these defensive tools. Different factors such as plant susceptibility, pathogenic virulence and environmental conditions will collectively influence a pathogens ability to incur disease (Ferreira et al. 2006).

The two most important categories of defense mechanisms employed by plants are described as host-specific and non-specific resistance (Ferreira et al. 2006). Plants can possess the genetic material to resist attacks by a specific pathogen. However, when they do not have the necessary genes or if they occur in levels too low to confer efficient resistance, pathogenic invasions can cause grave damage. A secondary form of resistance involves the interaction between several minor genes to produce a non-specific resistance pattern (Ganley et al. 2008; Terry \& Joyce 2004). 
Endophytes have long been suspected of enhancing defense mechanisms in plants. Today, there is substantial research indicating that fungal secondary metabolites are involved in plants' natural defense systems. Endophyte-mediated or induced resistance has been previously studied and applied in agricultural crops and grasses (Terry \& Joyce 2004). One of the most explicit and well documented demonstrations of the mutualistic behaviour between host plants and endophytes is the beneficial effects of endophytes in cool season grasses. Increased plant growth and reduced insect herbivory were observed in plant hosts (Larkin et al. 2012). The endophytes in tall fescue were later found to produce toxic alkaloids (Ganley et al. 2004) and as a result, the performance of grazing animals decreased when fed endophyte positive grasses, as they suffered intestinal distress or death in some cases (Bacon 1995; Larkin et al. 2012). Clay and Holah (1999), have shown that plots containing endophyte positive $(\mathrm{E}+)$ tall fescue had lower plant diversity over time in comparison to plots of endophyte negative (E-) tall fescue. This was hypothesized to be attributable to the higher competitiveness induced by the endophytes in E+ fescue. Moreover, tall fescues infected with endophytes of the Acremonium family had more desirable morphology in comparison to uninfected fescues (Bacon 1995).

\subsubsection{Endophyte mediated tolerance in conifers}

Today, the mutualism observed between trees and their endophytes is described as being antibiosis in nature. According to Fravel (1988), antibiosis is defined as mediated antagonistic activity through the production of metabolites by microbes. Endophytes isolated and grown in vitro from pine needles are known to produce chemicals that can increase tree fitness. All metabolites isolated from endophytic fungi were produced in vitro with larger fungal biomass compared to that observed in planta. The question therefore became: are these compounds being 
produced in the plants and in sufficient quantities to illicit the same biological effect as that observed in vitro? This question was answered to some degree in a few studies that performed qualitative and quantitative tests to determine the presence of endophytes and the production of a major compound of interest (Ganley et al. 2008; Miller et al. 2002; 2008).

In light of the cyclic epidemics of Choristoneura fumiferana (spruce budworm), during the reanalysis of data obtained from the Green River Project, Royama (1984) considered the different mortality factors of spruce budworms and concluded 5 principal factors: parasitism, predation, food shortage, influence of weather and finally a fifth agent surmised as death caused by complex diseases as well as idiopathic death. Today, this fifth element is taken to be the toxic chemicals produced by conifer endophytes that were influencing the fitness of spruce budworms (Miller 1986).

Endophytes found in superior trees in the Acadian forests (comprising Maine, New Brunswick, Nova Scotia and some areas in eastern Quebec) have been studied extensively dating back to the early 1980's (Miller 2011). Decades of work in the Miller laboratory on conifer foliar endophytes isolated from the Acadian forest has shown antagonistic effects on C. ferana growth attributable to certain endophytes. The metabolite responsible for the antinsectal activity was rugulosin (Figure 1.5). The highly potent hydroxyanthroquinoid rugulosin is typically found in Penicillium rugulosum (Bouhet et al. 1976). However, rugulosin producing endophytes such as Phialocephala scopiformis have been found in red and white spruce trees respectively (Miller et al. 2002). Seedlings inoculated with endophytes of interest, these endophytes were persistent up to 4 years post inoculation. Moreover, when inoculated with endophytes producing rugulosin, the 
metabolite was detectable in pine needles of these young trees in concentrations that can hinder the growth of spruce budworms (Miller et al. 2002; Sumarah et al. 2005). A quantitative PCR method has been developed that can detect an endophyte which produces rugulosin in white spruce trees. Using this analytical method, it was discovered that the endophyte and the metabolite were present in the trees thirteen years post inoculation (Frasz et al. 2014). Other endophytic metabolites that have been isolated during the course of these studies were the known antifungal compounds griseofulvin and pyrenophorol (Figure 1.5). Sumarah et al. (2011) reported the potent antifungal compound pyrenophorol, isolated from the conifer foliar endophyte Lophodermium nitens.

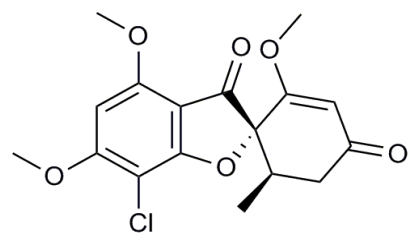

a

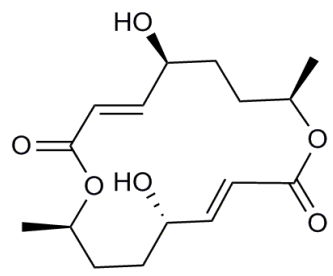

b

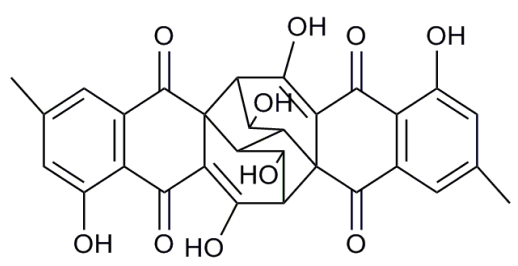

C

Figure 1.5 Examples of beneficial conifer foliar secondary metabolites, griseofulvin (a), pyrenophorol (b) and rugulosin (c).

The native defense mechanism in conifers is not very effective as is observed with the extensive eradication of the species by $C$. ribicola. New methods are therefore necessary to protect white pine trees and allow for greater success rates with reforestation efforts. Since the success in conifers and herbivorous insects has been substantial, researchers have sought for the same success in regards to pathogenic fungi. As mentioned above, not all white pine trees succumbed to the pathogenic effects of $C$. ribicola. Trees in general possess several non-specific defense mechanisms against the attack of fungal pathogens (Ganley et al. 2008). Fungal endophytes are known to be in all conifer species studied to date and are theorized to play a role in the trees' 
natural defense mechanism. There have been studies that illustrate endophytes can increase resistivity in conifers. Ganley et al. (2008) reported that seedlings that were inoculated with specific endophytes isolated from Pinus monticola (western white pine), lived longer and demonstrated greater tolerance toward the symptoms of the pathogen C. ribicola in comparison to seedlings without the endophytes of interest. Furthermore, this quasi resistance was persistent over time.

\subsection{Project Aim}

Decades of research on conifer endophytes have revealed several interesting findings. First, conifer endophytes produce chemicals that can deter the activity of spruce budworms, as well as hinder the growth of the C. ribicola fungus (Miller et al. 2002; Sumarah et al. 2015). Second, it has been shown that conifer seedlings can be inoculated successfully with endophytes (Frasz 2014; Ganley et al. 2008) and that the biologically active secondary metabolites can be expressed in planta at effective concentrations (Miller et al. 2002; Sumarah et al. 2005). Third, the endophytes, once inoculated in seedlings, can be detected over a decade post inoculation (Frasz et al. 2014). Fourth, understory species have been shown to have endophytes that produce bioactive compounds. For example, an undescribed Xylaria endophyte was isolated from white pine needles as well as an understory lowbush blueberry species. Both isolates produced the antifungal compound griseofulvin (Figure 1.5) (Richardson et al. 2014).

This thesis is a continuation of this research, and involved the screening of representative endophytic samples from conifers as well as understory plants is necessary to identify beneficial species. Using previously described methods (Richardson 2014; Sumarah 2008), foliar endophytes were screened for antifungal bioactivity. The secondary metabolites produced by 
selected bioactive strains were then isolated and characterized using different chromatographic, spectrometric and spectroscopic techniques. Purified metabolites were tested for both antimicrobial and antifungal activity. The effectiveness of endophytic strains of interest will be determined by inoculating conifer seedlings.

\section{Materials and Methods}

\subsection{Fermentation}

Conifer endophyte cultures from collections made in New Brunswick were obtained from J. Tanney on Petri dishes with $2 \%$ malt extract agar and were stored at $8^{\circ} \mathrm{C}$. The provenance of each strain is listed in Appendix C. Details on general isolation procedures can be found in Sumarah et al. (2009).

An initial screen was performed to evaluate whether a particular strain produced new or biologically active compounds in vitro. Briefly, a slant of each strain was macerated in sterile $\mathrm{ddH}_{2} \mathrm{O}$ under aseptic conditions. The resulting suspension was used to inoculate $(5 \%, \mathrm{v}: \mathrm{v})$ one Glaxo bottle containing $2 \%$ malt extract. These were incubated for 8 weeks at $25{ }^{\circ} \mathrm{C}$. In this thesis, 89 cultures were screened and 5 were selected for further study. After the screening (see following), the 5 selected cultures were inoculated on a larger scale to facilitate the isolation of potentially new, biologically active compounds.

For larger scale production of culture filtrate extracts, a two-stage fermentation was used. Typically fifteen $250 \mathrm{~mL}$ Erlenmeyer flasks each containing $50 \mathrm{~mL}$ of $2 \%$ malt extract medium 
were inoculated as above. The first stage cultures were allowed to grow for two weeks, macerated under aseptic conditions and individually transferred to Glaxo bottles containing $1 \mathrm{~L}$ of the same medium. These were then incubated for 8 weeks at $25^{\circ} \mathrm{C}$. 


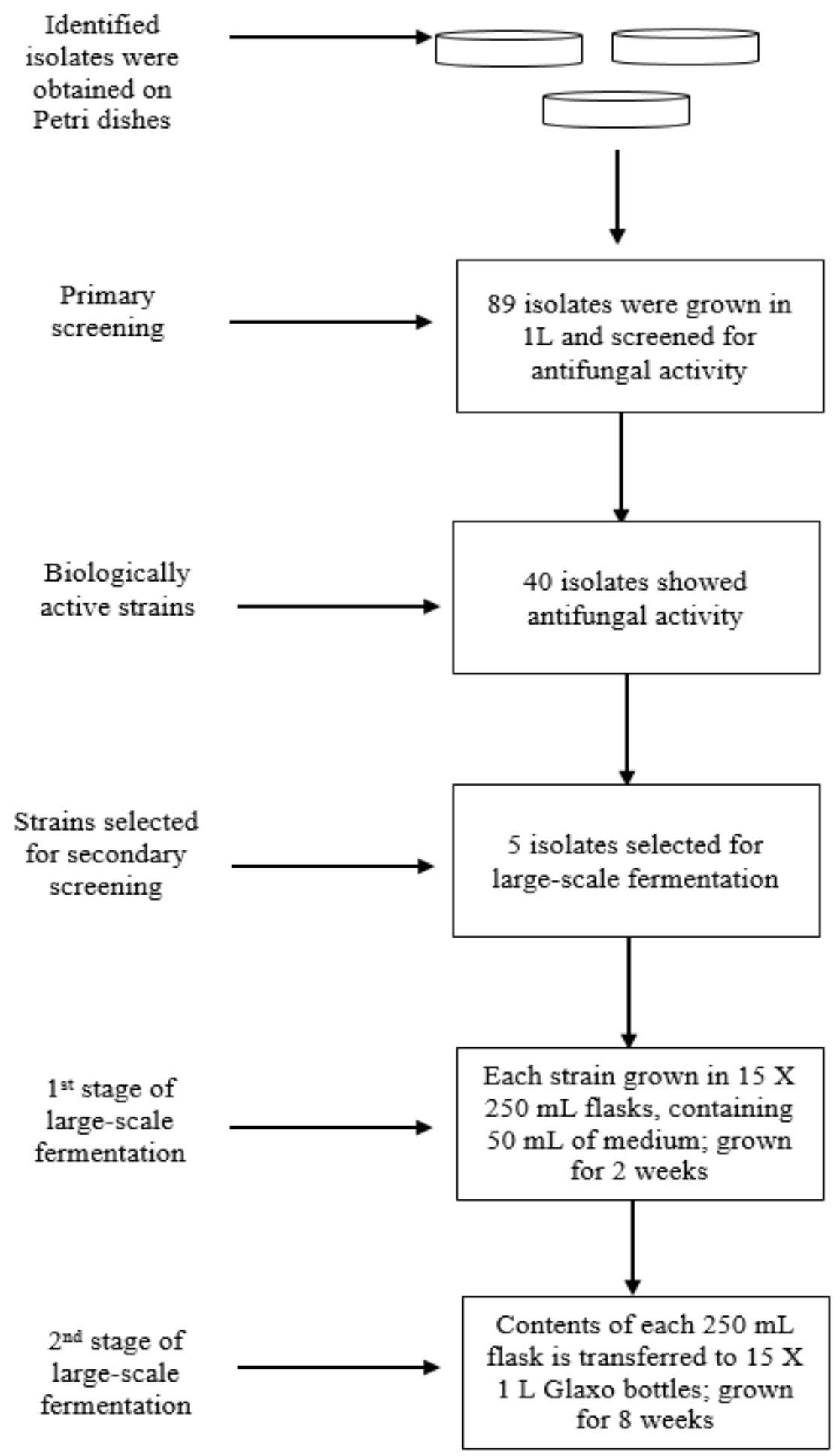

Figure 2.1 An overview of the fermentation process of the fungal strains. 


\subsection{Extraction, isolation and purification of metabolites}

\subsubsection{Extraction}

Mycelium was separated from the culture filtrate by vacuum filtration (using Whatman no. 4 filter papers) and stored at $-24^{\circ} \mathrm{C}$. The culture filtrate broths were exhaustively extracted with ethyl acetate and enough sodium chloride (20-30 g) to saturate the solution. The aqueous layers were discarded and further purification was performed on the organic layer. Anhydrous $\mathrm{Na}_{2} \mathrm{SO}_{4}$ was used to remove remaining water from the organic layer, which was subsequently filtered through Whatman (no. 1) into round bottom flasks. The sample was then concentrated under pressure using a rotary evaporation system. The crude filtrate extracts were pooled, taken up in a minimal amount of methanol (1-3 mL) in pre-weighed vials and dried under a gentle stream of nitrogen. The weight of the samples were then recorded.

\subsubsection{Analysis}

After extraction, each sample was re-dissolved in 2-3 $\mathrm{mL}$ of methanol and filtered (using $0.2 \mu \mathrm{m}$ syringe filters) into clean vials. Aliquots were then analyzed via reversed-phase (RP) LC-UVMS, using Waters 2795 separations module, Waters 996 diode array detector and Micromass Quattro LC mass spectrometer, on a C18 100A column (100 x 4.60 mm, $2.6 \mu \mathrm{m}$; Phenomenex Kinetex), (Torrance, CA, USA). Samples were eluted with a mobile phase consisting of acetonitrile-water $\left(\mathrm{ACN}-\mathrm{H}_{2} \mathrm{O}\right)$ with formic acid $0.1 \%$, (v/v). 
All bulk crude samples were separated by column chromatography or flash chromatography using gradient systems (hexanes to $(5-100 \%)$ ethyl acetate, then ethyl-acetate to $(5-50 \%)$ methanol). Fractions were dried under pressure and transferred to pre-weighed vials. Column fractions were then screened by RPLC-UV-MS and screened in in the Oxford disk bioassay (described below). Further purification was achieved by semi-preparative RP-HPLC using an Agilent 1100 HPLC system equipped with a diode array detector and compounds were separated by a C18 100A column (250 x $10 \mathrm{~mm}, 5 \mu \mathrm{m}$; Phenomenex Luna) (SUPELCO, St Louis, Missouri). The solvent gradient was linear programmed from 5 to $100 \%$ acetonitrile over $15-25$

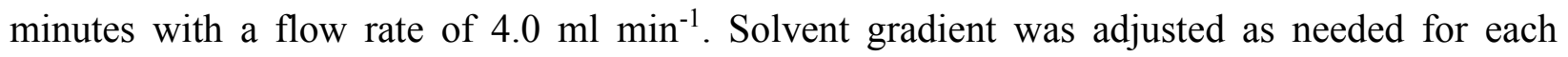
fraction.

Individual fractions were then analyzed by LC-UV-MS, and further characterization was carried out via NMR analysis. Each compound was dissolved in $600 \mu \mathrm{L}$ of methyl alcohol- $\mathrm{d}_{4}\left(\mathrm{CD}_{3} \mathrm{OD}\right)$ for $1 \mathrm{D}$ and 2D NMR experiments $\left({ }^{1} \mathrm{H},{ }^{13} \mathrm{C}\right.$, HSQC, HMBC, COSY, DEPT135 and NOESY). COSY correlations were used to deduce closely bonding protons; NOESY provides information on protons that are within the same spatial planes; HSQC shows the protons that are directly bonded to specific carbons, and HMBC shows carbons that are close enough to protons through bonds. These were performed on a Bruker Avance III $400.13\left({ }^{1} \mathrm{H}\right)$ and $100 \mathrm{MHz}\left({ }^{13} \mathrm{C}\right)$ spectrometer, using a $5 \mathrm{~mm}$ auto-tuning broadband probe with a Z-gradient. Spectroscopic data were referenced to the $\mathrm{CD}_{3} \mathrm{OD}$ solvent peak at $\delta_{\mathrm{H}} 3.31$ and at $\delta_{\mathrm{C}} 49.1$. Further characterization methods involved the measurement of the optical rotations and the UV-vis absorption. UV spectra were obtained on a Varian Cary 3 UV-visible spectrophotometer scanning from 800-200 
nm. Optical rotations were measured using an Autopol IV polarimeter (Rudolph Analytical, Hackettown).

HRMS and HRMS ${ }^{2}$ analysis were performed on a Thermo Scientific Q-Exactive Quadrupole Orbitrap Mass Spectrometer, coupled to an Agilent 1290 HPLC system. Two $\mu \mathrm{L}$ of each sample were injected onto a Zorbax Eclipse Plus RRHD C18 column (2.1 x 50 mm, $1.8 \mu \mathrm{m}$; Agilent) maintained at $35^{\circ} \mathrm{C}$. Samples were separated using a flow rate of $0.3 \mathrm{~mL} \mathrm{~min}^{-1}$ with a mobile phase of water with $0.1 \%$ formic acid (A), and acetonitrile with $0.1 \%$ formic acid (B). Mobile phase B was held at $0 \%$ for 30 seconds, before increasing to $100 \%$ over three minutes. B was then held at $100 \%$ for 1 minute before returning to $0 \%$ over 30 seconds. The following conditions were used for HESI: capillary temperature, $400^{\circ} \mathrm{C}$; sheath gas, 17 units; auxiliary gas, 8 units; probe heater temperature, $450{ }^{\circ} \mathrm{C}$; S-Lens RF level, 45 . A capillary voltage was $3.9 \mathrm{kV}$ and $3.7 \mathrm{kV}$ for positive and negative mode respectively. Full MS was acquired in negative mode using the following settings: scan range, $m / z 75$ - 1125; resolution, 17 500; AGC, 5e5; max IT, $60 \mathrm{~ms} . \mathrm{MS}^{2}$ spectra were acquired using a $1.0 \mathrm{~m} / \mathrm{z}$ isolation window at collision energies of $10,20,30,35$, and 50 NCE.

\subsection{Biological activity assays}

The Oxford disk diffusion assay (Vincent \& Vincent 1944) was used for preliminary screening for antifungal activity of the crude extracts. Solutions were made at concentrations of $50 \mathrm{mg} \mathrm{mL}^{-}$

${ }^{1}$ in methanol. Nystatin was used as a positive control at a concentration of $1 \mathrm{mg} \mathrm{mL}^{-1} .10 \mu \mathrm{L}$ of 
each sample was transferred to $10 \mathrm{~mm}$ sterilized discs. 4 discs were placed on sterilized $2 \%$ malt extract and $1.8 \%$ agar plates and stored in an incubator at $25^{\circ} \mathrm{C}$.

All purified compounds were tested for in vitro antifungal and antibacterial activity against the biotrophic fungal pathogen Microbotryum violaceum, which serves as a proxy to C. ribicola, a representative yeast Saccharomyces cerevisiae, as well as Bacillus subtilis (ATCC 23857) and Escherichia coli (DH $)$. M. violaceum was grown in $20 \mathrm{~g} \mathrm{~L}^{-1}$ malt extract, $2.5 \mathrm{~g} \mathrm{~L}^{-1}$ peptone and $2.5 \mathrm{~g} \mathrm{~L}^{-1}$ yeast extract whereas $S$. cerevisiae was inoculated and grown in $1 \mathrm{~g} \mathrm{~L}^{-1}$ yeast extract supplemented with $10 \mathrm{~g} \mathrm{~L}^{-1}$ glucose. The yeast medium was inoculated with $0.25 \mathrm{~g} \mathrm{~L}^{-1}$ of Fleishmann's yeast. Bacteria were inoculated and grown in $5 \mathrm{~g} \mathrm{~L}^{-1}$ yeast extract, $10 \mathrm{~g} \mathrm{~L}^{-}$ ${ }^{1}$ peptone, and $10 \mathrm{~g} \mathrm{~L}^{-1} \mathrm{NaCl}$. Chloramphenicol and nystatin were used as respective positive controls; DMSO was the negative control. Compounds were individually tested in triplicates at 5, 50 and $500 \mu \mathrm{M}$ in sterile 96-well microplates. Each metabolite was dissolved in DMSO and a $10 \mu \mathrm{L}$ aliquot of each solution was added to $200 \mu \mathrm{L}$ of bacterial or fungal suspension. The plates were incubated at $28^{\circ} \mathrm{C}$ on a shaker, providing gentle agitation (500-700 rpm). Optical density (OD) measurements were made at $600 \mathrm{~nm}$ with a Molecular Devices Spectra Max 340 reader, microplate spectrophotometer, 94089 (Sunnyvale, CA, USA). Antimicrobial OD data were analyzed by ANOVA followed by Tukey's test for significant differences (Systat V12) compared to the negative control (DMSO). 


\section{Results}

Following a display of antifungal activity against $S$. cerevisiae and $M$. violaceum, 3 endophytic strains were selected from large-scale fermentation: Lachnum papyraceum (NB-175-2) DAOMC 250335, Seimatosporium sp. (affin. S. foliicola, NB330) DAOMC 250336 and Diaporthe celastrina (AW 545) DAOMC 250334. Strains were selected based on their chemical profiles determined by their LC-UV-MS chromatograms, the novelty of the strains to the Miller group and in some cases, the weight of the extract obtained from the culture filtrate following the screening fermentation. All LC-UV-MS were determined in $\mathrm{ESI}^{+}$unless otherwise specified.

\subsection{Secondary metabolites from the Lachnum papyraceum strain}

Following the extraction of the bulk fermentation of L. papyraceum with EtOAc, the weight of the culture filtrate extract was $1.92 \mathrm{~g}$. Column chromatography was used to separate the extract into 11 fractions, having a percent recovery of $95 \%$. The fractions were then screened using the Oxford Assay. Seven fractions demonstrated bioactivity; fractions 1 to 5 showed activity against $S$. cerevisiae, while fractions 1 to 6 as well as 8 had activity against $M$. violaceum. These fractions were further purified using semi-preparative HPLC. A total of 4 compounds were identified from this strain.

Fraction 1 had a weight of $215 \mathrm{mg}$ and was dissolved in $4 \mathrm{~mL}$ of HPLC grade MeOH. The HPLC method employed for the separation of this fraction included a solvent system ranging from 25$100-25 \%$ ACN over 25 minutes at a flow rate of $4 \mathrm{~mL}_{\text {minute }}{ }^{-1}$. A total of $50 \mu \mathrm{L}$ of the solution was injected per run. Seven peaks were observed in the HPLC chromatogram. Peaks 1, 3 and 5 were purified and identified as compounds 1, 2 and 3 respectively. Fraction 3 of this extract 
filtrate had a weight of $106 \mathrm{mg}$ and was dissolved in $3 \mathrm{~mL}$ of HPLC MeOH. A similar HPLC method was used and 10 peaks were observed in its chromatogram. Peak 9 was purified and from this, compound 4 was obtained.

\section{Compound 1}

Compound 1 was isolated as a pale yellow oil, with a weight of $5.0 \mathrm{mg}$. The UV maximum was found at 216. ESI-MS data showed the $m / z 248.98[\mathrm{M}+\mathrm{H}]{ }^{+}$. Other major peaks in the chromatogram were $m / z 290.05[\mathrm{M}+\mathrm{ACN}]^{+}, m / z 519.15[2 \mathrm{M}+\mathrm{Na}]$, as well as the $m / z 230.99$ $\left[\mathrm{M}-\mathrm{H}_{2} \mathrm{O}\right]^{+}$and the $m / z 266.97\left[\mathrm{M}+\mathrm{H}_{2} \mathrm{O}\right]^{+}$. The empirical formula was deduced as $\mathrm{C}_{14} \mathrm{H}_{16} \mathrm{O}_{4}$, giving an exact mass of 248.1049. The experimental mass was obtained via HRMS as the $\mathrm{m} / \mathrm{z}$ $249.1121[\mathrm{M}+\mathrm{H}]^{+}$, at r.t. $2.95 \mathrm{~min}$. and a mass error of $-0.036 \mathrm{ppm}$. The unit of unsaturation calculated was 7 .

The ${ }^{1} \mathrm{H}$ NMR spectrum displayed one aromatic proton at $\delta 6.78$ (s) as well as two low-field protons at $\delta 6.36(\mathrm{dp}, J=11.9,1.5 \mathrm{~Hz})$ and $\delta 6.25(\mathrm{dq}, J=11.9,7.1 \mathrm{~Hz})$ located on the olefinic carbons at $\delta 122.9$ and $\delta 137.6$, respectively. COSY correlations were sequentially observed between these methine protons at $\delta 6.36$ and $\delta 6.25$ and the methyl protons at $\delta 1.90$. Additional COSY correlations were observed between a methine proton at $\delta 2.23(\mathrm{dd}, J=8.3,5.6 \mathrm{~Hz})$ and the inequivalent methylene signals at $\delta 1.81(\mathrm{dd}, J=8.2,4.6 \mathrm{~Hz})$ and $\delta 1.57(\mathrm{dd}, J=5.6,4.6 \mathrm{~Hz})$. The difference in shifts of these geminal protons was indicative of a $\mathrm{CH}_{2}$ in a ring.

The ${ }^{13} \mathrm{C}$ NMR spectrum show characteristic carbons that identified two carboxylate groups that were determined to be located para to each other at $\delta 195.8$ and $194.5 \mathrm{ppm}$. Four carbons with the following shifts $\delta 137.4,147.3,122.9$ and 137.6 were indicative of carbon-carbon double 
bonds. It was deduced that one double bond was located within a six-membered ring, while the second $\mathrm{C}=\mathrm{C}$ was located in a 1', 2' - ethylene $-2^{\prime}-(\mathrm{Me})$ moiety (Figure 3.1). A single methylene with a shift of $\delta 14.4$ was present in the molecule. NMR data are reported in Table 3.1. Compound $\mathbf{1}$ was identified as ( 1 'Z)-dechloromycorrhizin A, which was previously reported by Stadler and Anke (1995) from the same fungus. The $J$ coupling of $11.9 \mathrm{~Hz}$ between the protons $\delta 6.36$ and $\delta 6.25$ were used to distinguish between this compound and its isomer (l'E)dechloromycorrhizin A. The mass spectrometry and spectroscopic data were comparable to the literature values (Stadler et al. 1995).

\section{Compound 2}

Compound 2 was isolated as a yellow oil with a weight of $9.6 \mathrm{mg}$. The UV maxima were 231 and $301 \mathrm{~nm}$. Major peaks observed in ESI-MS were $m / z 324.07[\mathrm{M}+\mathrm{ACN}]^{+}, m / z$ of $326.09[\mathrm{M}$ $+\mathrm{ACN}+2]^{+}, m / z 282.98[\mathrm{M}+\mathrm{H}]^{+}$and the $m / z 285.01[\mathrm{M}+\mathrm{H}+2]^{+}$. These isotopic peak profiles indicate the presence of a single chlorine atom in the molecule. The molecular formula for compound 2 was found to be $\mathrm{C}_{14} \mathrm{H}_{15} \mathrm{O}_{4} \mathrm{Cl}$, with an exact mass of 282.0659 and an experimental mass of 283.0733 obtained from HRMS as the $[\mathrm{M}+\mathrm{H}]^{+}$with an r.t. of $2.95 \mathrm{~min}$. and a mass error of $0.44 \mathrm{ppm}$. The unit of unsaturation calculated for this compound was 7 .

Similarities in ${ }^{1} \mathrm{H}$ and ${ }^{13} \mathrm{C}$ NMR shifts indicated that compounds $\mathbf{1}$ and $\mathbf{2}$ were structurally related. The ${ }^{1} \mathrm{H}$ NMR spectra displayed two low field protons at $\delta 6.94$ and $\delta 6.98$. Contrary to compound 1, a third proton resonance was not observed in this region. A COSY correlation was observed between the methine at $\delta 6.94(\mathrm{q}, J=7.0)$ and the methyl at $\delta 2.02(\mathrm{~d}, J=6.9)$. This 
correlation confirms the absence of the proton observed in compound $\mathbf{1}$ at C 1' (see Table 3.1) and its substitution with a $\mathrm{Cl}$ atom. All remaining proton shifts were also observed in compound 1.

${ }^{13} \mathrm{C}$ NMR shifts suggested para carbonyl groups similar to those in compound $\mathbf{1}$ at $\delta 193.7$ and $\delta$ 194.3. Also observed was the presence of similar geminal methyl groups at $\delta 25.3$ and 29.2, both having singlet proton shifts of $\delta 1.31$ and 1.21 respectively.

Similar coupling data were observed for both compounds $\mathbf{1}$ and $\mathbf{2}$; the main difference being the substitution of a $\mathrm{Cl}$ atom on $\mathrm{C}$ 1' (see Figure 3.1). Compound 2 was identified as mycorrhizin A by Trofast and Wickberg (1977) and was isolated from a mycorrhizal fungus of Monotropa hypopitys. The spectroscopic data for compound 2 were comparable to those found in the literature (Trofast \& Wickberg 1977).

\section{Compound 3}

Compound $3(25.9 \mathrm{mg})$ was isolated as a yellow oil and had UV (MeOH) maxima at 247 and $304 \mathrm{~nm}$. EI-MS peaks observed were the $m / z 317.01[\mathrm{M}+\mathrm{H}]^{+}$and the $m / z 319.01[\mathrm{M}+\mathrm{H}+2]^{+}$. Isotopic patterns indicating the presence of two $\mathrm{Cl}$ atoms in the molecule were observed. Other major peaks in the spectrum were the sodiated peaks at $m / z 340.07[\mathrm{M}+\mathrm{H}+\mathrm{Na}]^{+}$and the $m / z$ $341.99[\mathrm{M}+\mathrm{H}+2+\mathrm{Na}]^{+}$. The molecular formula was $\mathrm{C}_{14} \mathrm{H}_{14} \mathrm{O}_{4} \mathrm{Cl}_{2}$, with an exact mass of 
316.0269. HRMS showed the experimental mass of this compound at $m / z 317.0342[\mathrm{M}+\mathrm{H}]^{+}$, with a mass error of $0.16 \mathrm{ppm}$. The unit of unsaturation calculated for this compound was 7 .

${ }^{1} \mathrm{H}$ and ${ }^{13} \mathrm{C}$ NMR shifts were similar to those of compounds $\mathbf{1}$ and $\mathbf{2}$, with the sole exception being the presence of a single low-field proton at $\delta 6.03(\mathrm{q}, J=6.7 \mathrm{~Hz}$ ) (see Table 3.1). COSY correlations were observed between the protons on C 2' and C 3': $\delta 6.03(\mathrm{q}, J=6.7 \mathrm{~Hz})$ and $\delta$ $1.94(\mathrm{q}, J=6.7 \mathrm{~Hz})$ (Table 3.1). The proton in compounds 1 and 2 located on C 3, was not present in this molecule, which agrees with the above data of there being an additional $\mathrm{Cl}$ atom. The physical and chemical data here was comparable to that in Trofast and Wickberg (1977).

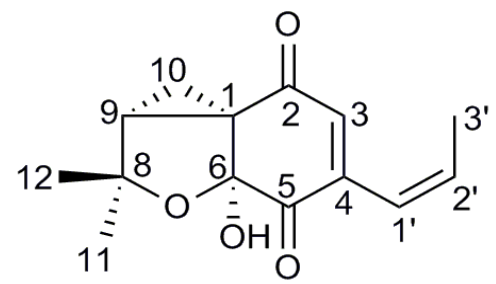

1<smiles></smiles>

2<smiles></smiles>

3

Figure 3.1 The structures of compounds 1-3: (1'Z)-dechloromycorrhizin A (1), mycorrhizin A (2) and chloromycorrhizin A (3). 
Table 3.1 Comparative ${ }^{1} \mathrm{H}$ and ${ }^{13} \mathrm{C}$ NMR data of compounds 1-3 (400.13 MHz, $\left.\mathrm{CD}_{3} \mathrm{OD}\right)$.

\begin{tabular}{|c|c|c|c|c|c|c|}
\hline \multirow{2}{*}{ Position } & \multicolumn{2}{|c|}{ Compound 1} & \multicolumn{2}{|c|}{ Compound 2} & \multicolumn{2}{|c|}{ Compound $\mathbf{3}$} \\
\hline & $\delta_{\mathrm{C}}$, type & $\delta_{\mathrm{H}}(J$ in $\mathrm{Hz})$ & $\delta_{\mathrm{C}}$, type & $\delta_{\mathrm{H}}(J$ in $\mathrm{Hz})$ & $\delta_{\mathrm{C}}$, type & $\delta_{\mathrm{H}}(J$ in $\mathrm{Hz})$ \\
\hline 1 & 43.9 & & 44.1 & & 43.5 & \\
\hline 2 & 194.5 & & 194.3 & & 186.7 & \\
\hline 3 & $137.4, \mathrm{CH}$ & $6.78, \mathrm{~s}$ & $137.8, \mathrm{CH}$ & $6.98, \mathrm{~s}$ & 146.7 & \\
\hline 4 & 147.3 & & 147.3 & & 145.7 & \\
\hline 5 & 195.8 & & 193.7 & & 191.3 & \\
\hline 6 & 101.3 & & 102.8 & & 101.5 & \\
\hline 8 & 82.6 & & 83.1 & & 82.9 & \\
\hline 9 & $45.1, \mathrm{CH}$ & $\begin{array}{c}2.23, \mathrm{dd} \\
(8.3,5.6)\end{array}$ & $45.2, \mathrm{CH}$ & $\begin{array}{c}2.26, \mathrm{dd} \\
(8.2,5.8)\end{array}$ & $46.3, \mathrm{CH}$ & $\begin{array}{l}2.37, \mathrm{dd} \\
(8.3,5.9)\end{array}$ \\
\hline 10 & 14.4, $\mathrm{CH}_{2}$ & $\begin{array}{c}1.81, \mathrm{dd} \\
(8.2,4.6)\end{array}$ & $15.5, \mathrm{CH}_{2}$ & $\begin{array}{c}1.78, \mathrm{dd} \\
(8.2,4.6)\end{array}$ & 15.6, $\mathrm{CH}_{2}$ & $\begin{array}{c}1.91, \mathrm{dd} \\
(8.3,4.7)\end{array}$ \\
\hline & & $\begin{array}{c}1.57, \mathrm{dd} \\
(5.6,4.6)\end{array}$ & & $\begin{array}{c}1.59, \mathrm{dd} \\
(5.8,4.6)\end{array}$ & & $\begin{array}{c}1.68, \mathrm{dd} \\
(5.9,4.7)\end{array}$ \\
\hline 11 & $25.1, \mathrm{CH}_{3}$ & $1.30, \mathrm{~s}$ & $25.3, \mathrm{CH}_{3}$ & $1.31, \mathrm{~s}$ & $25.0, \mathrm{CH}_{3}$ & $1.30, \mathrm{~s}$ \\
\hline 12 & $29.2, \mathrm{CH}_{3}$ & $1.18, \mathrm{~s}$ & $29.2, \mathrm{CH}_{3}$ & $1.21, \mathrm{~s}$ & $29.2, \mathrm{CH}_{3}$ & $1.19, \mathrm{~s}$ \\
\hline $1 '$ & $122.9, \mathrm{CH}$ & $\begin{array}{c}6.36, \mathrm{dq} \\
(11.9,1.5)\end{array}$ & 128.3 & & 123.7 & \\
\hline $2^{\prime}$ & 137.6, CH & $\begin{array}{c}6.25, \mathrm{dq} \\
(11.9,7.1)\end{array}$ & $137.8, \mathrm{CH}$ & $\begin{array}{c}6.94, \mathrm{q} \\
(7.0)\end{array}$ & $131.8, \mathrm{CH}$ & $\begin{array}{c}6.03, \mathrm{q} \\
(6.7)\end{array}$ \\
\hline $3^{\prime}$ & $15.8, \mathrm{CH}_{3}$ & $\begin{array}{c}1.90, \mathrm{dd} \\
(7.1,1.7)\end{array}$ & $16.2, \mathrm{CH}_{3}$ & $\begin{array}{c}2.02, \mathrm{~d} \\
(6.9)\end{array}$ & $14.3, \mathrm{CH}_{3}$ & $\begin{array}{c}1.94, \mathrm{~d} \\
(6.7)\end{array}$ \\
\hline
\end{tabular}

\section{Compound 4}

Compound 4 was isolated as a bright yellow oil and had a weight of $6.0 \mathrm{mg}$. UV (MeOH) maxima were measured as 206 and $269 \mathrm{~nm}$. The major peaks observed in the ESI-MS spectrum were similar to those of compound 3, $m / z 317.00[\mathrm{M}+\mathrm{H}]^{+}$and $m / z 318.99[\mathrm{M}+\mathrm{H}+2]^{+}$. Additional peaks included the $\left[\mathrm{M}-\mathrm{H}_{2} \mathrm{O}\right]^{+}$at an $m / z$ of 298.10 as well as $[\mathrm{M}-\mathrm{HCl}]^{+}$peak at $m / z$ 
281.04. The molecular formula was $\mathrm{C}_{14} \mathrm{H}_{14} \mathrm{O}_{4} \mathrm{Cl}_{2}$, with an exact mass of 316.0269 and an experimental mass as $[\mathrm{M}+\mathrm{H}]$ of 317.0344 with a mass error of 0.73 .

From interpretation of the NMR spectra of compound 4, it appears to be related to compound 3 . The ${ }^{1} \mathrm{H}$ NMR spectrum displayed the same number of protons as that of compound $\mathbf{3}$, (see Table 3.2). COSY correlations were observed between a methine proton at $\delta 5.95(\mathrm{q}, J=6.7 \mathrm{~Hz})$ and the methyl protons (see $\mathrm{C} 3^{\prime}$ in Figure 3.2) at a $\delta 1.91(\mathrm{~d}, J=6.7 \mathrm{~Hz}$ ). The second methine proton at $\delta 3.78(\mathrm{t}, J=5.1 \mathrm{~Hz})$ showed COSY correlations to the vicinal protons located on the methylene group $(\delta 26.5)$ with shifts at $\delta 2.48(\mathrm{dd}, J=18.5,5.2 \mathrm{~Hz})$ and $2.70(\mathrm{dd}, J=18.4,4.9$ Hz). From the proposed structure in Figure 3.2, the proton at $\delta 3.78$ should have a doublet of doublets splitting pattern. The triplet that was observed can be attributed to poor resolution due to overlapping of the peaks. The remaining protons in this compound were singlet methyls at $\delta$ 1.33 and $\delta 1.38$.

There were key differences in the ${ }^{1} \mathrm{H}$ spectroscopic data such as the increase observed in the ${ }^{1} \mathrm{H}$ chemical shift at $\delta 3.78(\delta 2.23-\delta 2.37$; C 9, see Table 3.1).This increase in chemical shift in compound $\mathbf{4}$ is indicative of a geminal electron withdrawing group such as a hydroxyl group being present. Additionally, the increase in the methylene protons to shifts of $\delta 2.70$ and $\delta 2.48$ (from $\delta 1.57-\delta 1.91$ on C 10 , see Table 3.1), as well as the increase observed in the $J$ coupling (from 4.6 and $4.7 \mathrm{~Hz}$ to $18.4 \mathrm{~Hz}$ ) indicates that a cyclopropane ring is no longer present. Ring strain introduced by the cyclopropane in compounds $\mathbf{1 - 3}$ would have a positive effect on geminal coupling (coupling would be lower) and would consequently lower the chemical shifts. This increase in $\mathrm{Hz}$ would therefore suggest that these inequivalent methylene protons have been incorporated in a less constrained ring such as a cyclohexane. 
Fourteen carbons were present in the ${ }^{13} \mathrm{C}$ NMR spectrum. HSQC and DEPT-135 showed 3 methyls, 1 methylene and two methines. Differences in the ${ }^{13} \mathrm{C}$ spectra included the two keto groups at lower chemical shifts at $\delta 178.3$ and $\delta$ 179.9. Furthermore, HMBC correlations from the methylene protons on $\mathrm{C} 10$ would indicate that the quaternary carbons at $\delta 117.0$ and $\delta 153.2$ were in a similar environment to the carbons at $\delta 43.5$ and $\delta 101.5$ in compound 3. As these carbons are now located more low-field, it is likely that they now form a carbon-carbon double bond. This would corroborate with the disappearance of the cyclopropane and cyclopentane rings observed in the 3 first compounds (Figure 3.1). This addition of a $5^{\text {th }}$ double bond would satisfy the unsaturation index of 7. The methine group at $\delta 68.4$ is in a similar environment (see Table 3.2 for HMBC data) as the methine in compound 3, at $\delta$ 46.3. This higher shift indicates that a hydroxyl group is now bonded to this carbon as was mentioned above.

Relative stereochemistry was determined by NOESY and a previously established configuration. Compounds 1-3 possess identical stereochemistry. This was first established by Grove (1985) using X-ray crystallography. Consequently, no detailed spectroscopic data was presented for the stereochemistry of these mycorrhizins. Later in Stadler et al. (1995), NOESY information was presented for a related compound, papyracon A (Figure 3.4). For compound 4, a single NOESY correlation was observed between the methyl protons at $\delta 1.33$ (C 12 in Figure 3.2) and the methine proton at $\delta 3.78$ (on C 9 in Figure 3.2). This NOESY correlation provides conclusive information that this methyl and proton are in the same plane. From the literature concerning these mycorrhizin derived compounds, the stereochemistry at C 8 is typically the same. Going from this, it was suggested that compound $\mathbf{4}$ would have a similar configuration at this carbon. NOESY correlations observed for papyracon A suggested that the proton at $\delta 3.78$ (on C 9) was also in the same plane as the methyl group at $\mathrm{C} 12$. Due to the presence of the methylene (C 10) 
adjacent to the methine at $\mathrm{C} 9, J$ coupling values can also be considered. In a cyclic system, the order of $J$ values is: $J_{\text {geminal }}>J_{\text {trans }}>J_{\text {cis }}$ (Pavia et al. 2001). Based on this, the protons at $\delta 2.70$ (dd, $J=18.4,4.9)$ and $\delta 2.48(\mathrm{dd}, J=18.5,5.2)$ are characterized as $\mathrm{H} \alpha$ and $\mathrm{H} \beta$ respectively, with $\mathrm{H} \alpha$ being in the same plane as $\mathrm{C}$ 9-H due to the slightly lower $J$ value.

The structure below in (Figure 3.2) was proposed based on HMBC and COSY correlations. This compound is reported for the first time.

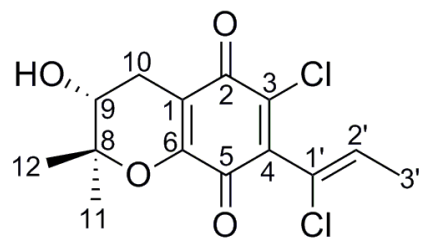

Figure 3.2 Compound 4, 3-chloro-4-[(1Z)-1'-chloroprop-1'-en-1'-yl]-9-hydroxy-8,8-dimethyl-

9, 4,5,8-tetrahydro-2H-1-benzopyran-5,2-dione.

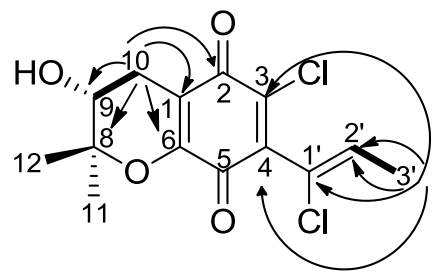

Figure 3.3 Key HMBC and COSY correlations observed for compound 4.

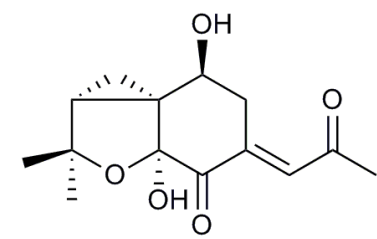

Figure 3.4 A related compound, papyracon A. 
Table 3.2 ${ }^{1} \mathrm{H}$ and ${ }^{13} \mathrm{C}$ NMR data for compound $4\left(400.13 \mathrm{MHz}, \mathrm{CD}_{3} \mathrm{OD}\right)$.

\begin{tabular}{|c|c|c|}
\hline & & \\
\hline Position & $\delta_{\mathrm{C}}$, type & $\delta_{\mathrm{H}}(J$ in $\mathrm{Hz})$ \\
\hline
\end{tabular}

\begin{tabular}{|c|c|c|c|c|}
\hline 1 & 117.0 & & & \\
\hline 2 & 179.9 & & & \\
\hline 3 & 140.8 & & & \\
\hline 4 & 122.8 & & & \\
\hline 5 & 178.3 & & & \\
\hline 6 & 153.2 & & & \\
\hline 8 & 82.6 & & & \\
\hline 9 & $68.4, \mathrm{CH}$ & $3.78, \mathrm{t}(5.1)$ & $22.1,25.0,117.0$ & $2.48,2.70$ \\
\hline \multirow[t]{2}{*}{10} & $26.5, \mathrm{CH}_{2}$ & $2.48, \mathrm{dd}(18.5,5.2)$ & $\begin{array}{c}68.4,82.6,117.0,153.2 \\
179.9\end{array}$ & $2.70,3.78$ \\
\hline & & $2.70, \mathrm{dd}(18.4,4.9)$ & $\begin{array}{c}68.4,82.6,117.0,153.2 \\
179.9\end{array}$ & $2.48,3.78$ \\
\hline 11 & $22.1, \mathrm{CH}_{3}$ & $1.38, \mathrm{~s}$ & $25.0,68.4,82.6$ & \\
\hline 12 & 25.0, $\mathrm{CH}_{3}$ & $1.33, \mathrm{~s}$ & $22.1,68.4,82.6$ & \\
\hline 1 ' & 143.5 & & & \\
\hline $2^{\prime}$ & 131.6, $\mathrm{CH}$ & $5.95, q(6.7)$ & $14.3,122.8,140.8$ & 1.91 \\
\hline $3^{\prime}$ & $14.3, \mathrm{CH}_{3}$ & $1.91, \mathrm{~d}(6.7)$ & $\begin{array}{c}122.8,131.6,140.8,143.5 \\
178.3\end{array}$ & 5.95 \\
\hline
\end{tabular}


Table 3.3 Summary of the physico-chemical properties of the L. papyraceum compounds.

\begin{tabular}{|c|c|c|c|c|}
\hline Properties & 1 & 2 & 3 & 4 \\
\hline Appearance & pale yellow oil & yellow oil & yellow oil & bright yellow oil \\
\hline $\begin{array}{l}\text { Empirical } \\
\text { formula }\end{array}$ & $\mathrm{C}_{14} \mathrm{H}_{16} \mathrm{O}_{4}$ & $\mathrm{C}_{14} \mathrm{H}_{15} \mathrm{O}_{4} \mathrm{Cl}$ & $\mathrm{C}_{14} \mathrm{H}_{14} \mathrm{O}_{4} \mathrm{Cl}_{2}$ & $\mathrm{C}_{14} \mathrm{H}_{14} \mathrm{O}_{4} \mathrm{Cl}_{2}$ \\
\hline \multicolumn{5}{|l|}{$\begin{array}{l}\text { ESI-MS }(m / z) \\
\text { or }\end{array}$} \\
\hline $\begin{array}{l}\operatorname{HRMS}(m / z) \\
\text { Experimental } \\
\text { mass }\end{array}$ & $249.1121[\mathrm{M}+\mathrm{H}]^{+}$ & $283.0733[\mathrm{M}+\mathrm{H}]^{+}$ & $317.0342[\mathrm{M}+\mathrm{H}]^{+}$ & $317.0344[\mathrm{M}+\mathrm{H}]^{+}$ \\
\hline Calculated mass & 248.1049 & 282.0659 & 316.0269 & 316.0269 \\
\hline $\mathrm{OR}[\alpha]_{D}^{T}$ & $\begin{array}{l}{[\alpha]_{D}^{23.9}+4.2^{\circ}(c} \\
\left.0.24,\left(\mathrm{CH}_{3}\right)_{2} \mathrm{CO}\right)\end{array}$ & $\begin{array}{c}{[\alpha]_{D}^{24.1}+4.8^{\circ}(c} \\
0.46, \mathrm{EtOH})\end{array}$ & $\begin{array}{c}{[\alpha]_{D}^{24.1}-33.8^{\circ}(c} \\
1.20, \mathrm{EtOH})\end{array}$ & $\begin{array}{c}{[\alpha]_{D}^{23.1}+10.6^{\circ}(c} \\
0.30, \mathrm{MeOH})\end{array}$ \\
\hline $\begin{array}{l}\mathrm{UV}(\mathrm{MeOH}) \\
\lambda_{\max } \mathrm{nm}(\log \varepsilon)\end{array}$ & $\begin{array}{c}216(3.76) ; \\
\\
\text { literature: } 218 \\
\text { (3.97) (Stadler \& } \\
\text { Anke 1995) }\end{array}$ & $\begin{array}{c}231(3.97), 301 \\
(3.88) ; \\
\text { literature:229 } \\
\text { (3.63), } 298(2.58) \\
\text { (Trofast and } \\
\text { Wickberg 1976) }\end{array}$ & $\begin{array}{c}247 \text { (3.94), } 304 \\
(3.35) ; \\
\text { literature: } 246 \\
\text { (3.90), } 305 \text { (3.24) } \\
\text { (Trofast and } \\
\text { Wickberg 1976). }\end{array}$ & $\begin{array}{c}206(4.04), 269 \\
(3.85)\end{array}$ \\
\hline
\end{tabular}

\subsection{Secondary metabolites from the Diaporthe celastrina strain}

D. celastrina (AW 545) yielded a culture filtrate extract $(763 \mathrm{mg}$ ) with antifungal properties. Column chromatography similar to that described for the L. papyraceum strain above was used for this extract, yielding 10 fractions with a recovered weight of $728 \mathrm{mg}(95 \%)$. Four fractions displayed antifungal activity in the Oxford disk assay. Fraction 1 had a weight of $159.8 \mathrm{mg}$. This fraction was dissolved in $2.5 \mathrm{~mL}$ of $\mathrm{MeOH}$ and separated by RP-HPLC (same method as described above). Seven peaks were present in the chromatogram. The fifth peak was isolated as 
compound 5. Fraction $3(64.9 \mathrm{mg})$ was dissolved in $1.5 \mathrm{~mL} \mathrm{MeOH}$ and separated by HPLC. Six peaks were present in the HPLC chromatogram. Peak $5(18.1 \mathrm{mg})$ was purified resulting in the isolation of compound $\mathbf{6}$.

\section{Compound 5}

Compound 5 was a yellow oil with a weight of $86 \mathrm{mg}$. A UV (MeOH) maximum was observed at 218. The ESI-MS spectrum displayed a peak at $m / z 295.08[\mathrm{M}+\mathrm{H}]^{+}$. Primary fragmentation patterns showed other major peaks at 277.03, representing the $\left[\mathrm{M}-\mathrm{H}_{2} \mathrm{O}+\mathrm{H}\right]^{+},\left[(\mathrm{M}+\mathrm{H})-\mathrm{H}_{2} \mathrm{O}-\right.$ $\mathrm{ACN}]^{+}$peak at 235.97 , as well as the dimer $[2 \mathrm{M}+\mathrm{H}]^{+}$at 589.24 . The molecular formula was determined as $\mathrm{C}_{15} \mathrm{H}_{18} \mathrm{O}_{6}$, with a calculated mass of 294.1103. The unit of saturation was calculated as 7 .

There were six diagnostic protons in the ${ }^{1} \mathrm{H}$ NMR spectrum with shifts between $\delta 6.01$ and $\delta 7.14$ (Table 3.4). These deshielded protons are indicative of carbon - carbon double bonds. HMBC and COSY correlations indicated that four of these low-field protons at $\delta 6.26,(\mathrm{~d}, J=9.7), \delta$ 7.14, (dd, $J=9.7,5.8), \delta 5.68(\mathrm{dd}, J=5.9,2.9)$ and $\delta 6.01(\mathrm{ddd}, J=6.8,3.0,1.6)$ were located on a 6-membered ring. A $J$ coupling of $11.8 \mathrm{~Hz}$ confirmed a cis configuration of the vicinal protons at $\delta 6.39$ and $\delta 6.71$ bound to the ethylenic double bond at $\mathrm{C}^{\prime}$ ' and $\mathrm{C} 2^{\prime}$ (Figure 3.5). Additional COSY correlations were observed between the methyl protons at $\delta 1.32(\mathrm{~d}, J=7.0)$ (on C 5') and the methine proton at $\delta 4.30$ ( $(\mathrm{q}, J=7.0$ ) (on C 4'), as well as between the protons at $\delta 1.80(\mathrm{~m})$ (on C 4") and the methine proton at $\delta 6.87(\mathrm{q}, J=7.2)$ (on C 3").

The ${ }^{13} \mathrm{C}$ spectroscopic data showed carbonyl groups with chemical shifts at $\delta 204.3,164.1$ and 167.7. The most deshielded of these carbons at $\delta 204.3$ represents a ketone functional group, 
while the remaining two carbons $\left(\delta_{C 2} 164.1\right.$ and $\delta_{C 1}$, 167.7) had shifts that indicative of a lactone and an ester respectively. The NMR spectroscopic data were in accordance with that of phomopsolide A, isolated from the fungus Phomopsis oblonga (Grove 1985).

\section{Compound 6}

Compound 6 was isolated as a yellow oil, having a weight of $5.8 \mathrm{mg}$. The UV (MeOH) maxima were 333 and $241 \mathrm{~nm}$. Major peaks in the ESI-MS were the $m / z 194.95$ peak, representing the [M $+\mathrm{H}]^{+}$fragment, as well as the $m / z 235.97[\mathrm{M}+\mathrm{H}+\mathrm{ACN}]^{+}$. The molecular formula was determined as $\mathrm{C}_{10} \mathrm{H}_{10} \mathrm{O}_{4}$, with an exact mass of 194.0579 and an experimental mass observed via HRMS as $[\mathrm{M}-\mathrm{H}]^{-}$with the $\mathrm{m} / \mathrm{z} 193.0499$ and the associated mass error of $-3.52 \mathrm{ppm}$. The unsaturation index was calculated for this compound as 6 .

Similar chemical shifts were observed in the ${ }^{13} \mathrm{C}$ and ${ }^{1} \mathrm{H}$ NMR spectra for both compounds 5 and 6. The ${ }^{1} \mathrm{H}$ NMR spectrum contained 5 low-field protons between $\delta 6.43$ and $\delta 7.55$. This is one less than was observed for compound 5 on C6 (Table 3.4). Also, the proton attached to C 5 increased in shift from $\delta 5.68$ to a shift of $\delta$ 6.68. Moreover, COSY correlations were only observed between the protons on $\mathrm{C} 1^{\prime}$ and $\mathrm{C} 2^{\prime}$ '. This suggests the inclusion of a double bond and consequently the loss of a proton on $\mathrm{C}$. The increase in the $J$ value from $11.8 \mathrm{~Hz}$ (in compound 5) to $15.5 \mathrm{~Hz}$ in compound $\mathbf{6}$ would indicate a trans configuration of the protons at $\delta$ 7.25. The remaining COSY correlation between the methine (C 4') proton at $\delta 4.43(\mathrm{q}, \mathrm{J}=7.0)$ and the methyl $\left(\mathrm{C} 5^{\prime}\right)$ protons at $\delta 1.35(\mathrm{~d}, \mathrm{~J}=7.0)$ was similar to what was observed for compound 5 . 
The ${ }^{13} \mathrm{C}$ NMR spectra data showed only two carboxyl groups with shifts of $\delta 202.6$ and $\delta$ 167.2, the former is a keto group, while the latter, an ester function. Compound 6 contained a similar moiety (MeCHOHCO, $\mathrm{C} 3^{\prime}$ to $\mathrm{C} 5^{\prime}$ ) to that of compound 5 (Figure 3.5). The increase in the shifts of C 5 and C 6 from 64.7 and 78.4 (compound 5) to 112.0 and 158.2 (compound 6) respectively indicates the presence of an additional $\mathrm{C}=\mathrm{C}$ bond in compound $\mathbf{6}$.

This compound is known to be a stable pyrone also reported form P. oblanga (Grove 1985).

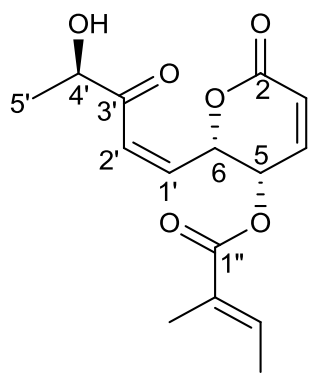

5

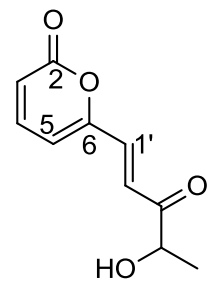

6

Figure 3.5 Phomopsolide A (5) and a pentaketide alpha pyrone (6). 
Table 3.4 Comparative ${ }^{1} \mathrm{H}$ and ${ }^{13} \mathrm{C}$ NMR data of compounds 5 and 6 (400.13 MHz, CD $\left.{ }_{3} \mathrm{OD}\right)$.

\begin{tabular}{|c|c|c|c|c|}
\hline \multirow{2}{*}{ Position } & \multicolumn{2}{|c|}{ Compound 5} & \multicolumn{2}{|c|}{ Compound 6} \\
\hline & $\delta_{\mathrm{C}}$, type & $\delta_{\mathrm{H}}(J$ in $\mathrm{Hz})$ & $\delta_{\mathrm{C}}$, type & $\delta_{\mathrm{H}}(J$ in $\mathrm{Hz})$ \\
\hline 2 & 164.1 & & 167.2 & \\
\hline 3 & $125.3, \mathrm{CH}$ & $6.26, \mathrm{~d}(9.7)$ & $118.5, \mathrm{CH}$ & 6.43, dd $(9.4,0.9)$ \\
\hline 4 & $142.4, \mathrm{CH}$ & $7.14, \mathrm{dd}(9.8,5.9)$ & $145.1, \mathrm{CH}$ & 7.55, dd $(9.4,6.6)$ \\
\hline 5 & $64.7, \mathrm{CH}$ & $5.68, \mathrm{dd}(5.9,2.9)$ & $112.0, \mathrm{CH}$ & 6.68, dd $(6.6,0.9)$ \\
\hline 6 & $78.4, \mathrm{CH}$ & 6.01. ddd $(6.8,3.0,1.6)$ & 158.2 & \\
\hline 1 ' & $142.4, \mathrm{CH}$ & $6.39, \mathrm{dd}(11.8,6.9)$ & 133.7, $\mathrm{CH}$ & $7.25, \mathrm{~d}(15.5)$ \\
\hline 2 ' & $126.1, \mathrm{CH}$ & $6.71, \mathrm{dd}(11.8,1.7)$ & $126.4, \mathrm{CH}$ & $7.25, \mathrm{~d}(15.5)$ \\
\hline 3 & 204.3 & & 202.6 & \\
\hline $4^{\prime}$ & $74.2, \mathrm{CH}$ & $4.30, \mathrm{q}(7.0)$ & $73.7, \mathrm{CH}$ & $4.43, \mathrm{q}(7.0)$ \\
\hline 5 & $19.6, \mathrm{CH}_{3}$ & $1.32, \mathrm{~d}(7.0)$ & $19.8, \mathrm{CH}_{3}$ & $1.35, \mathrm{~d}(7.0)$ \\
\hline $1 "$ & 167.7 & & & \\
\hline $2 "$ & 128.7 & & & \\
\hline $3 ”$ & $140.4, \mathrm{CH}$ & $6.87, \mathrm{q}(7.2)$ & & \\
\hline $4 "$ & $14.5, \mathrm{CH}_{3}$ & $1.80, \mathrm{~m}$ & & \\
\hline 2"-Me & $12.1, \mathrm{CH}_{3}$ & $1.79, \mathrm{~s}$ & & \\
\hline
\end{tabular}


Table 3.5 Summary of the physico-chemical properties of the D. celastrina compounds.

\begin{tabular}{|c|c|c|}
\hline Properties & 5 & 6 \\
\hline Appearance & yellow oil & yellow oil \\
\hline Empirical formula & $\mathrm{C}_{15} \mathrm{H}_{18} \mathrm{O}_{6}$ & $\mathrm{C}_{10} \mathrm{H}_{10} \mathrm{O}_{4}$ \\
\hline $\begin{array}{l}\text { ESI-MS }(m / z) \\
\text { or }\end{array}$ & $295.08[\mathrm{M}+\mathrm{H}]^{+}$ & \\
\hline $\begin{array}{l}\operatorname{HRMS}(m / z) \\
\text { Experimental mass }\end{array}$ & & $193.0499[\mathrm{M}-\mathrm{H}]^{-}$ \\
\hline Calculated mass & 294.1103 & 194.0579 \\
\hline $\mathrm{OR}[\alpha]_{D}^{T}$ & $\begin{array}{c}{[\alpha]_{D}^{22.4}+306.5^{\circ}(c} \\
1.64, \mathrm{MeOH})\end{array}$ & $\begin{array}{c}{[\alpha]_{D}^{24.1}-2.1^{\circ}(c 0.189} \\
\mathrm{MeOH})\end{array}$ \\
\hline \multirow{2}{*}{$\begin{array}{l}\mathrm{UV}(\mathrm{MeOH}) \lambda_{\max } \\
\mathrm{nm}(\log \varepsilon)\end{array}$} & 218 (4.37); & 333 (3.75), 241 (3.64); \\
\hline & $\begin{array}{l}\text { literature: } 217 \text { (4.19) } \\
\quad \text { (Grove 1985). }\end{array}$ & $\begin{array}{c}\text { literature: } 342(4.23), \\
240 \text { (4.11) (Grove } \\
1985) .\end{array}$ \\
\hline
\end{tabular}

\subsection{Secondary metabolites from the Seimatosporium sp. strain}

The third strain analyzed (NB 330) was an unidentified species of Seimatosporium believed to be related to the genus Lopherdermium. Combining the culture filtrate from the screening and bulk fermentations to give a weight of $1.20 \mathrm{~g}$. Similar fractionation methods employed for $L$. papyraceum were used for this extract. A total of 14 fractions were obtained with a weight of 1.16 g, a $97 \%$ recovery. Fractions 4 to 8 and 14 showed bioactivity against the common yeast $S$. cerevisiae and fractions 5 to 8 and 14 showed activity against M. violaceum. Fractions 6 and 7 were combined, totaling in a weight of $48 \mathrm{mg}$, due to the similarities in their LC-MS spectra. Eight peaks were observed in the HPLC chromatogram, peak 8 being compound 7. Fraction 8 (149 mg) was further analyzed by HPLC and showed 7 peaks in the chromatogram. Peaks 7 and 8 were compound 7 , while peak 6 was compound $\mathbf{8}$. Despite only demonstrating weak activity in 
the M. violaceum bioassay, fraction $12(39 \mathrm{mg})$ was analyzed and showed one major compound in its LC-MS spectrum. Four peaks were present in the HPLC chromatogram, the third was identified as compound 9 .

\section{Compound 7}

Compound 7 was isolated as a light brown oil with a weight of $14.9 \mathrm{mg}$. A UV (MeOH) maximum was observed at $217 \mathrm{~nm}$. Diagnostic peaks observed in the ESI-MS spectrum were assignable as the $m / z 295.02[\mathrm{M}+\mathrm{H}]^{+}$, the $m / z 336.10[(\mathrm{M}+\mathrm{ACN})+\mathrm{H}]^{+}$, and the dimer at $m / z$ $589.20[2 \mathrm{M}+\mathrm{H}]^{+}$.

The molecular formula was deduced as $\mathrm{C}_{15} \mathrm{H}_{18} \mathrm{O}_{6}$, with an exact mass of 294.1103 and an experimental mass of 295.1179 , representing the $[\mathrm{M}+\mathrm{H}]^{+}$peak, with an r.t. of $3.43 \mathrm{~min}$. and a mass error of $0.89 \mathrm{ppm}$. The unit of unsaturation calculated for this compound was 7.

The ${ }^{1} \mathrm{H}$ NMR spectrum showed 7 peaks, corroborating with the presence of five methyls and two methines being present in the molecule. In particular, the shifts of the protons at $\delta 2.11$ and $\delta$ 2.58 are indicative of aromatic methyl functionalities $\left(\delta\right.$ 2.3-2.7) (Pavia et al. 2001). The ${ }^{13} \mathrm{C}$ NMR spectrum showed 15 carbons, including five methyl groups, two methines and the remaining carbons were quaternary. One of the quaternary carbons was found to be a carboxylic acid $(\delta$ 175.2) while another was of an ester functionality $(\delta$ 161.9). The presence of a single hydroxyl group was elucidated with a diazomethane derivatization (compound 7.1, Figure 3.8). This would confirm the presence of a carboxylic acid.

Additionally, the singlet methyl at $\delta 3.88$ indicates a methyl ether functionality. HMBC correlations (Table 3.6) from the protons $\delta 2.11\left(\delta_{C} 11.3\right), \delta 2.58\left(\delta_{C} 17.4\right)$ and $\delta 6.51\left(\delta_{C} 98.1\right)$ 
suggested the carbons with the shifts $\delta 98.1, \delta 165.0, \delta 143.2, \delta 122.7, \delta 106.2$ and $\delta 157.6$ formed an aromatic ring. The two methyl groups at $\delta 11.3$ and $\delta 17.4$ were singlet groups located on the benzene ring. Since no coupling was observed between the single aromatic hydrogen at $\delta$ 6.51 and the protons at $\delta 2.11$ and $\delta 2.58$, it is suggested that these methyl groups are located at the para and meta positions relative to the aromatic proton. Additionally, HMBC correlations from the proton at $\delta 6.51$ would suggest that the carbon at $\delta 11.3$ is located at the meta position on the ring. The shift of a third methyl group at $\delta 56.5$ confirms the presence of a methoxy group; this is the third substituent of the aromatic ring, as the hydrogens bonding to this carbon ( $\delta 3.88$ ) show HMBC association to the carbon at $\delta$ 165.0.

This trisubstituted benzene ring is postulated to be attached to a benzodioxin ring containing the carbons at $\delta 157.6$ and a carbon at $\delta 106.0$, as well as the ester functional group at $\delta 161.9$ and a quaternary carbon bonded to a fourth methyl substituent $(\delta 20.9)$ at $\delta$ 107.2. This methyl group was also a singlet, with hydrogens confirming this second ring through HMBC data.

Another fragment of this molecule was deduced based on HMBC and COSY data. The only COSY coupling in the molecule existed between the protons on the methyl group at $\delta 12.8(\delta$ $1.28, \mathrm{~d} 7.0)$ and a methine with a shift at $\delta 47.8(\delta 3.18, \mathrm{q} 7.0)$. The carboxylic function at $\delta$ 175.2 was found to be adjacent to this $\mathrm{CH}$ group, giving rise to a propionic acid moiety. This fragment is found to be attached to the benzodioxin ring through the carbon at $\delta$ 107.2. Compound 7 (Figure 3.6) was proposed, having two adjacent stereocenters at the following carbons $\delta 47.8$ and $\delta$ 107.2. 


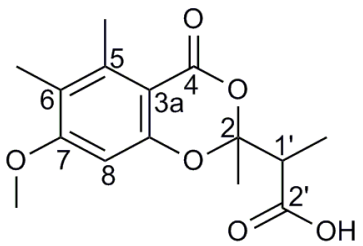

Figure 3.6 Compound 7, 2-(7-methoxy-2,5, 6-trimethyl-4-oxo-4 H-benzo[d][1,3]dioxin-2yl)propanoic acid.

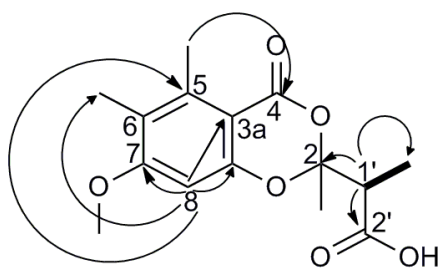

Figure 3.7 Key HMBC and COSY correlations observed for compound 7. 
Table 3.6 ${ }^{1} \mathrm{H}$ and ${ }^{13} \mathrm{C}$ NMR data for compound 7 (400.13 MHz, $\left.\mathrm{CD}_{3} \mathrm{OD}\right)$.

\begin{tabular}{|c|c|c|c|c|}
\hline Position & $\delta_{C}$, type & $\delta_{\mathrm{H}}(J$ in $\mathrm{Hz})$ & HMBC correlations & COSY correlations \\
\hline 2 & 107.2 & & & \\
\hline 4 & 161.9 & & & \\
\hline 5 & 122.7 & & & \\
\hline 6 & 143.2 & & & \\
\hline 7 & 165.0 & & & \\
\hline 8 & 98.1 & $6.51, \mathrm{~s}$ & $\begin{array}{l}11.3,106.2,122.7 \\
157.6,161.9,165.0\end{array}$ & \\
\hline $3 a$ & 157.6 & & & \\
\hline $3 b$ & 106.2 & & & \\
\hline 1 ' & $47.8, \mathrm{CH}$ & $3.18, \mathrm{q}(7.1)$ & $\begin{array}{c}12.8,20.9,107.2 \\
175.2\end{array}$ & 1.28 \\
\hline 2 ' & 175.2 & & & \\
\hline 2-Me & $20.9, \mathrm{CH}_{3}$ & $1.73, \mathrm{~s}$ & $\begin{array}{c}47.8,107.2 \\
98.1,106.2,122.7\end{array}$ & \\
\hline $5-\mathrm{Me}$ & $17.4, \mathrm{CH}_{3}$ & $2.58, \mathrm{~s}$ & $\begin{array}{c}143.2,157.6,161.9 \\
165.0\end{array}$ & \\
\hline 6-Me & $11.3, \mathrm{CH}_{3}$ & $2.11, \mathrm{~s}$ & $\begin{array}{l}98.1,106.2,122.7 \\
143.2,157.6,165.0\end{array}$ & \\
\hline 7-OMe & $56.5, \mathrm{CH}_{3}$ & $3.88, \mathrm{~s}$ & $98.1,165.0$ & \\
\hline 1'-Me & $12.8, \mathrm{CH}_{3}$ & $1.28, \mathrm{~d}(7.0)$ & $47.8,107.2,175.1$ & 3.18 \\
\hline
\end{tabular}

Figure 3.8 Compound 7.1, Compound 7.1, mono-methylated derivative of compound 7. 
Table 3.7 ${ }^{1} \mathrm{H}$ and ${ }^{13} \mathrm{C}$ NMR data for compound 7.1 (400.13 MHz, $\left.\mathrm{CD}_{3} \mathrm{OD}\right)$.

\begin{tabular}{|c|c|c|c|c|}
\hline Position & $\delta_{\mathrm{c}}$, type & $\delta_{\mathrm{H}}(J$ in $\mathrm{Hz})$ & HMBC correlations & COSY correlations \\
\hline 2 & 107.0 & & & \\
\hline 4 & 161.7 & & & \\
\hline 5 & 122.9 & & & \\
\hline 6 & 143.3 & & & \\
\hline 7 & 165.1 & & & \\
\hline 8 & 98.1 & $6.51, \mathrm{~s}$ & $\begin{array}{c}11.3,106.0,122.9,157.5 \\
161.7,165.1\end{array}$ & \\
\hline $3 a$ & 157.5 & & & \\
\hline $3 b$ & 106.0 & & & \\
\hline 1 , & $47.2, \mathrm{CH}$ & $3.27, \mathrm{~m}$ & $12.6,20.9,107.0,173.6$ & 1.27 \\
\hline $2^{\prime}$ & 173.6 & & & \\
\hline 2-Me & $20.9, \mathrm{CH}_{3}$ & $1.70, \mathrm{~s}$ & $\begin{array}{c}12.6,47.2,107.0,157.5 \\
161.7\end{array}$ & \\
\hline $5-\mathrm{Me}$ & $17.4, \mathrm{CH}_{3}$ & $2.59, \mathrm{~s}$ & $\begin{array}{c}98.1,106.0,122.9,143.3 \\
157.5,161.7,165.1\end{array}$ & \\
\hline 6-Me & $11.3, \mathrm{CH}_{3}$ & $2.12, \mathrm{~s}$ & $\begin{array}{c}98.1,106.0,122.9,143.3 \\
157.5,165.1\end{array}$ & \\
\hline 7-OMe & $56.5, \mathrm{CH}_{3}$ & $3.88, \mathrm{~s}$ & $52.5,98.1,165.1$ & \\
\hline 1'-Me & 12.6, $\mathrm{CH}_{3}$ & $1.27, \mathrm{~d}(7.1)$ & $47.2,107.0,173.6$ & 3.27 \\
\hline 2'-OMe & $52.5, \mathrm{CH}_{3}$ & $3.71, \mathrm{~s}$ & $56.5,173.6$ & \\
\hline
\end{tabular}

\section{Compound 8}

Compound 8 was isolated as a yellow oil and a weight of $46 \mathrm{mg}$. The UV (MeOH) maximum was measured at $205 \mathrm{~nm}$. ESI-MS peaks of importance were similar to those in the spectrum of compound 7. The $m / z 295.12[\mathrm{M}+\mathrm{H}]^{+}$peak, the $m / z 336.17[(\mathrm{M}+\mathrm{ACN})+\mathrm{H}]^{+}$and the dimer peak at $m / z 589.22[2 \mathrm{M}+\mathrm{H}]{ }^{+}$. The molecular formula was $\mathrm{C}_{15} \mathrm{H}_{18} \mathrm{O}_{6}$, with an exact mass of 
294.1103 and an observed mass of 293.1033 for the $[\mathrm{M}-\mathrm{H}]^{-}$peak, with an r.t. of 3.14 min. and a mass error of $0.76 \mathrm{ppm}$. The unit of unsaturation was 7.

The ${ }^{1} \mathrm{H}$ NMR spectroscopic data showed six different proton resonances corresponding to 16 protons. A single COSY coupling was observed between the methyl protons at $\delta 2.20$ (q, $J=1.6$ ) and $\delta 1.90(\mathrm{q}, J=1.4)$.

The ${ }^{13} \mathrm{C}$ NMR spectrum showed 15 carbons, five of which are methyls, and one methine group. Two carboxylic groups with shifts of $\delta 171.8$ and $\delta 172.4$ were suggested. Confirmation of both carboxylic groups was achieved by diazomethane methylation, as two new methoxy groups were present in the ${ }^{1} \mathrm{H}$ and ${ }^{13} \mathrm{C}$ NMR spectrum of compound 8.1 (Figure 3.11). HMBC cross-peaks from the protons at $\delta 6.36$ (on $\mathrm{C} 5$ ), the protons at $\delta 3.79$ (on $\mathrm{C} 4-\mathrm{OMe}$ ), as well as the protons at $\delta 2.11$ and $\delta 2.26$ of the two adjacent methyl groups at $\delta_{C 3-M e} 11.5$ and $\delta_{C 2-M e} 17.1$ respectively, confirmed a trisubstituted benzene ring similar to that in compound 7. A key difference between both compounds 7 and 8 was the disappearance of $\delta_{C} 47.8$ which was present in compound 7. However, HMBC data of the hydrogens on the methyl with a shift of $\delta 12.6(\delta 1.90)$ in this compound was similar to that of the carbon at $\delta 12.8(\delta 1.28)$ in compound 7 , indicating an identical molecular environment. A double bond was confirmed by the appearance of two deshielded carbons with shifts of $\delta 113.0$ and $\delta 162.8$.

Long range $\left({ }^{5} J\right)$ coupling was observed between the protons $\delta 1.90$, q (1.4) and $\delta 2.20$, q (1.6). Cis ${ }^{5} \mathrm{~J}$ coupling in a $\mathrm{Me}-\mathrm{C}=\mathrm{C}-\mathrm{Me}$ system has been observed at $1.2 \mathrm{~Hz}$, while a trans configuration is generally $1.6 \mathrm{~Hz}$. It was therefore postulated that these protons are located trans in respect to each other (Pavia et al. 2009). Identical couplings were observed in the derivatized compound (Table 3.9) with the protons at $\delta 1.88, \mathrm{q}(1.4)$ and $\delta 2.17, \mathrm{q}$ (1.4). HMBC data of these protons suggest a similar conformation to that of the protons at $\delta 1.28$ (on $\mathrm{C} 1-\mathrm{Me} \delta 12.8$ ) 
and $\delta 1.73$ (on C 2-Me $\delta$ 20.9) in compound 7. All remaining hydrogens produced singlet peaks in the spectrum (data summarized in Table 3.8).

The presence of a second $\mathrm{COOH}$ group and the appearance of a $\mathrm{C}=\mathrm{C}$ bond would indicate that a second ring is no longer present. The proposed structure (Figure 3.9) supports the lack of chirality in the chemical in agreement with the negligible OR measurement observed.

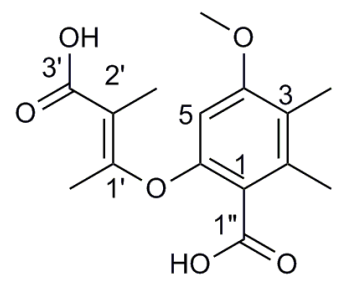

Figure 3.9 Compound 8, (E)-6-((3'-carboxybut-2'-en-2'-yl)oxy)-4-methoxy-2,3-dimethylbenzoic acid.

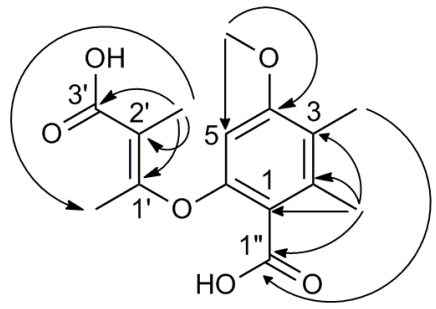

Figure 3.10 Characteristic HMBC correlations observed for compound 8 . 
Table 3.8 ${ }^{1} \mathrm{H}$ and ${ }^{13} \mathrm{C}$ NMR data for compound 8 (400.13 MHz, $\left.\mathrm{CD}_{3} \mathrm{OD}\right)$.

\begin{tabular}{|c|c|c|c|c|}
\hline Position & $\delta_{\mathrm{C}}$, type & $\delta_{\mathrm{H}}(J$ in $\mathrm{Hz})$ & HMBC correlations & COSY correlations \\
\hline 1 & 122.0 & & & \\
\hline 2 & 136.4 & & & \\
\hline 3 & 122.2 & & & \\
\hline 4 & 160.0 & & & \\
\hline 5 & $100.7, \mathrm{CH}$ & $6.36, \mathrm{~s}$ & $\begin{array}{c}11.5,122.0,122.2,150.9 \\
160.0,171.8\end{array}$ & \\
\hline 6 & 150.9 & & & \\
\hline 1 , & 162.8 & & & \\
\hline 2 & 113.0 & & & \\
\hline 3 & 172.4 & & & \\
\hline $1 ”$ & 171.8 & & & \\
\hline 2-Me & $17.1, \mathrm{CH}_{3}$ & $2.26, \mathrm{~s}$ & $\begin{array}{l}11.5,100.7,122.0,122.2 \\
136.4,150.9,160.0,171.8\end{array}$ & \\
\hline $3-\mathrm{Me}$ & $11.5, \mathrm{CH}_{3}$ & $2.11, \mathrm{~s}$ & $\begin{array}{c}100.7,122.0,122.2 \\
136.4,150.9,160.0,171.8\end{array}$ & \\
\hline 4-OMe & $56.2, \mathrm{CH}_{3}$ & $3.79, \mathrm{~s}$ & $100.7,160.0$ & \\
\hline $1 '-\mathrm{Me}$ & $17.5, \mathrm{CH}_{3}$ & 2.20, q (1.6) & $113.0,162.8,172.4$ & 1.90 \\
\hline 2'-Me & $12.6, \mathrm{CH}_{3}$ & $1.90, \mathrm{q}(1.4)$ & $17.5,113.0,162.8,172.4$ & 2.20 \\
\hline
\end{tabular}<smiles>COC(=O)/C(C)=C(\C)Oc1cc(OC)c(C)c(C)c1C(=O)OC</smiles>

Figure 3.11 Compound 8.1, the diazomethane derivatized form of compound 8 . 
Table 3.9 ${ }^{1} \mathrm{H}$ and ${ }^{13} \mathrm{C}$ NMR data for compound $8.1\left(400.13 \mathrm{MHz}, \mathrm{CD}_{3} \mathrm{OD}\right)$.

\begin{tabular}{|c|c|c|c|c|}
\hline Position & $\delta_{\mathrm{C}}$, type & $\delta_{\mathrm{H}}(J$ in $\mathrm{Hz})$ & HMBC correlations & COSY correlations \\
\hline 1 & 120.9 & & & \\
\hline 2 & 137.0 & & & \\
\hline 3 & 122.6 & & & \\
\hline 4 & 160.4 & & & \\
\hline 5 & $101.2, \mathrm{CH}$ & $6.39, \mathrm{~s}$ & $\begin{array}{c}11.5,120.9, \underset{122.6,151.4,160.4}{170.1} \\
\text {, }\end{array}$ & \\
\hline 6 & 151.4 & & & \\
\hline 1 ' & 163.1 & & & \\
\hline $2^{\prime}$ & 112.3 & & & \\
\hline $3^{\prime}$ & 170.8 & & & \\
\hline $1 "$ & 170.1 & & & \\
\hline 2-Me & $17.0, \mathrm{CH}_{3}$ & $2.20, \mathrm{~s}$ & 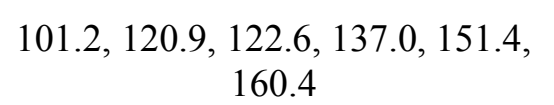 & \\
\hline 3-Me & $11.5, \mathrm{CH}_{3}$ & $2.12, \mathrm{~s}$ & $\begin{array}{c}101.2,120.9, \begin{array}{l}122.6,137.0,151.4 \\
160.4\end{array} \\
\text {, }\end{array}$ & \\
\hline $4-\mathrm{OMe}$ & $56.3, \mathrm{CH}_{3}$ & $3.80, \mathrm{~s}$ & 163.1 & \\
\hline $1^{\prime}-\mathrm{Me}$ & $17.4, \mathrm{CH}_{3}$ & 2.17, q (1.4) & $112.3,163.0,170.8$ & 1.89 \\
\hline 2'-Me & $12.3, \mathrm{CH}_{3}$ & $1.89, \mathrm{q}(1.4)$ & $163.1,170.8$ & 2.17 \\
\hline 3'-OMe & $51.9, \mathrm{CH}_{3}$ & $3.74, \mathrm{~s}$ & 170.8 & \\
\hline $1 "-\mathrm{OMe}$ & $52.6, \mathrm{CH}_{3}$ & $3.81, \mathrm{~s}$ & 170.1 & \\
\hline
\end{tabular}

\section{Compound 9}

Compound 9 was isolated as a light brown oil with a weight of $6.9 \mathrm{mg}$. The UV (MeOH) maximum was determined at $228 \mathrm{~nm}$. There were however major differences in the ESI-MS spectrum. Characteristic peaks observed were the $m / z 311.08[\mathrm{M}+\mathrm{H}]^{+}$, the $m / z 293.05[(\mathrm{M}+$ $\left.\left.\mathrm{H}_{2} \mathrm{O}\right)+\mathrm{H}\right]^{+}$, the $m / z 352.12[(\mathrm{M}+\mathrm{ACN})+\mathrm{H}]^{+}$and the dimer at $m / z 621.13[2 \mathrm{M}+\mathrm{H}]^{+}$. The molecular formula was $\mathrm{C}_{15} \mathrm{H}_{18} \mathrm{O}_{7}$, with an exact mass of 310.1052 and an experimental mass of 333.0943, representing the $[\mathrm{M}+\mathrm{Na}]^{+}$peak of r.t. $2.79 \mathrm{~min}$. and a mass error of -0.60 . The UV 
profile of this compound was similar to that of compound 7. The unit of unsaturation calculated for this compound was 7 .

The ${ }^{1} \mathrm{H}$ NMR spectrum was very similar to that of compound 7 , with the exception of the shift at $\delta 4.69$ of a newly added methylene. HMBC correlations of these two protons were in a similar environment to those on 6-Me $(\delta 2.11)$ in compound 7. Indicating that methyl group has been hydroxylated in compound $\mathbf{9}$.

All carbon shifts in the ${ }^{13} \mathrm{C}$ NMR spectrum of compound 7 were present in compound 9 except the carbon located at $\delta_{C}$ 11.3. Additionally, a methylene was present in compound 9 with a shift of $\delta 55.1$, with equivalent protons at $\delta 4.70$, s. A methylene of this shift would suggest a hydroxymethyl function. The remaining 14 carbons were composed of two methines, three methyl groups and eight quaternary carbons. Spectroscopic data would suggest that compound 9 is similar to compound 7, except for the substituting of a methyl group for a primary alcohol group. This compound also possesses two adjacent stereocenters. Drawing from the similarities between compounds 7 and 9 , as well as the 1D and 2D NMR experiments, the structure in Figure 3.12 was suggested (spectroscopic data in Table 3.10).

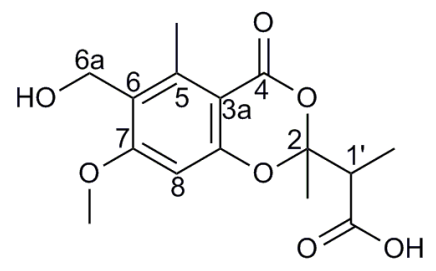

Figure 3.12 Compound 9, 2-(6-(hydroxymethyl)-7-methoxy-2,5-dimethyl-4-oxo-4Hbenzo[d][1,3]dioxin-2-yl)propanoic acid. 


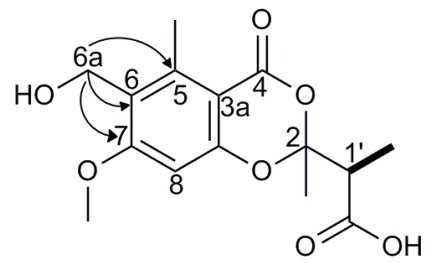

Figure 3.13 Diagnostic HMBC and COSY correlations observed for compound 9.

Table 3.10 ${ }^{1} \mathrm{H}$ and ${ }^{13} \mathrm{C}$ NMR data for compound 9 (400.13 MHz, $\left.\mathrm{CD}_{3} \mathrm{OD}\right)$.

\begin{tabular}{|c|c|c|c|c|}
\hline Position & $\delta_{\mathrm{C}}$, type & $\delta_{\mathrm{H}}(J$ in $\mathrm{Hz})$ & HMBC correlations & COSY correlations \\
\hline 2 & 107.3 & & & \\
\hline 4 & 161.5 & & & \\
\hline 5 & 125.4 & & & \\
\hline 6 & 145.7 & & & \\
\hline 7 & 165.6 & & & \\
\hline 8 & 98.6, CH & $6.57, \mathrm{~s}$ & $\begin{array}{c}55.1,106.4,125.4,159.3, \\
161.5,165.6\end{array}$ & \\
\hline $3 a$ & 159.3 & & & \\
\hline $3 b$ & 106.4 & & & \\
\hline $6 a$ & $55.1, \mathrm{CH}_{2}$ & $4.69, \mathrm{~s}$ & $125.4,145.7,165.6$ & \\
\hline 1 ' & 47.7, $\mathrm{CH}$ & $3.19, \mathrm{q}(7.0)$ & $12.8,21.0,107.3,175.0$ & 1.29 \\
\hline 2 & 157.0 & & & \\
\hline 2-Me & $21.0, \mathrm{CH}_{3}$ & $1.74, \mathrm{~s}$ & $47.7,107.3$ & \\
\hline $5 \mathrm{Me}$ & $17.0, \mathrm{CH}_{3}$ & $2.71, \mathrm{~s}$ & $\begin{array}{c}98.6,106.4,125.4,145.7 \\
159.3,161.5,165.6\end{array}$ & \\
\hline 7-OMe & $56.7, \mathrm{CH}_{3}$ & $3.90, \mathrm{~s}$ & $98.6,165.7$ & \\
\hline $1^{\prime}-\mathrm{Me}$ & $12.8, \mathrm{CH}_{3}$ & $1.29, \mathrm{~m}$ & $47.7,107.3,175.0$ & 3.19 \\
\hline
\end{tabular}


Table 3.11 Summary of the physico-chemical properties of isolated Seimatosporium sp. compounds.

\begin{tabular}{l|ccc}
\hline Properties & $\mathbf{7}$ & $\mathbf{8}$ & $\mathbf{9}$ \\
\hline Appearance & Light brown oil & Yellow oil & Light brown oil \\
Empirical formula & $\mathrm{C}_{15} \mathrm{H}_{18} \mathrm{O}_{6}$ & $\mathrm{C}_{15} \mathrm{H}_{18} \mathrm{O}_{6}$ & $\mathrm{C}_{15} \mathrm{H}_{18} \mathrm{O}_{7}$ \\
$\begin{array}{l}\text { ESI-MS }(m / z) \\
\text { or }\end{array}$ & & & \\
$\begin{array}{l}\text { HRMS }(m / z) \\
\text { Experimental mass }\end{array}$ & $295.1179[\mathrm{M}+\mathrm{H}]^{+}$ & $293.1033[\mathrm{M}-\mathrm{H}]^{-}$ & $333.0943[\mathrm{M}+\mathrm{Na}]^{+}$ \\
Calculated mass & 294.1103 & 294.1103 & 310.1052 \\
OR $[\alpha]_{D}^{T}$ & at $[\alpha]_{D}^{23.1} \mathrm{was}+8.0^{\circ}$ & & at $[\alpha]_{D}^{23.6} \mathrm{was}+10.7^{\circ}$ \\
& $(c 0.275, \mathrm{MeOH})$ & & $(c 0.335, \mathrm{MeOH})$ \\
$\mathrm{UV}(\mathrm{MeOH}) \lambda_{\max }$ & $217(4.23)$ & $205(4.34)$ & $228(4.12)$ \\
$\mathrm{nm}(\log \varepsilon)$ & & &
\end{tabular}

\subsection{Antimicrobial assay results}

Compounds 1 - 9 (Figure 3.14) were tested for antibacterial and antifungal activity against $B$. subtilis, E. coli, M. violaceum and S. cerevisiae. Data obtained for each compound as well as the positive and negative controls were analyzed at 6 hours for both bacteria and at 24 hours for both fungi; $p$ values below 0.05 were considered to be significantly different. See Appendix C for biological assay graphs. 
<smiles></smiles>

1<smiles>C/C=C(\Cl)C1=C(Cl)C(=O)C2=C(CC(O)C(C)(C)O2)C1=O</smiles>

4<smiles>COc1cc2c(c(C)c1C)C(=O)OC(C)(C(C)C(=O)O)O2</smiles>

7<smiles>C/C=C(\Cl)C1=CC(=O)[C@@]23C[C@H](C)[C@@](C)(O[C@]2(O)C1=O)O3</smiles>

2<smiles>C/C=C(\C)C(=O)O[C@H]1C=CC(=O)O[C@H]1/C=C\C(=O)[C@@H](C)O</smiles>

5<smiles>C/C=C(\Cl)C1=C(Cl)C(=O)[C@@]23C[C@H](C)O[C@]2(O)C(=O)C13</smiles>

3<smiles>CC(O)C(=O)/C=C/c1cccc(=O)o1</smiles>

6

Figure 3.14 Compounds 1 - 9.

\subsubsection{B. subtilis}

All 9 compounds displayed varying degrees of activity against the gram positive bacterium $B$. subtilis. Compound 1 showed significant activity at $500 \mu \mathrm{M}(p=0.004)$. Compound 2 displayed antibacterial activity at $500 \mu \mathrm{M}(p=0.0), 50 \mu \mathrm{M}(p=0.0)$, as well as $5 \mu \mathrm{M}(p=0.003)$; 
moreover at $500 \mu \mathrm{M}$, compound $\mathbf{2}$ was not statistically different from the positive control chloramphenicol at $500 \mu \mathrm{M}(p=0.344)$. Compound $\mathbf{3}$, similarly to compound 2 inhibited bacterial growth at all three tested concentrations; at $500 \mu \mathrm{M}(p=0.0)$, at $50 \mu \mathrm{M}(p=0.0)$ and 5 $\mu \mathrm{M}(p=0.0)$. At 50 and $500 \mu \mathrm{M}$, this compound was more potent $(p=0.0)$ than the positive control which was at a concentration of $500 \mu \mathrm{M}$. Again, compound 4 showed activity against this bacterium at $500 \mu \mathrm{M}(p=0.0), 50 \mu \mathrm{M}(p=0.0)$ and $5 \mu \mathrm{M}(p=0.0)$. At a concentration of 500 $\mu \mathrm{M}$ and $50 \mu \mathrm{M}$, compound 4 was not different than the positive control at $500 \mu \mathrm{M}$ with $p$ values of 0.995 and 0.983 respectively. Compound 5 showed inhibitory activity at $500 \mu \mathrm{M}(p=0.0)$ and $50 \mu \mathrm{M}(p=0.0)$, and was not statistically different from chloramphenicol at $500 \mu \mathrm{M}(p=0.261)$. Compound 6 displayed activity against this bacterium only at $500 \mu \mathrm{M}(p=0.0)$. At $500 \mu \mathrm{M}$ as well as $50 \mu \mathrm{M}$, compound 7 was significantly different than DMSO with $p$ values of 0.0 and 0.001 respectively. Compound 8 showed activity at concentrations of $500 \mu \mathrm{M}(p=0.0)$ and at 50 $\mu \mathrm{M}(p=0.003)$. Finally, compound 9 showed significant activity at all three concentrations, 500 $\mu \mathrm{M}(p=0.0), 50 \mu \mathrm{M}(p=0.037)$, and $5 \mu \mathrm{M}(p=0.04)$. 
Table 3.12 Antibacterial activity of compounds 1-9 towards B. subtilis.

\begin{tabular}{|c|c|c|c|}
\hline \multirow[b]{2}{*}{ Compounds } & \multicolumn{3}{|c|}{ Concentrations } \\
\hline & $500 \mu \mathrm{M}$ & $50 \mu \mathrm{M}$ & $5 \mu \mathrm{M}$ \\
\hline Compound 1 & $+(p=0.004)$ & - & - \\
\hline Compound 2 & $++\quad(p=0.0)$ & $+\quad(p=0.0)$ & $+\quad(p=0.003)$ \\
\hline Compound $\mathbf{3}$ & $+++\quad(p=0.0)$ & $+++\quad(p=0.0)$ & $+\quad(p=0.0)$ \\
\hline Compound 4 & $++\quad(p=0.0)$ & $++\quad(p=0.0)$ & $+(p=0.0)$ \\
\hline Compound 5 & $++\quad(p=0.0)$ & $+\quad(p=0.0)$ & - \\
\hline Compound 6 & $+(p=0.0)$ & - & - \\
\hline Compound 7 & $+(p=0.0)$ & $+\quad(p=0.001)$ & - \\
\hline Compound $\mathbf{8}$ & $+(p=0.0)$ & $+\quad(p=0.003)$ & - \\
\hline Compound 9 & $+(p=0.0)$ & $+\quad(p=0.037)$ & $+(p=0.04)$ \\
\hline
\end{tabular}

+ , statistically significant bioactivity was observed.

++ , at these concentrations, the activity observed was comparable to that of the positive control chloramphenicol $(500 \mu \mathrm{M})$.

+++ , at these concentrations, the activity surpassed that of chloramphenicol $(500 \mu \mathrm{M})$.

\subsubsection{E. coli}

No significant activity was observed for compounds $\mathbf{1}$ and $\mathbf{9}$. Compounds $\mathbf{2}$ and $\mathbf{3}$ showed significant activity at the 3 concentrations with identical $p$ values, $500 \mu \mathrm{M}(p=0.0), 50 \mu \mathrm{M}(p=$ $0.0)$, and $5 \mu \mathrm{M}(p=0.001)$. Compound 4, displayed similar activities to compounds 2 and 3: 500 $\mu \mathrm{M}(p=0.0), 50 \mu \mathrm{M}(p=0.0)$, and $5 \mu \mathrm{M}(p=0.002)$.Compounds $5-\mathbf{8}$ only showed inhibitory activity at $500 \mu \mathrm{M}(p=0.0$, except compound $\mathbf{8}$, with $p=0.003)$. 
Table 3.13 Antibacterial activity of compounds 1-9 towards E. coli.

\begin{tabular}{|c|c|c|c|}
\hline \multirow{2}{*}{ Compounds } & \multicolumn{3}{|c|}{ Concentrations } \\
\hline & $500 \mu \mathrm{M}$ & $50 \mu \mathrm{M}$ & $5 \mu \mathrm{M}$ \\
\hline Compound $\mathbf{1}$ & - & - & - \\
\hline Compound 2 & $+\quad(p=0.0)$ & $+(p=0.0)$ & $+(p=0.001)$ \\
\hline Compound $\mathbf{3}$ & $+\quad(p=0.0)$ & $+(p=0.0)$ & $+(p=0.001)$ \\
\hline Compound 4 & $+\quad(p=0.0)$ & $+(p=0.0)$ & $+(p=0.002)$ \\
\hline Compound $\mathbf{5}$ & $+\quad(p=0.0)$ & - & - \\
\hline Compound 6 & $+\quad(p=0.0)$ & - & - \\
\hline Compound 7 & $+\quad(p=0.0)$ & - & - \\
\hline Compound 8 & $+(p=0.003)$ & - & - \\
\hline Compound 9 & - & - & - \\
\hline
\end{tabular}

+ , statistically significant bioactivity was observed.

\subsubsection{S. cerevisiae}

Compounds $7-9$ displayed no significant $(p>0.05)$ activity in these assays. Compound $\mathbf{1}$, at $500 \mu \mathrm{M}(p=0.005)$, displayed activity against the common yeast. Compounds $\mathbf{2}$ and $\mathbf{3}$ were both significantly different than DMSO at $500 \mu \mathrm{M}(p=0.0)$ and $50 \mu \mathrm{M}(p=0.0)$. Furthermore, at 500 $\mu \mathrm{M}$, both compounds were not different than nystatin $(5 \mu \mathrm{M})$, with $p$ values of 0.409 for compound $\mathbf{2}$ and 1.0 for compound $\mathbf{3}$. Compound $\mathbf{4}$ displayed statistically significant activity at $500 \mu \mathrm{M}(p=0.0)$ and was also comparable to nystatin $(5 \mu \mathrm{M})$, with $p=0.783$. Compound 5 showed activity at $500 \mu \mathrm{M}(p=0.0)$ and at $50 \mu \mathrm{M}(p=0.009)$, while compound 6 was more potent with activities at $500 \mu \mathrm{M}(p=0.0), 50 \mu \mathrm{M}(p=0.0)$ and $5 \mu \mathrm{M}(p=0.0)$. 
Table 3.14 Antifungal activity of compounds 1-9 towards $S$. cerevisiae.

\begin{tabular}{|c|c|c|c|}
\hline \multirow[b]{2}{*}{ Compounds } & \multicolumn{3}{|c|}{ Concentrations } \\
\hline & $500 \mu \mathrm{M}$ & $50 \mu \mathrm{M}$ & $5 \mu \mathrm{M}$ \\
\hline Compound 1 & $+(p=0.005)$ & - & - \\
\hline Compound 2 & $++\quad(p=0.0)$ & $(p=0.0)$ & - \\
\hline Compound $\mathbf{3}$ & $++\quad(p=0.0)$ & $+\quad(p=0.0)$ & - \\
\hline Compound 4 & $++\quad(p=0.0)$ & - & - \\
\hline Compound 5 & $+\quad(p=0.0)$ & $+\quad(p=0.009)$ & - \\
\hline Compound 6 & $+\quad(p=0.0)$ & $(p=0.0)$ & $(p=0.0)$ \\
\hline Compound 7 & - & - & - \\
\hline Compound 8 & - & - & - \\
\hline Compound 9 & - & - & - \\
\hline
\end{tabular}

+ , statistically significant bioactivity was observed.

++ , at these concentrations, the activity observed was comparable to that of the positive control nystatin $(5 \mu \mathrm{M})$.

\subsubsection{M. violaceum}

Compounds $\mathbf{1}$ and $\mathbf{5}$ did not display any significant activity against M. violaceum. Compounds $\mathbf{2}$ and 3 had similar activities at $500 \mu \mathrm{M}(p=0.0)$ and at $50 \mu \mathrm{M}(p=0.0)$, However, compound 2 (500 $\mu \mathrm{M}$ and $p=0.16$ ) was no different than nystatin at $5 \mu \mathrm{M}$. Compound 4 displayed inhibitory activity at 500,50 and $5 \mu \mathrm{M}$ ( $p=0.0$ for all concentrations). This compound was also comparable to nystatin $(5 \mu \mathrm{M})$ with a $p$ value of 1.0 . Compound 6 , only showed activity at 500 $\mu \mathrm{M}(p=0.0)$. For compound 7 , inhibitory activity was observed at 500,50 and $5 \mu \mathrm{M}(p=0.0$ for all concentrations). Compound $\mathbf{8}$ only showed significantly different results at both 50 ( $p=0.01)$ and $5(p=0.0) \mu \mathrm{M}$. This could be attributed to poor dispersal of cells. Compound 9 showed activity at all tested concentrations: $500 \mu \mathrm{M}(p=0.009), 50 \mu \mathrm{M}(p=0.0)$ and $5 \mu \mathrm{M}(p=0.0)$. 
Table 3.15 Antifungal activity of compounds 1-9 towards M. violaceum.

\begin{tabular}{l|ccc}
\hline \multicolumn{1}{l}{ Compounds } & $500 \mu \mathrm{M}$ & Concentrations \\
\hline Compound $\mathbf{1}$ & - & $50 \mu \mathrm{M}$ & $5 \mu \mathrm{M}$ \\
\hline Compound $\mathbf{2}$ & $++(p=0.0)$ & $+(p=0.0)$ & - \\
Compound $\mathbf{3}$ & $+(p=0.0)$ & $+(p=0.0)$ & - \\
Compound $\mathbf{4}$ & $++(p=0.0)$ & $+(p=0.0)$ & $+(p=0.0)$ \\
Compound $\mathbf{5}$ & - & - & - \\
Compound $\mathbf{6}$ & $+(p=0.0)$ & $+(p=0.0)$ & $+(p=0.0)$ \\
Compound $\mathbf{7}$ & $+(p=0.0)$ & $+(p=0.0)$ & $+(p=0.0)$ \\
Compound $\mathbf{8}$ & - & $+(p=0.0)$ & + \\
Compound $\mathbf{9}$ & $+(p=0.009)$ & & + \\
\hline
\end{tabular}

+ , statistically significant bioactivity was observed.

++ , at these concentrations, the activity observed was comparable to that of the positive control nystatin $(5 \mu \mathrm{M})$. 


\section{Discussion}

Endophyte communities within a given conifer stand are characterized by having a highly phylogenetically diversity. Needles of all conifers studied to date are inhabited by endophytes, and all seedlings are invariably colonized by endophytes from adjacent mature trees if present. Horizontal infection is influenced by climatic conditions. The frequency of infection in Douglas fir was shown to be influenced by precipitation, which affected the distribution of spores (Carroll 1988). By inoculating seedlings we hope to colonize conifers with beneficial endophytes. This will therefore increase the chance of having conifer endophytic communities dominated by thoroughly selected endophytes. Beneficial endophytes are defined here as those endophytes that confer benefits to plant hosts, such as increase in fitness and defense against disease.

The mutualistic relationship observed between grasses and their endophytes has long been proposed in conifers. Several studies have illustrated that conifer foliar endophytes can adequately provide their host trees with a more robust defense mechanism in light of insect predation. For example, the presence of $R$. parkeri in galls reduced the survival rate of gall midges of the genus Contarinia. More recently, it has been surmised that this mutualism, due to the presence of endophytes, could confer greater tolerance in conifer hosts towards the basidiomycete C. ribicola, the causative agent of white pine blister rust.

Although no pine species has been established as being tolerant to the C. ribicola pathogen, some trees have demonstrated a greater tolerance towards this fungus. Some preliminary studies, in particular that of Ganley et al. (2008) have shown that the presence of certain endophytes were able to increase conifer fitness and reduce the severity of $C$. ribicola. It is assumed that the fungal endophytes in these seemingly healthier trees may be different than those produced in the 
more susceptible trees. Studies have demonstrated that some secondary metabolites isolated from the endophytes infecting these trees confer tolerance towards C. ribicola.

Due to the difficulty in maintaining viable $C$. ribicola cultures outside the plant, $C$. ribicola has rarely been successfully cultured in laboratory setting. Tedious methods are required for fungal growth and these methods do not always guarantee the successful growth of the fungus on artificial media (Harvey \& Grasham 1970). In a recent study, a method was developed for the successful and reproducible culture of $C$. ribicola in vitro. Pyrenophorol was toxic to haploid cultures of C. ribicola (Sumarah et al. 2015).

To conduct an effective study of the endophytic community in a region, it is important to understand the genotypic diversity of the endophytes present. In order to achieve this, adequate sampling methods are required as well as sufficient strains from a large number of trees to provide a representative subset of the endophytic population. For this thesis, endophyte strains were obtained from several different regions within the Acadian forest (see Appendix D for endophyte collection sites). A total of 89 endophyte strains were screened for antifungal activity towards S. cerevisiae and M. violaceum. From these, $45.0 \%$ were found to be biologically active. Three of these strains, L. papyraceum, D. celestrina and Seimatosporium sp., were then grown in bulk for further secondary metabolite production analysis. The lineages of each fungus is outlined in Figure 4.1. 


\section{Eukaryota}

Fungi

Dikarya

Phylum

Ascomycota

Sub-phylum

Pezizomycotina

Class

Leotiomycetes

Sordariomycetes

Sordariomycetes

Sub-class

Sordariomycetidae

Xylariomycetidae

Order

Helotiales

Diaporthales

Xylariales

Family

Hyaloscyphaceae

Diapothaceae

Amphisphaeriaceae

Genus

Lachnum

Diaporthe

Seimatosporium

Figure 4.1 The lineages of L. papyraceum, D. celastrina and Seimatosporium sp.

The D. celastrina and L. papyraceum species were both isolated from red spruce (Picea ruben) needles. The Seimatosporium sp. however was isolated from the understory shrub Rhododendron groenlandicum (Bog Labrador tea). During the screening for nematode-trapping fungi, the woodinhabiting Ascomycete L. papyraceum was discovered (Anke et al. 1994). L. papyraceum is a prolific producer of secondary metabolites, most of which were found to be biologically active. Over 30 metabolites have been reported from L. papyraceum (Anke et al. 1994), most of which exhibited strong nematicidal activity against Caenorhabditis elegans and Meloidogyne incognita. Chlorinated compounds are naturally produced by L. papyraceum, however, by introducing calcium bromide in the culture medium during secondary metabolism, novel bromine containing metabolites were obtained (Stadler et al. 1994).

Four quinones (compounds 1-4) were isolated from L. papyraceum. Compound 1, known as dechloromycorrhizin A has been previously isolated from this species. The stereochemistry was 
found to be $\left(l^{\prime} Z\right)$-dechloromycorrhizin A based on the observed $J_{1^{\prime}{ }^{\prime}}$ as $11.9 \mathrm{~Hz}$ instead of 15.9 $\mathrm{Hz}$ determined for the diastereoisomer ( $\left.l^{\prime} E\right)$-dechloromycorrhizin A (Stadler \& Anke 1995). Mycorrhizin A (compound 2) is a known antibiotic compound. The third compound isolated from this fungus was chloromycorrhizin A. Compound $\mathbf{4}$ was reported here for the first time. Although it resembles the previous 3 mycorrhizins, in particular compound $\mathbf{3}$, there are some key structural changes that were elucidated by spectroscopic data (Table3.2). The OR reading was also different for this compound in comparison to compound $\mathbf{3}$ (Table 3.3).

The ascomycete genus Diaporthe (Phomopsis) comprise endophytes, pathogens and saprobes of a wide variety of plant hosts. The anamorph or asexual species are within the genus Phomopsis (Diogo et al. 2010; Gomes et al. 2013). Some Diaporthe species can alternate between being pathogenic and harmless endophytes depending on the host and the health of the host. Moreover, some endophytic species in this genus are known to produce secondary metabolites that can deter herbivory (Gomes et al. 2013). The compounds isolated from this fungus were the C15 dihydropyrone phomopsolide A (5) and the C10 pyrone compound (6). For compound 5, although not present in the HRMS, spectroscopic data and physical data justifies this compound as well as it was consistent with what was observed in the literature. These compounds were first isolated from P. oblanga.

Preliminary studies of endophytic communities of understory plants co-occurring with conifers have been conducted in the Acadian forest. Vaccinium angustifolium, lowbush blueberry was found to harbour an undescribed Xylaria sp., an endophyte that was also isolated from P. strobus needles in that same region (Richardson et al. 2014). Both endophyte isolates produced the potent antifungal compound griseofulvin in vitro. From decades of analysis of the different conifer endophytes in this region, endophytes having two such distinct hosts are not very 
common. Spruce seedlings inoculated with the endophyte Phialocephala scopiformis did not result in the horizontal transfer of this endophyte to neighbouring trees. These results are a clear indication of the vast ecological complexity of endophytes and plants (Richardson et al. 2014). Labrador tea shrubs (Figure 4.2) are generally found in wet coniferous forests and are often associated with black spruce (P. marina) (Northern Ontario Plant Database, 2015). Very little is known of the endophytic community in these plants. The three compounds isolated from Seimatosporium sp. (7-9) are reported here for the first time.

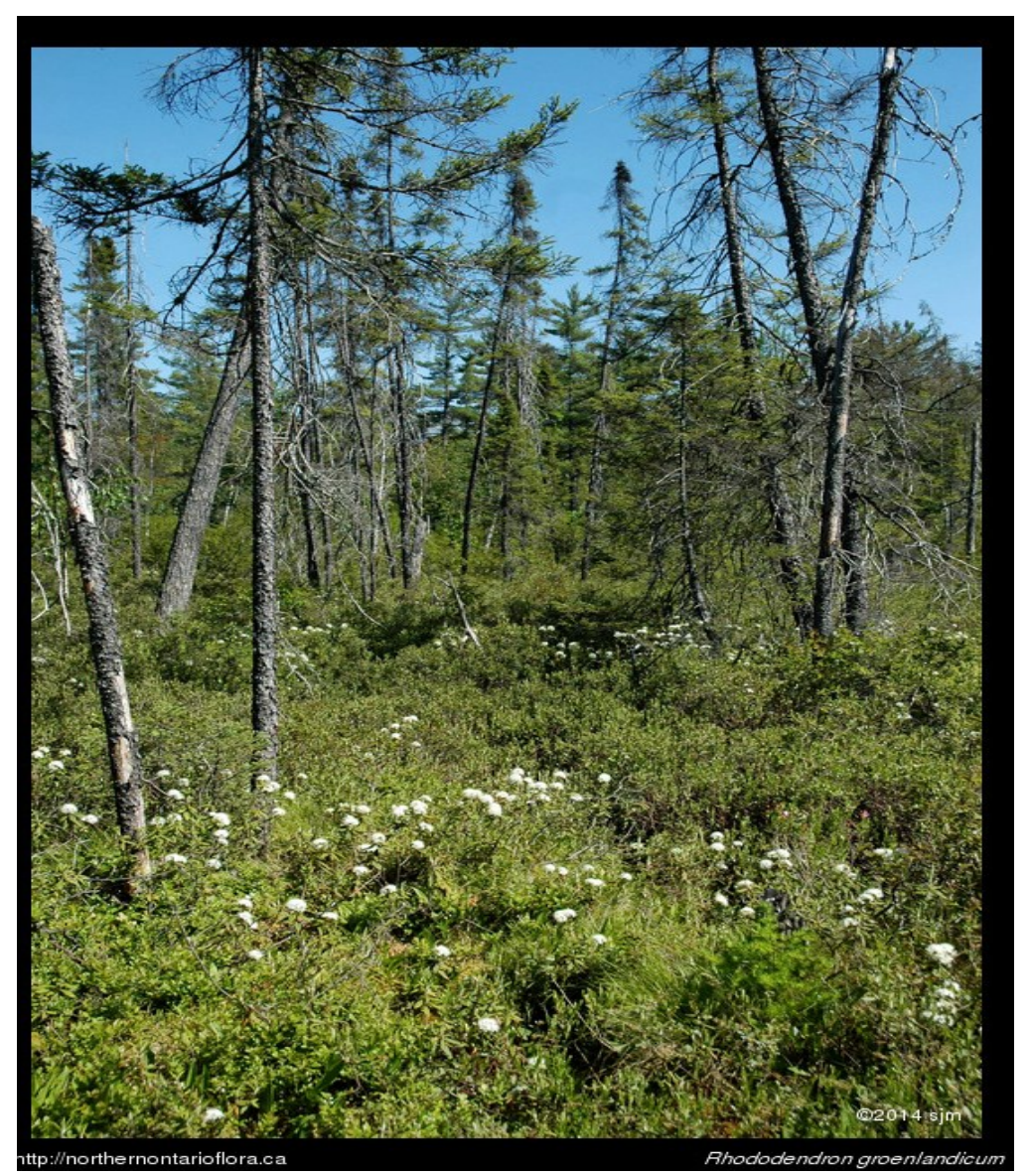

Figure 4.2 Flowering R. groenlandicum (Labrador tea) shrubs among conifers (Northern Ontario Plant database, 2015).

Based on the structure of these compounds, they are all produced via a polyketide or shikimic acid biosynthetic pathway. The L. papyraceum compounds isolated in this thesis are polyketides, 
possessing a quinone functionality. The three mycorrhizin derivatives (1-3) arise from a pentaketide origin. Dechloromycorrhizin A was initially a by-product obtained during the total synthesis of mycorrhizin A (Stadler et al. 1993a). This metabolite is known to be produced solely by L. papyraceum. Both diastereoisomers have been isolated in similar quantities (Stadler et al. 1995). Compound 4 also contains a quinone backbone in its structure and would appear to be related to the compound chloromycorrhizinol A (see Figure 4.3) (Trofast 1978). In contrast to compound 4, chloromycorrhizinol A was isolated as a white solid, displaying no biological activity in the assays used in that study.<smiles>C/C=C(/Cl)C1=C(Cl)C(=O)C2=C(C[C@H](O)C(C)(C)O2)C1=O</smiles>

a

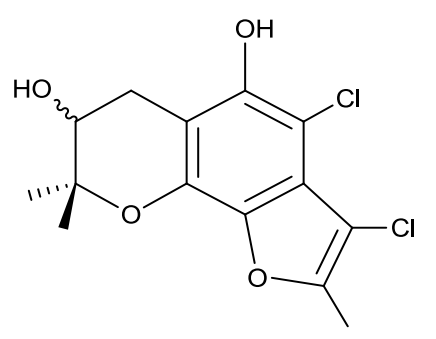

$\mathrm{b}$

Figure 4.3 The structures of compound 4 (a) and chloromycorrhizinol A (b).

The two compounds isolated from $D$. celastrina would appear to be derived from a shikimic acid pathway. Both compounds had moieties resembling that of cinnamic acid. The novel compounds isolated from Seimatosporium sp. resembled polyketides. All three compounds contain propionic acid ring substituents, with compound $\mathbf{8}$ also having a benzoic acid moiety. Propionic acid can be used to extend the cyclization instead of malonate moiety during polyketide synthesis.

Previous studies showed that compounds 1, 2 and $\mathbf{3}$ displayed nematicidal, antibacterial, antifungal and cytotoxic activity. In this study, the minimum inhibitory concentration (MIC) 
observed for compound 1 against $S$. cerevisiae and B. subtilis was $10 \mu \mathrm{g} / \mathrm{mL}(40.3 \mu \mathrm{M})$ (Stadler et al. 1995). MIC values for compounds 2 and 3 were 1 and $2 \mu \mathrm{g} / \mathrm{mL}(3.5 \mu \mathrm{M}$ and $6.3 \mu \mathrm{M})$ respectively against $B$. subtilis. From these studies, mycorrhizin A (2), was the most potent metabolite in comparison to $\left(l^{\prime} Z\right)$-dechloromycorrhizin A (1) and chloromycorrhizin A (3) towards the microbes tested. The sole structural difference between these three compounds lies in their chlorine substitution pattern. The presence of one chlorine atom in the side chain (mycorrhizin A) is seen to increase the bioactivity, whereas adding two chlorine atoms (chloromycorrhizin A) would decrease the potency of the compound (Stadler et al. 1993). Both compounds 5 and $\mathbf{6}$ from $P$. oblonga were shown to be bioactive; phomopsolide A displayed anti-herbivory effects towards elm bark scolytid beetles (Grove 1985).

To assess the antimicrobial properties, each metabolite was tested against the fungal rust $M$. violaceum, a representative ascomycete. M. violaceum (also known as Ustilago violacea) is an obligate fungal rust that causes anther-smut in plant species of the Caryophyllaceae (Hood \& Antonovics 2000; Ruddat et al. 1991). Other microbes used in biological assays were $S$. cerevisiae, the gram negative bacterium E. coli and the gram positive bacterium B. subtilis. Analysis of each compound was carried out in triplicates and at the following three concentrations: 500,50 and $5 \mu \mathrm{M}$. All bioassay data with corresponding $p$ values are summarized in Tables 3.12-3.15. Compounds 1-9 displayed activity against $B$. subtilis at the highest concentration $(500 \mu \mathrm{M})$. Chloromycorrhizin A (3) displayed the highest potency against B. subtilis, having a significantly higher $(p<0.05)$ inhibitory effect at 500 and $50 \mu \mathrm{M}$ in comparison to the positive control chloramphenicol $(500 \mu \mathrm{M})$. Compounds 2, 3, 4 and 9 were active against $B$. subtilis at the lowest tested concentration $(5 \mu \mathrm{M})$ (Table 3.12). 
In the E. coli assay, significant $(p<0.05)$ activity was observed for compounds $\mathbf{2 - 8}$. While compounds 5-8 were only antibacterial against this organism at $500 \mu \mathrm{M}$, the mycorrhizins $\mathbf{2}, \mathbf{3}$ and 4 were antibacterial at the three tested concentrations (Table 3.13). None of the Seimatosporium $s p$. compounds (7-9) demonstrated activity in the $S$. cerevisiae assay. Compounds 2-8 showed significant $(p<0.05$ ) antifungal activity against the yeast at $500 \mu \mathrm{M}$. At $500 \mu \mathrm{M}$, compounds $\mathbf{2}, 3$ and 4 were comparable to the positive control nystatin ( $5 \mu \mathrm{M})$. Only compound 6 displayed activity at $5 \mu \mathrm{M}$ (Table 3.14). Compounds $2,3,4$, as well as 6-9 showed inhibitory activity towards $M$. violaceum. Compound $\mathbf{8}$ did not display any noteworthy activity against the rust at $500 \mu \mathrm{M}$. Because this compound was antifungal at the two lower concentrations, it is postulated that at $500 \mu \mathrm{M}$ a denser solution was observed due to poor shaking and poor dispersal of microbial cells. This would therefore cause a higher than normal OD reading. At $500 \mu \mathrm{M}$ compounds 2 and 4 were comparable to nystatin $(5 \mu \mathrm{M})$. All novel compounds (4 and 7-9) were active against M. violaceum at $5 \mu \mathrm{M}$ (Table 3.15) (see Appendix C for bioassay plots).

The difference observed in the chlorine substitution patterns of the L. papyraceum compound is suspected to play a role in their individual toxicity. It was observed that the more chlorine atoms present in the molecule, the greater the antagonistic effects towards the microbes tested. This could be as a result of the decrease in polarity of these compounds. Greater chlorine substitution, would result in a decrease in polarity. Consequently, less polar molecules could cross the plasma membranes of the microbes more easily and therefore increase the toxic effects observed.

The fact that a Diaporthe $s p$. producing antinsectal compounds was isolated from spruce trees is not unexpected, as spruce trees are susceptible to a wide range of insect pathogens. Studies have provided conclusive evidence illustrating that the rugulosin producing conifer endophytes 
studied in depth in this laboratory can deter non-spruce budworm insects such as the Lambdina fiscellaria (hemlock looper) and Zeiraphera canadensis (spruce budmoth) (Sumarah et al. 2008). It is therefore not implausible that the phomopsolide compounds isolated in this work may also deter herbivorous insects of spruce trees.

Labrador tea plants were once heavily exploited for medicinal purposes. Both the leaves and flowers have been brewed for tea and used in the treatment of a wide array of ailments. This evergreen shrub is said to be allelopathic (Alberta Plant Watch 2015). Allelopathy is the suppression of the growth of neighbouring plants through the production of toxic secondary metabolites. The genus Chrysomyxa is composed of several different species, many of which are pathogenic fungi that cause spruce needle rust. The three most problematic fungal rusts in this genus are C. ledi, C. ledicola and C. weirii (Douglas 2008). These rusts are found in most of the Canadian provinces as well as the United States. Although this disease rarely results in the death of trees, needle rust can cause substantial defoliation and stunted growth; thereby rendering trees unfit for sale (Douglas 2008). C. weirii differs from the other species in this genus as it is as an autoecious rust, meaning it undergoes all life stages within the same host (Crane et al. 2000). By contrast, the heteroecious species C. ledi and C. ledicola alternate between conifers and deciduous hosts to complete their life cycle. A common alternate hosts of these two fungi is the Labrador tea (Douglas 2008). It is possible that the Seimatosporium sp. species harboured in the Labrador tea leaves can potentially confer tolerance to the shrubs by producing these antifungal metabolites. It would be of interest to determine if endophytes can be transferred between both coniferous plants and Labrador tea. In particular, if these antifungal compounds isolated from the Seimatosporium $s p$. strain can confer tolerance towards conifer rusts. 
There are many factors that influence the formation of secondary metabolites. For example, the different nutrients added to the medium in vitro will influence cell metabolism and consequently the metabolites that are produced. Different methods have been established to capture different metabolites. Secondary metabolism in vitro should be carried out under controlled physical conditions (Sumarah \& Miller 2009). Ideally, the conditions have to be as similar as possible both in culture and in planta in order for the production of these chemicals. The fermentation process, as well as the chemical analysis adopted here has been proven to favour the growth of many different fungi and the isolation of a wide variety of secondary metabolites.

Secondary metabolites are related to their respective ecological niche and the metabolic interactions between hosts and endophytes influence metabolite synthesis. In other words, endophytes from different regions can produce different secondary metabolites. Despite the many strains discovered to date, conifer endophytes still remain a largely untapped area of biodiversity. This is aptly illustrated through the constant discovery of novel strains and consequently novel secondary metabolites. The samples here are but a small representation of the true endophyte diversity of conifers in this community. For example, those endophytes that are unculturable or have low competitiveness in comparison to faster growing endophytes would not be represented here.

Carroll (1988) raised an important concept concerning the endophytic mutualism observed in woody trees. As was mentioned, secondary metabolites are produced when fungi undergo duress. In other words, the presence of the endophytes in and of themselves would not prevent pathogenic attacks for an individual plant. For example, in the endophyte - tree - grazer systems addressed in the introduction, trees with these beneficial endophytes can still succumb to herbivory. Instead, what is observed is that as these insects prey on a given tree, endophytes will 
then produce toxins that will deter insects and reduce the population fitness by killing larvae. This reduction in insect populations is what will be beneficial for remaining tree stands, as the devastation suffered by the tree population as a whole would have been reduced. The benefit of endophytes are therefore not restricted to individual trees but to entire populations in a given region.

Another important factor concerning the mutualism between conifers and their endophytes is illustrated by considering the generation of these trees in comparison to that of pathogens. If they manage to evade forest fires and pathogens, conifer trees may live well above 100 years. The genotypes of trees remain unchanged during a generation. In contrast, some insects and pathogenic organisms can complete an entire generation within a year or less. As a result, insects can develop ways to overcome the natural defenses of specific trees, however, the trees cannot afford the timely genetic response needed against these pathogens. The introduction of new or more resistant pathogens (whether insect or fungi) can therefore be quite detrimental to tree hosts. Moreover, conifers only produce a few secondary metabolites in their needles. These metabolites are not sufficient to incur sufficient defense against pathogenic activity. Fungi on the other hand can provide a wide array of secondary metabolites (Miller 1986). By maintaining a mutualist relationship with short-cycle endophytes, trees are equipped with a more efficient defense mechanism towards short-cycle pests (Carroll 1988). Increased tree tolerance would result in healthier forests and consequently a reduction in the funds required for tree protection. Incorporating endophytes that have been shown to have beneficial properties in seedlings is therefore of both ecological and economic interest. 


\section{Conclusion}

A combination of proper siliviculture, using tolerant genotypes where available, and more recently, inoculating seedlings with the right endophytes have been seen to improve reforestation efforts. Identifying beneficial endophytes is therefore a key component in this third step. The aim for this thesis was therefore to screen conifer foliar endophytes for antifungal activity. Endophytes displaying antifungal activity are chosen for further assessing and the secondary metabolites they produce are isolated, characterized and their structures elucidated. Secondary metabolites were isolated from three conifer foliar endophytes: L. papyraceum, D. celastrina and Seimatosporium $s p$. in this thesis. A total of 9 compounds were characterized and identified. From L. papyraceum, ( $\left.1^{\prime} Z\right)$-dechloromycorrhizin A (1), mycorrhizin A (2), chloromycorrhizin A (3) and a novel compound bearing structural similarity to chloromycorrhizin A (4); phomopsolide A (5) and its stable pyrone artefact (6) were isolated from D. celastrina; and finally, 3 compounds (7-9) reported here for the first time from Seimatosporium sp. All compounds displayed inhibitory activity to varying degrees in antifungal and antibacterial assays.

The endophytes isolated during this thesis were found to produce different biologically active secondary metabolites. The isolation of previously known metabolites from different species is useful in two ways. First, new bioactive properties of known compounds can be determined. Second, isolating known compounds can be used as a method of taxonomy classification for novel endophytic fungi. These compounds are not being randomly synthesized and are a product of their biochemical and physical environments. The metabolites isolated during this thesis will be placed in a database to allow for rapid chemical screening and taxa identification of novel 
endophytes. Inoculating conifer seedlings with these endophytes could potentially confer some benefit to the trees. 


\section{References}

Alberta Plant Watch (2015) Labrador Tea Retrieved on 06-08-2015

$<$ http://plantwatchnaturealbertaca/choose-your-plants/labrador-tea/ $>$.

Aly AH, Debbab A, Prokch P (2011) Fungal endophytes: unique plant inhabitants with great promises. Applied Microbioly and Biotechnoly 90:1829-1845.

Anke H, Stadler M, Mayer A, Sterner O (1994) Secondary metabolites with nematicidal and antimicrobial activity from nematophagous fungi and Ascomycetes. Canadian Journal of Botany 73: 932-939.

Arnold AE, Lutzoni F (2007) Diversity and host range of foliar fungal endophytes: are tropical leaves biodiversity hotspots? Ecological Society of America 88: 541-549.

Bacon CW (1995) Toxic endophyte-infected tall fescue and range grasses: historic perspectives. Journal of Animal Science 73: 861-870.

Bertoli A, Ruffoni B, Pistelli L, Pistelli L (2010) Analytical methods for the extraction and identification of secondary metabolite production in 'in vitro' plant cell cultures. Advances in Experimental Medicine and Biology 698: 250-266.

Bouhet JC, Chuong PPV, Toma F, Kirszenbaum M, Fromageot P (1976) Isolation and characterization of luteoskyrin and rugulosin two hepatotoxic anthraquinoids from penicillium islandicum Sopp and Penicillium rugulosum. Journal of Agricultural and Food Chemistry 24: 964-972.

Boyle C, Gotz M, Dammann-Tugend U, Schulz B (2001) Endophyte-host interactions III Local vs systemic colonization. Symbiosis 31: 259-281.

Carroll GC, (1986) "The biology of endophytism in plants with particular reference to woody perennials" In: Fokkema NJ (ed) Van den Heuvel J (ed) Microbiology of the phyllosphere Cambridge, Cambridge University Press. pp 205-222, ISBN 978-0-521-32344-4.

Carroll G (1988) Fungal endophytes in stems and leaves: From latent pathogen to mutualistic symbiont. Ecology 69: 2-9.

Clay K (1988) "Grass endophytes" In Fokkema NJ (ed) Van den Heuvel J (ed) Microbiology of the phyllosphere Cambridge, Cambridge University Press. pp 188-204, ISBN 978-0-521-32344-4.

Clay K, Holah J (1999) Fungal endophyte symbiosis and plant diversity in successional fields. Science 285: $1742-1745$.

Clay K, Schardl C (2002) Evolutionary origins and ecological consequences of endophyte symbiosis with grasses. The American Naturalist 160: 99- 127. 
Crane PE, Hiratsuka Y, Currah RS (2000) Reproductive biology and evidence for water dispersal of teliospores in Chrysomyxa weirii a microcyclic spruce needle rust. Mycologia 92: 754-763.

Deacon JW (2005) Fungal biology, $4^{\text {th }}$ ed. Chap. 7: "Fungal metabolism and fungal products", WileyBlackwell. pp.122-141, ISBN: 978-1-4051-3066-0

Deckert RJ, Hsiang T, Peterson RL (2002) Genetic relationships of endophytic Lophodermium nitens isolates from needles of Pinus strobus. Mycolical Research 106: 305-313.

Ding X, Liu K, Deng B, Chen W, Li W Liu F (2013) Isolation and characterization of endophytic fungi from Camptotheca acuminate. World Journal of Microbiology and Biotechnoly 29:18311838 .

Diogo ELF, Santos JM, Phillips AJL (2010) Phylogeny morphology and pathogenicity of Diaporthe and Phomopsis species on almond in Portugal. Fungal diversity 44: 107-115.

Douglas SM (2008) Spruce needle rusts The Connecticut Agricultural Experiment Station Retrieved on $06-08-2015$

$<$ http://wwwctgov/caes/lib/caes/documents/publications/fact sheets/plant pathology and ecolo gy/sruce_needle_rusts_06-27-08rpdf $>$.

Et-touil K, Bernier L, Beaulieu J, Berube JA, Hopkin A, Hamelin RC (1999) Genetic structure of Cronartium ribicola populations in eastern Canada. Ecology and Population Biology 89: 915919.

Ferreira RB, Monteiro S, Freitas R, Santos CN, Chen Z, Batista LM, Duarte J, Borges A, Teixeteira AR (2006) Fungal Pathogens: The battle for plant infection. Critical Reviews in Plant Sciences 25: 505-524.

Frasz SL (2014) The development and comparison of quantitative PCR assays and enzyme-linked immunosorbent assays as rapid detection methods for specific foliar endophytes (M.Sc.) Carleton University Ottawa.

Frasz S, Walker AK, Nsiama TK, Adams GW, Miller JD (2014) Distribution of the foliar fungal endophyte Phialocephala scopiformis and its toxin in the crown of a mature white spruce tree as reavealed by chemical and qPCR analyses. Canadian Journal of Forest Research 44: 1138-1143.

Fravel DR (1988) Role of antibiosis in the biocontrol of plant diseases. Annual Review of Phytopathology 26:75-91.

Frederick ZA, Villani S, Cox KD (2011) First report of white pine blister rust caused by Cronartium ribicola on immune black currant Ribes nigrum Cv Titania in Preston Connecticut APSnet 95: 15891.

Ganley RJ, Brunsfeld SJ, Newcombe G (2004) A community of unknown endophytic fungi in western white pine. PNAS Ecology 101: 10107-10112. 
Ganley RJ, Sniezko RA, Newcombe G (2008) Endophyte-mediated resistance against white pine blister rust in Pinus monticola. Forest Ecology and Management 255: 2751-2760.

Gomes RR, Glienke C, Videira SIR, Lombard L, Groenewald JZ, Crous PW (2013) Diaporthe: a genus of endohpytic saprobic and plant pathogenic fungi. Persoonia 31: 1-41.

Grove JF (1985) Metabolic products of Phomopsis oblonga Part 2 Phomopsolide A and B Tiglic esters of two 6-substituted 56-dihydro-5-hydroxypyran-2-ones. Journal of the Chemical Society Perkin Transactions 1: 865-869.

Harvey AE, Grasham JL (1970) Survival of Cronartium ribicola on a medium containing host tissue culture diffusates. Mycopathologia et mycologia applicate 40: 245-248.

Hood ME, Antonovics J (2000) Intratetrad mating heterozygosity and the maintenance of deleterious alleles in Microbotryum violaceum (=Ustilago violacea). Heredity 85: 231-241.

Hunt RS (1983) White pine blister rust in British Columbia II Can stands be hazard rated? The Forestry Chronicle pp 30-33.

Hunt RS, von Rudloff E (1974) Chemosystematic studies in the genus Abies 1 Leaf and twig oil analysis of alpine and balsam firs. Canadian Journal of Botany 52: 477-487.

Hunt RS, von Rudloff E (1977) Leaf-oil-terpene variation in western white pine populations of the Pacific Northwest. Forest Science 23: 507-516.

Johnson JA, Whitney NJ (1989) A study of fungal endophytes of needles of balsam fir (Abies balsamea) and red spruce (Picea rubens) in New Brunswick Canada using culture and electron microscope techniques. Canadian Journal of Botany 67: 3513-3516.

Johnson JA, Whitney NJ (1992) Isolation of fungal endophytes from black spruce (Picea mariana) dormant buds and needles from New Brunswick Canada. Canadian Journal of Botany 70: 17541757.

Keller NP, Turner G, Bennett JW (2005) Fungal secondary metabolism-from biochemistry to genomics. Natural Reviews Microbiology 3: 937-947.

Kralova K, Jampilek J, Ostrovsky I (2012) Metabolomics-useful tool for study of plant responses to abiotic stresses. Ecological Chemistry and Engineering S 19: 133-161.

Kriebel HB (1983) Breeding eastern white pine: A world perspective. Forest Ecology and Management 6: 263-279.

Larkin BG, Hunt LS, Ramsey PW (2012) Foliar nutrients shape fungal endophyte communities in Western white pine (Pinus monticola) with implications for white-tailed deer herbivory. Fungal Ecology 5:252-260. 
Magan N, Smith MK (1996) Isolation of the endophytes Lophodermium piceae and Rhizosphaera kalkhoffii from Sitka spruce needles in poor and good growth sites and in vitro effects of environmental factors. Phyton 36: 103-110.

Maloy OC (1997) White pine blister rust control in North America: A case history. Annual Review of Phytopathology 35: 87-109.

Miller JD, Mackenzie S, Foto M, Adams GW, Findlay JA (2002) Needles of white spruce inoculated with rugulosin-producing endophytes contain rugulosin reducing spruce budworm growth rate. Mycological Research 106: 471-479.

Miller JD, Sumarah MW (2008) Effect of a rugulosin-producing endophyte in Picea glauca on Choristoneura fumiferana. Journal of Chemical Ecology 34: 362-368.

Miller JD (1986) "Toxic metabolites of epiphytic and endophytic fungi of conifer needles" In: Fokkema NJ (ed) Van den Heuvel J (ed) Microbiology of the phyllosphere Cambridge, Cambridge University Press. pp 223-231, ISBN 978-0-521-32344-4.

Miller JD (2011) Foliar endophytes of spruce species found in the Acadian Forest: Basis and potential for improving the tolerance of the forest to spruce budworm. Endophytes of Forest Trees: Biology and Applications 80: 237-249.

Natural Resources Canada (2012) White pine blister rust Retrieved on 15-11-2013

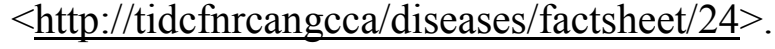

Northern Ontario Plant Database Rhododendron groenlandicum Retrieved on 06-08-2015 $<\underline{\text { http://wwwnorthernontariofloraca/descriptioncfm?speciesid }=1000637}>$.

Pavia DL, Lampman GM, Kriz GS (2001) Introduction to spectroscopy $3^{\text {rd }}$ ed. Brooks/Cole Thompson learning Inc. pp 217-233 ISBN 0-03-031961-7.

Pavia DL, Lampman GM, Kriz GS, Vyvyan JR (2009) Introduction to spectroscopy $4^{\text {th }}$ ed. Brooks/Cole Cengage learning Inc. pp 233-246 ISBN 0-495-11478-2.

Richardson SN (2014) Isolation and characterization of bioactive metabolites from endophytic fungi of Pinus strobus (M.Sc.) Carleton University Ottawa.

Richardson SN, Nsiama TK, Walker AK, McMullin DR, Miller JD (2015) Antimicrobial dihydrobenzofurans and xanthenes from foliar endophyte of Pinus strobus. Phytochemistry 117: 436-443.

Richardson SN, Walker AK, Nsiama TK, McFarlane J, Sumarah MW, Ibrahim A, Miller JD (2014) Griseofulvin-producing Xylaria endophytes of Pinus strobus and Vaccinium angustifolium: evidence for a conifer-understory species endophyte ecology. Fungal Ecology 11: 107-113. 
Robinson JA (1991) Polyketide synthase complexes: their structure and function in antibiotic biosynthesis. Philosophical Transactions of the Royal Society London B 332: 107-114.

Rodriguez RJ, White Jr JF, Arnold AE, Redman RS (2008) Fungal endophytes: diversity and functional role. New Phytologist Tansley review pp1-17.

Royama T (1984) Population dynamics of the spruce budworm Choristoneura Fumiferana. Ecological Monographs 54: 429-462.

Ruddat M, Kokontis J, Birch L, Garber ED, Chiang KS, Campanella J, Dai H (1991) Interactions of Microbotryum violaceum (Ustilago violacea) with its host plant Silene alba. Plant Science 80: 157-165.

Saikkonen K, Faeth SH, Helander M, Sullivan TJ (1998) Fungal endophytes: A continuum of interactions with host plants. Annual Review of Ecology and Systematics 29: 319-343.

Schulz B, Sucker J, Aust HJ, Krohn K, Ludewig K, Jones PG, Doring D (1995) Biologically active secondary metabolites of endophytic Pezicula species. Mycological Research 99: 1007-1015.

Schulz B, Boyle C, Draegger S, Rommert AK, Krohn K (2002) Endophytic fungi: a source of novel biololgically active secondary metabolites. Mycological Research 106: 996-1004.

Sieber TN (2007) Endophytic fungi in forest trees: are they mutualists? Fungal Biology Reviews 21: 75-89.

Stadler M, Anke H, Shan R, Sterner O (1995) New metabolites with nematicidal and antimicrobial activities from the Ascomycete Lachnum papyraceum (Karst) Karst VI Structure determination of non-halogenated metabolites structurally related to Mycorrhizin A. Journal of Antibiotics 48: 154-157.

Stadler M, Anke H, Sterner O (1994) New metabolites with nematicidal and antimicrobial activities from the Ascomycete Lachnum papyraceum (Karst) Karst IV Structural elucidation of novel isocoumarin derivatives. Journal of Antibiotics 48: 267-270.

Stadler M, Anke H, Arendholz WR, Hansske F, Anders U (1993) Lachnumon and lachnumol A new metabolites with nematicidal and antimicrobial activities from the Ascomycete Lachnum papyraceum (Karst) Karst I Producing organism fermentation isolation and biological activities. Journal of Antibiotics 46: 961-967.

Stadler M, Anke H, Sterner O (1993a) Metabolites with nematicidal and antimicrobial activities from the Ascomycete Lachnum papyraceum (Karst) Karst V Production isolation and biological activities of bromine-containing mycorrhizin and lachnumon derivatives and four additional new bioactive metabolites. Journal of Antibiotics 48: 149-153. 
Stefani FOP, Berube JA (2006) Evaluation of foliar fungal endophyte incidence in field-grown transgenic Bt white spruce trees. Canadian Journal of Botany 84: 1573-1580.

Stefani FOP, Berube JA (2006a) Biodiversity of foliar fungal endophytes in white spruce (Picea glauca) from Southern Quebec. Canadian Journal of Botany 84: 777-790.

Stone JK (1987) Initiation and development of latent infections by Rhabdocline parkeri on Douglas-fir. Canadian Journal of Botany 65: 2614-2621.

Sumarah MW, Adams GW, Berghout J, Slack GJ, Wilson AM, Miller JD (2008) Spread and persistence of a rugulosin-producing endophyte in Picea glauca seedlings. Mycological Research 112: 731-736.

Sumarah MW, Miller JD (2009) Anti-insect secondary metabolites from fungal endophytes of conifer trees. Natural Products Communications 4: 1497-1504.

Sumarah MW, Miller JD Adams GW (2005) Measurement of a rugulosin-producing endophyte in white spruce seedlings. Mycologia 97: 770-776.

Sumarah MW, Kesting JR, Sorensen D, Miller JD (2011) Antifungal metabolites from fungal endophytes of Pinus strobus. Phytochemistry 72: 1833-1837.

Sumarah MW, Puniani E, Blackwell B, Miller JD (2008) Characterization of polyketide metabolites from foliar endophytes of Picea glauca. Journal of Natural Products 71: 1393-1398.

Sumarah MW, Walker AK, Seifert KA, Todorov A, Miller JD (2015) Screening of fungal endophytes isolated from eastern white pine needles Recent Adv. Phytochemistry 45 (in press).

Tanguay P (2013) Agricultural and forest stakeholders: on the alert! Emergence of a new strain of white pine blister rust Natural Resources Canada Canadian Forest Service Laurentian Forestry Centre. ISBN 978-1-100-22067-3.

Terry LA, Joyce DC (2004) Elicitors of induced disease resistance in postharvest horticultural crops: a brief review. Postharvest Biology and Technology 32: 1-13.

Trofast J (1978) Chloromycorrhizinol A a furochroman from an isolate of the roots of Monotropa hypoitys. Phytochemistry 17: 1359-1361.

Trofast J, Wickberg B (1976) Mycorrhizin A and chloromycorrhizin A two antibiotics from a mycorrhizal fungus of Monotropa hypopitys. L Tetrahedron 33: 875-879.

US Environmental Protection Agency (2006) Pesticides: Reregistration Retrieved on 2013-01-12 $<$ http://wwwepagov/oppsrrd1/REDs/factsheets/triadimefon_triadimenol_fshtm $>$.

Vermont Invasives Mutated fungus troubles forestry officials (2013) Retrieved on 2013-11-15 $<\underline{\text { http://wwwvtinvasivesorg/news/mutated-fungus-troubles-forestry-officials }>}$. 
Vincent JG, Vincent HW (1944) Filter paper disc modification of the Oxford cup penicillin determination. Proceedings of the Society for Experimental Biology and Medicine 55: 162-164.

Weber J (1981) A natural control of Dutch elm disease. Nature (London) 292: 449-451. 


\section{Appendix}

\section{A: Identification of the strains grown in bulk}

\section{Lachnum papyraceum (NB-175-2)}

Isolated from surface sterilized Picea rubens on ground with fruit body, Albright's Corner (north of Gagetown), NB

ITS sequence:

CATTACAGAGTTCATGCCCTTCGGGGTAGATCTCCCACCCTTGTGTATCATTATAGA ATGTTGCTTTGGCGGGCCGCGCCTCGTGCGCCTAGATTTGCGTCTAGCGTGCCCGCC AGAGGACCCCCTAAACTCTGAATGTTAGTGTCGTCTGAGTACTATTAAATAGTTAAA ACTTTCAACAACGGATCTCTTGGTTCTGGCATCGATGAAGAACGCAGCGAAATGCGA TAAGTAATGTGAATTGCAGAATTCAGTGAATCATCGAATCTTTGAACGCACATTGCG CCCCCTGGTATTCCGGGGGGCATGCCTGTTCGAGCGTCATTTATACCAATCTAGCCT GGCTAGGTGTTGGGCTTCGCCGTCTGGCGGGCCTTAAAACTAGTGGCGGTGCTCTTA GGCTCTACGCGTAGTAATTTTCTCGCTATAGGGTCCTGGGAGATGCTGGCCAGCAAC CCCAAATTTTTCTAGGTTGACCT

\section{Diaporthe cf celastrina (AW 545)}

KAS5254 Diaporthe cf celastrina (99\% match with GenBank KC343047 CBS 139.27 Diaporthe celastrina). Isolated from surface sterilized living red spruce needle (Picea rubens), Basin $\mathrm{Rd}$, Lepreau NB

ITS sequence:

AATTTTCAGAAGTTGGGGGGTTTAACGGCAGGGCACCGCCAGGGCCTTCCAAAGCG AGGGTTTAACTACTGCGCTCGGGGTCCTGGCGAGCTCGCCACTGAATTTCAGGGCCT GCTTTTGGGTAAAAGCAGTGCCCCATCACCAAGCCAGGCTTGAGGGTTGAAATGAC GCTCGAACAGGCATGCCCTCCGGAATACCAGAGGGCGCAATGTGCGTTCAAAGATT CGATGATTCACTGAATTCTGCAATTCACATTACTTATCGCATTTCGCTGCGTTCTTCA TCGATGCCAGAACCAAGAGATCCGTTGTTGAAAGTTTTGATTCATTTATGTTTTATTC TCAGAGTTTCAGTGTAAAAACAAGAGTTAGGTTGGCCGCCGGCGGGCCGTCTCAAC ACCCGAGGGTGAGGGGCCCCGAAGGACCAGCTAGCGCCGAGGCAACAGTAAGGTA TAAGTTCACAAAGGGTTTCTGGGTGCGCCTGGGGCGCGTTCCAGCAATGATCCCTCC GCTGGTTCACCAACGGAGACCT 


\section{Seimatosporium sp. (NB 330 AW584)}

Seimatosporium foliicola 95/99 AB594802.1 Isolated from Labrador tea Rhododendron groenlandicum, Lepreau NB

ITS sequence:

CATTACAGAGTTATCTAACTCCCAAACCCATGTGAACTTACCATTGTTGCCTCGGCA GAGCCTACCCGGTACCTACCCTGGAGCAGCTACCCTGTAGCTACCCTGGAGCGGTTA CCCTGTAGCGTTTTGCCGGTGGACTTTTAAACTATTGTTATTTTATTGTTATCTGAGC GTCTTATTTTAATAAGTCAAAACTTTCAACAACGGATCTCTTGGTTCTGGCATCGATG AAGAACGCAGCGAAATGCGATACGTAATGTGAATTGCAGAATTCAGTGAATCATCG AATCTTTGAACGCACATTGCGCCCATTAGTACTCTAGTGGGCATGCCTGTTCGAGCG TCATTTCAACCCTTAAGCCTAGCTTAGTATTGGGACTTTACTTTCGAGTAATTCCTCA AATCCAACGGCGGATCTGTGGTATCCTCTGAGCGTAGTAATTTTTATCTCGCTTTTGT TAGGTGCTGCAGCTCCCAGCCGCTAAACCCCCAATTTTTTAATGGTTGACCT 


\section{B: Spectroscopic data for compounds 1-9}

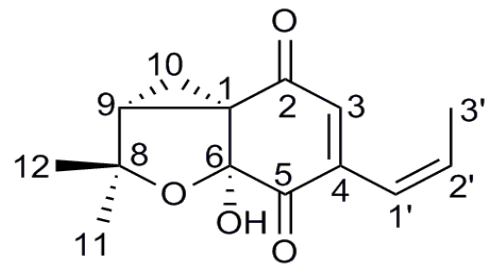

${ }^{1} \mathrm{H}$ NMR spectrum of (1 'Z)- dechloromycorrhizin A (1) (400 MHz, $\left.\mathrm{CD}_{3} \mathrm{OD}\right)$

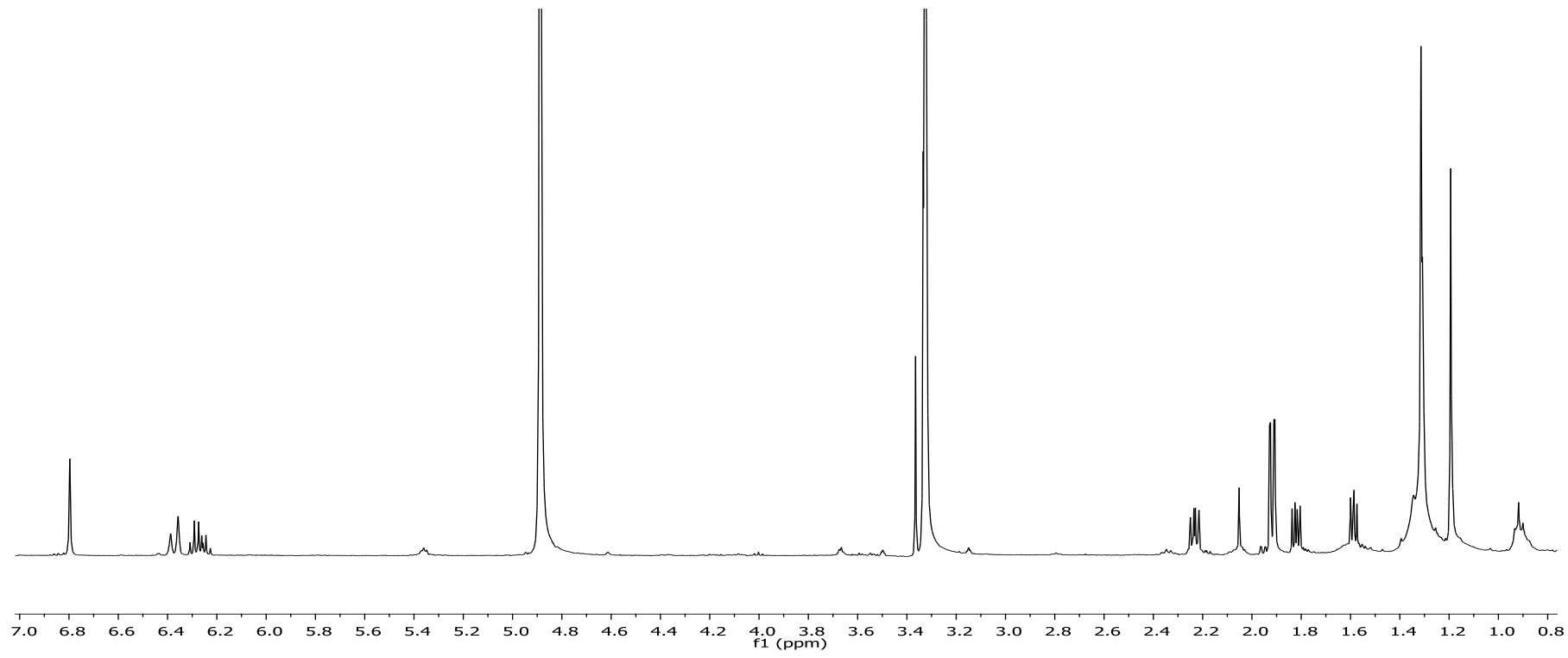

${ }^{13} \mathrm{C}$ NMR spectrum of ( $\left.1^{\prime} Z\right)$ - dechloromycorrhizin A (1) (100 MHz, $\left.\mathrm{CD}_{3} \mathrm{OD}\right)$

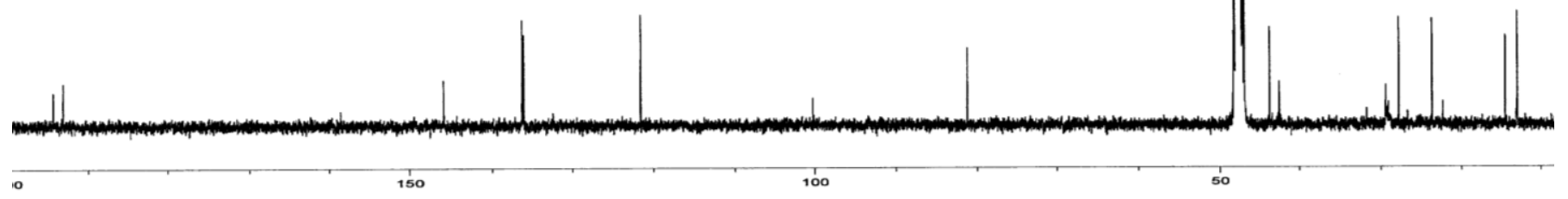


<smiles>C/C=C(/Cl)C1=CC(=O)[C@@]23C[C@H](C)O[C@]2(C)C(=O)C13O</smiles>

${ }^{1} \mathrm{H}$ NMR spectrum of mycorrhizin A (2) (400 MHz, CD $\left.{ }_{3} \mathrm{OD}\right)$

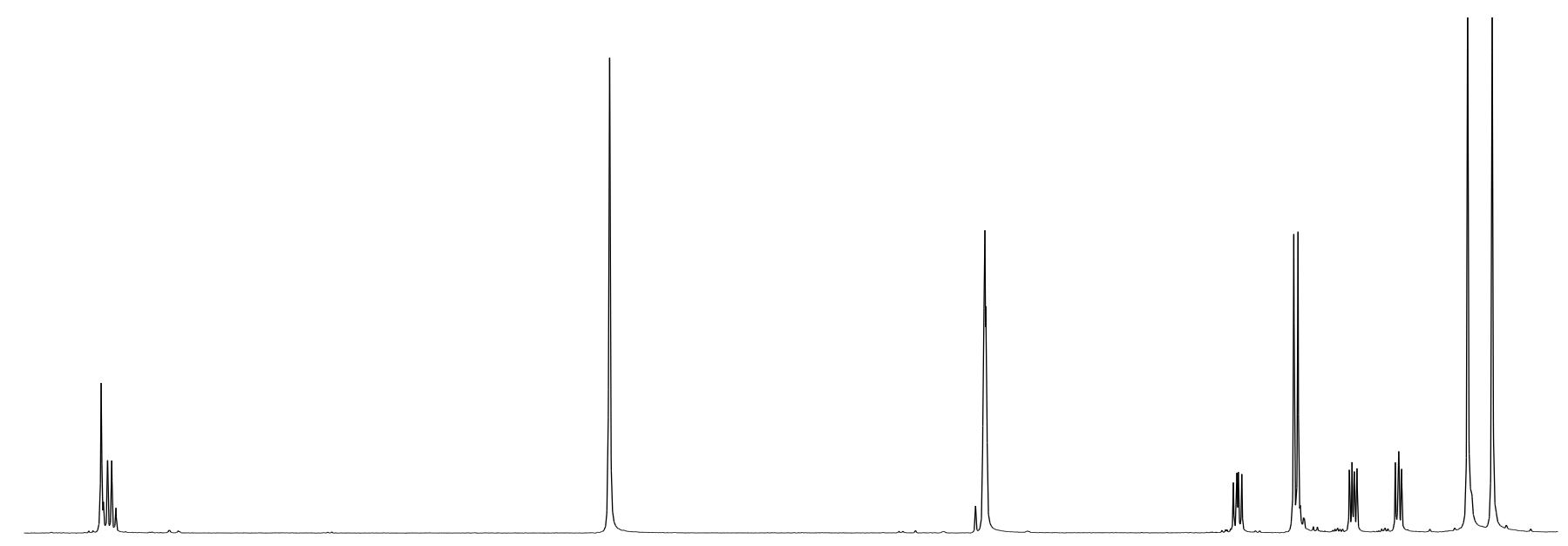

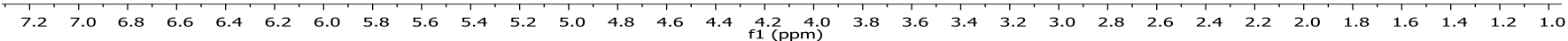

${ }^{13} \mathrm{C}$ NMR spectrum of mycorrhizin $\mathrm{A}(2)\left(100 \mathrm{MHz}, \mathrm{CD}_{3} \mathrm{OD}\right)$
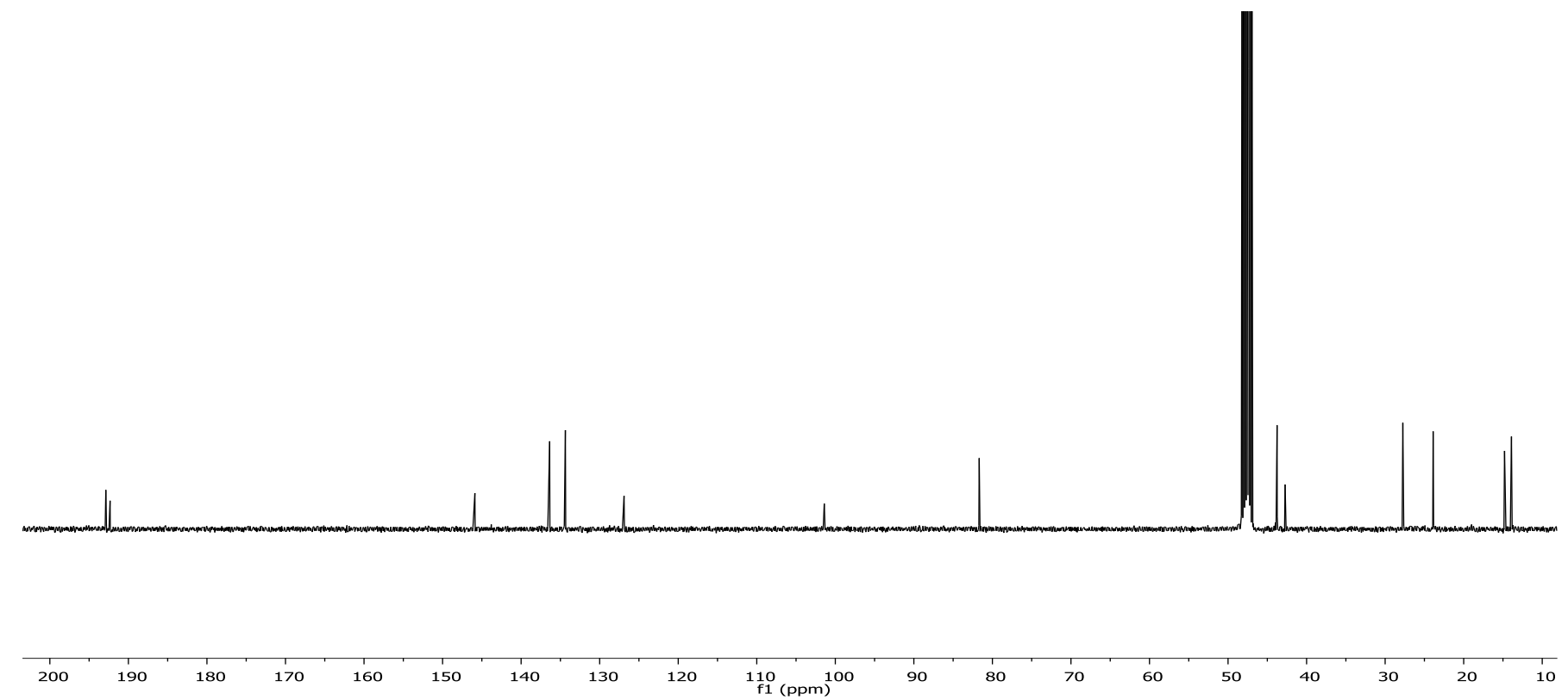
<smiles></smiles>

${ }^{1} \mathrm{H}$ NMR spectrum of chloromycorrhizin A (3) (400 MHz, $\left.\mathrm{CD}_{3} \mathrm{OD}\right)$

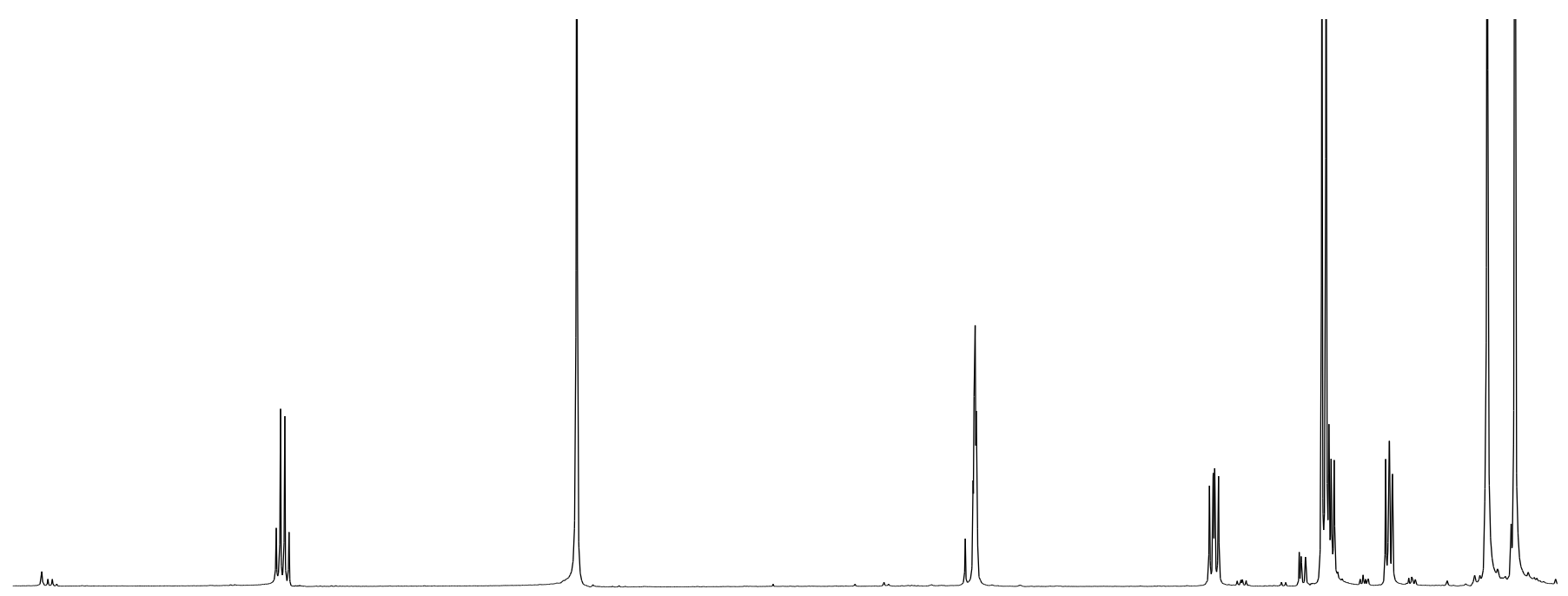

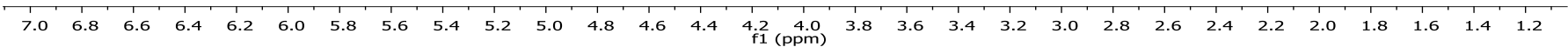

${ }^{13} \mathrm{C}$ NMR spectrum of chloromycorrhizin $\mathrm{A}(3)$ (100 MHz, $\mathrm{CD}_{3} \mathrm{OD}$ )
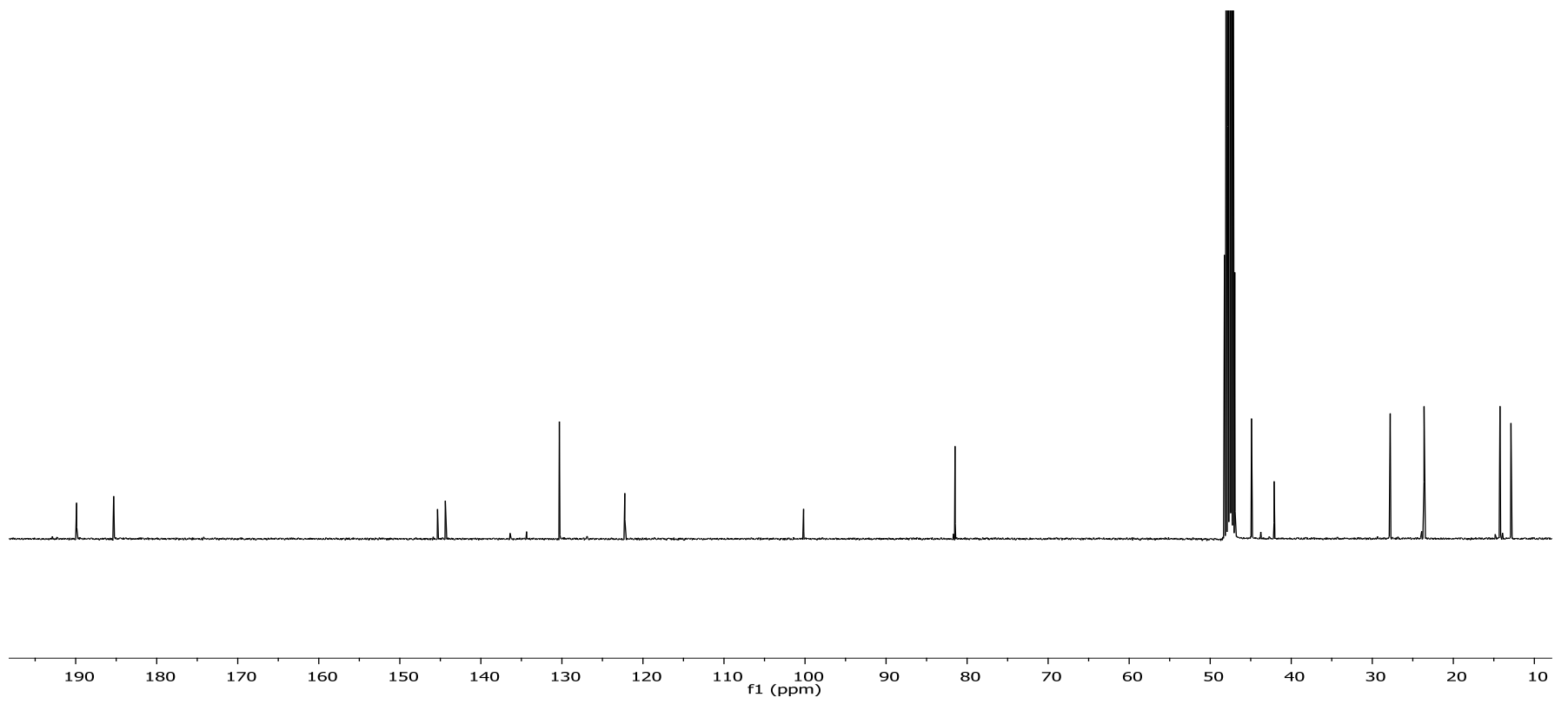
HPLC chromatogram of compounds 1-3.

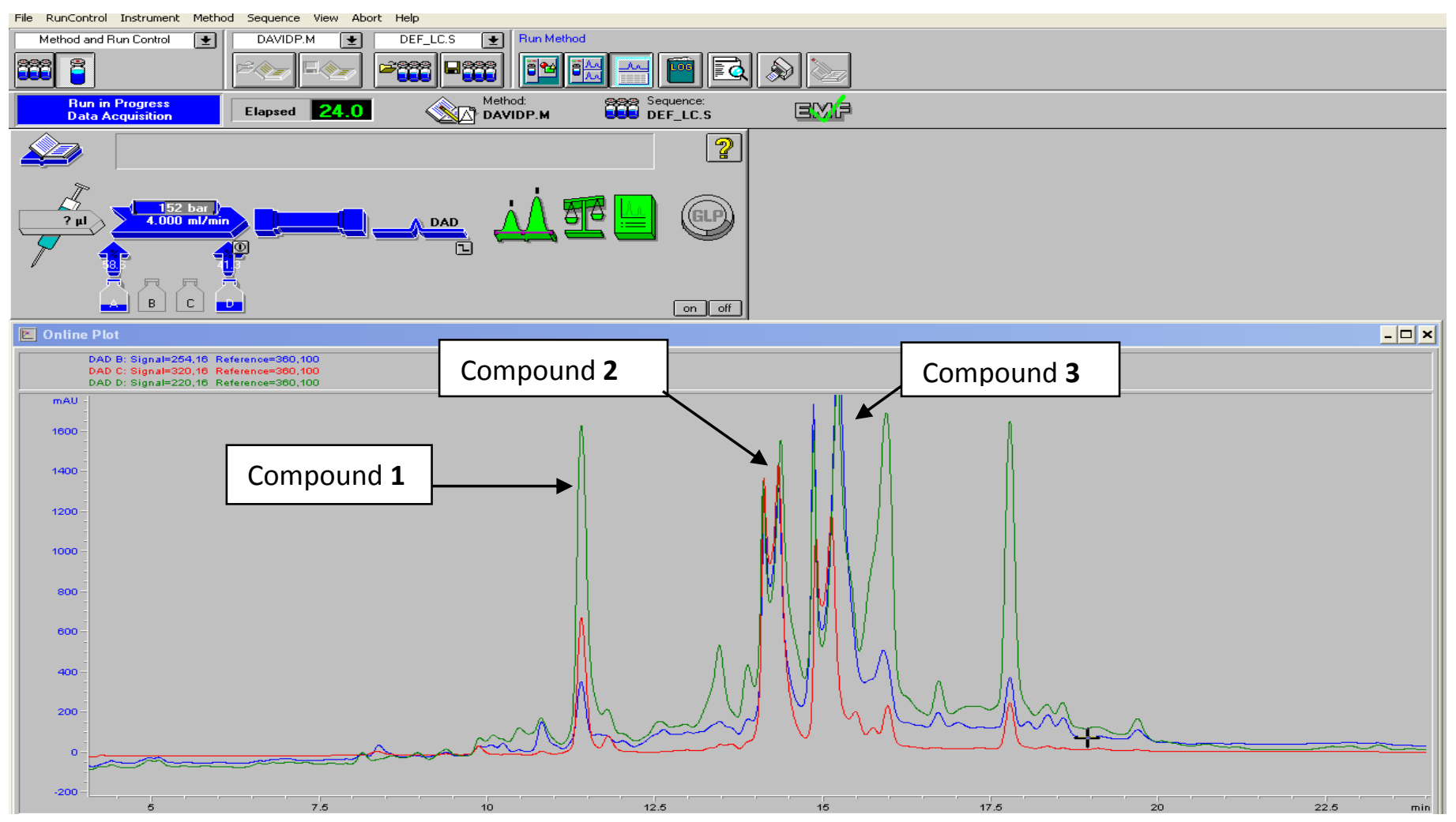

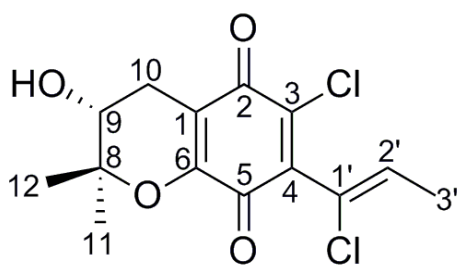

ESI-MS mass spectrum $(\mathrm{m} / \mathrm{z})$ data for compound 4

\section{NPF3-9-1-pure}

NPF3-9-1-pure 264 (8.873)

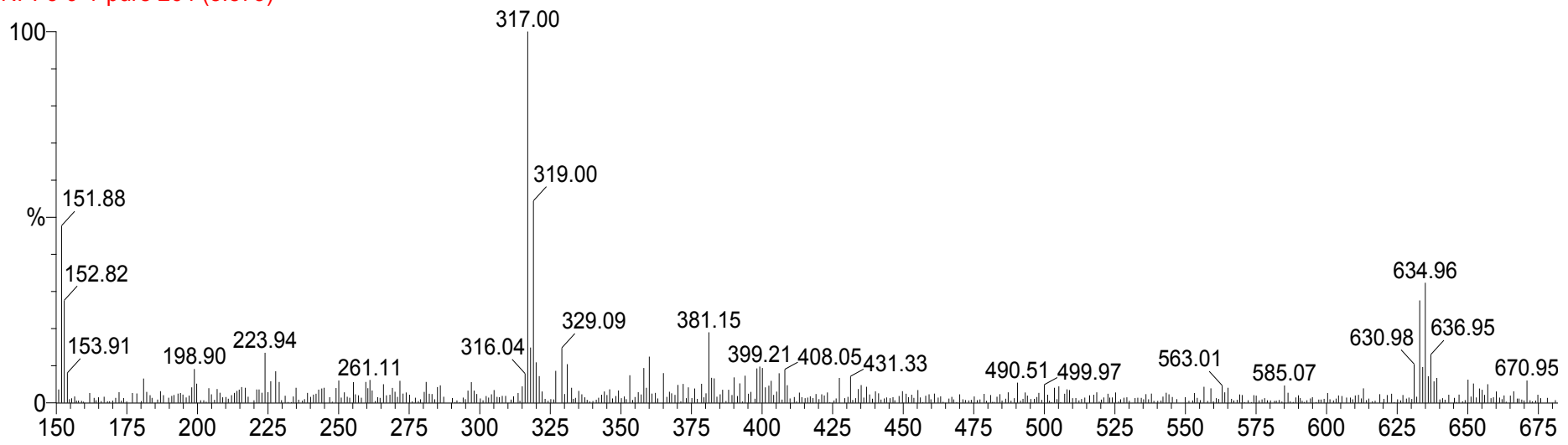


${ }^{1} \mathrm{H}$ NMR spectrum of compound $4\left(400 \mathrm{MHz}, \mathrm{CD}_{3} \mathrm{OD}\right)$

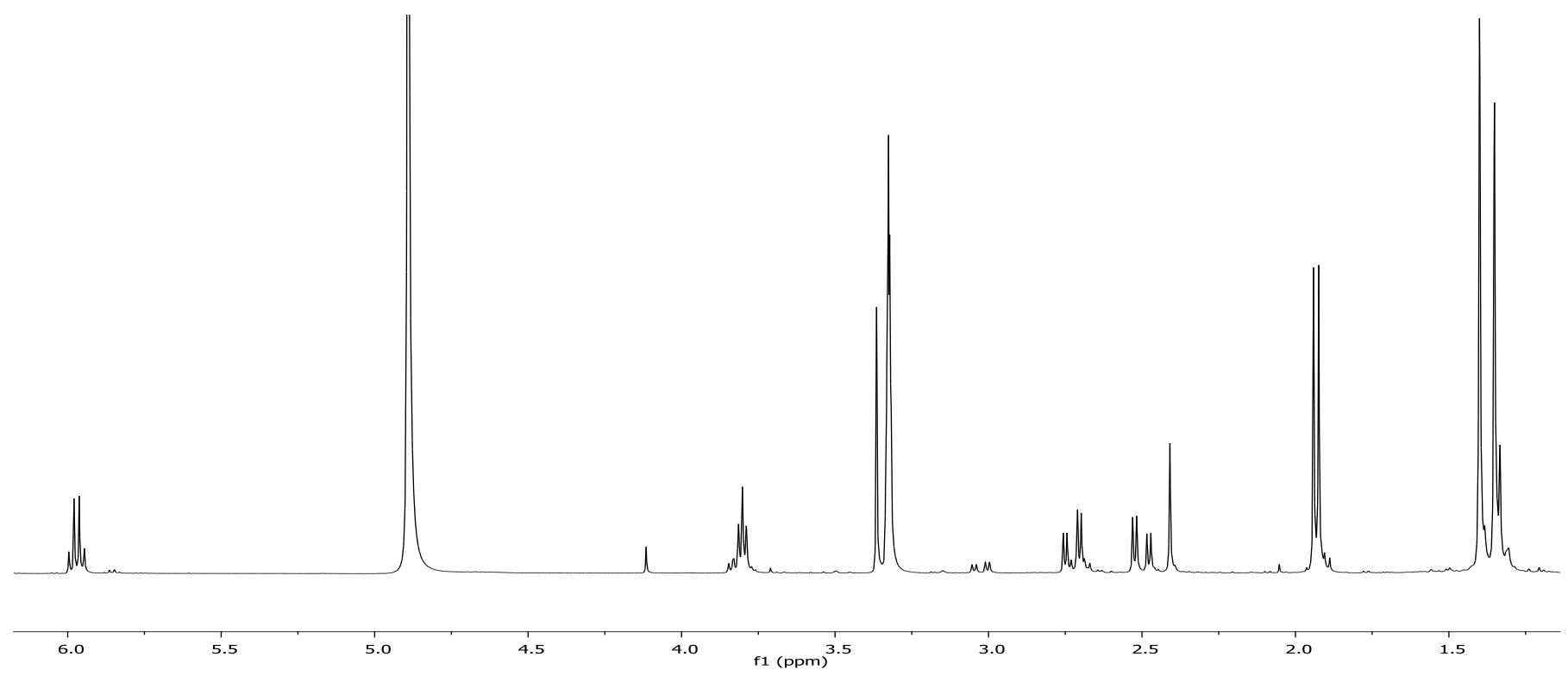

${ }^{13} \mathrm{C}$ NMR spectrum of compound $4\left(100 \mathrm{MHz}, \mathrm{CD}_{3} \mathrm{OD}\right)$

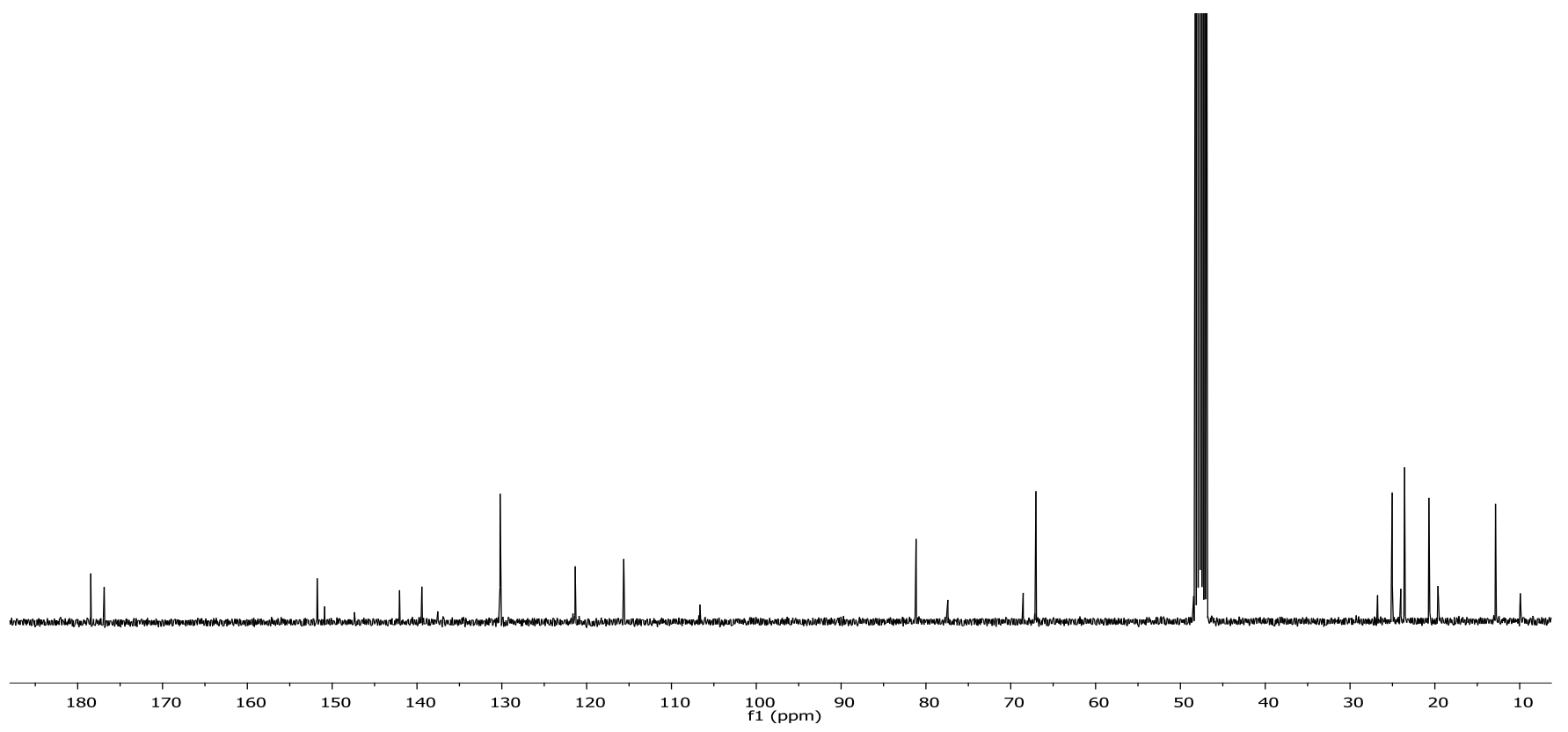




\section{HPLC chromatogram of compound 4.}

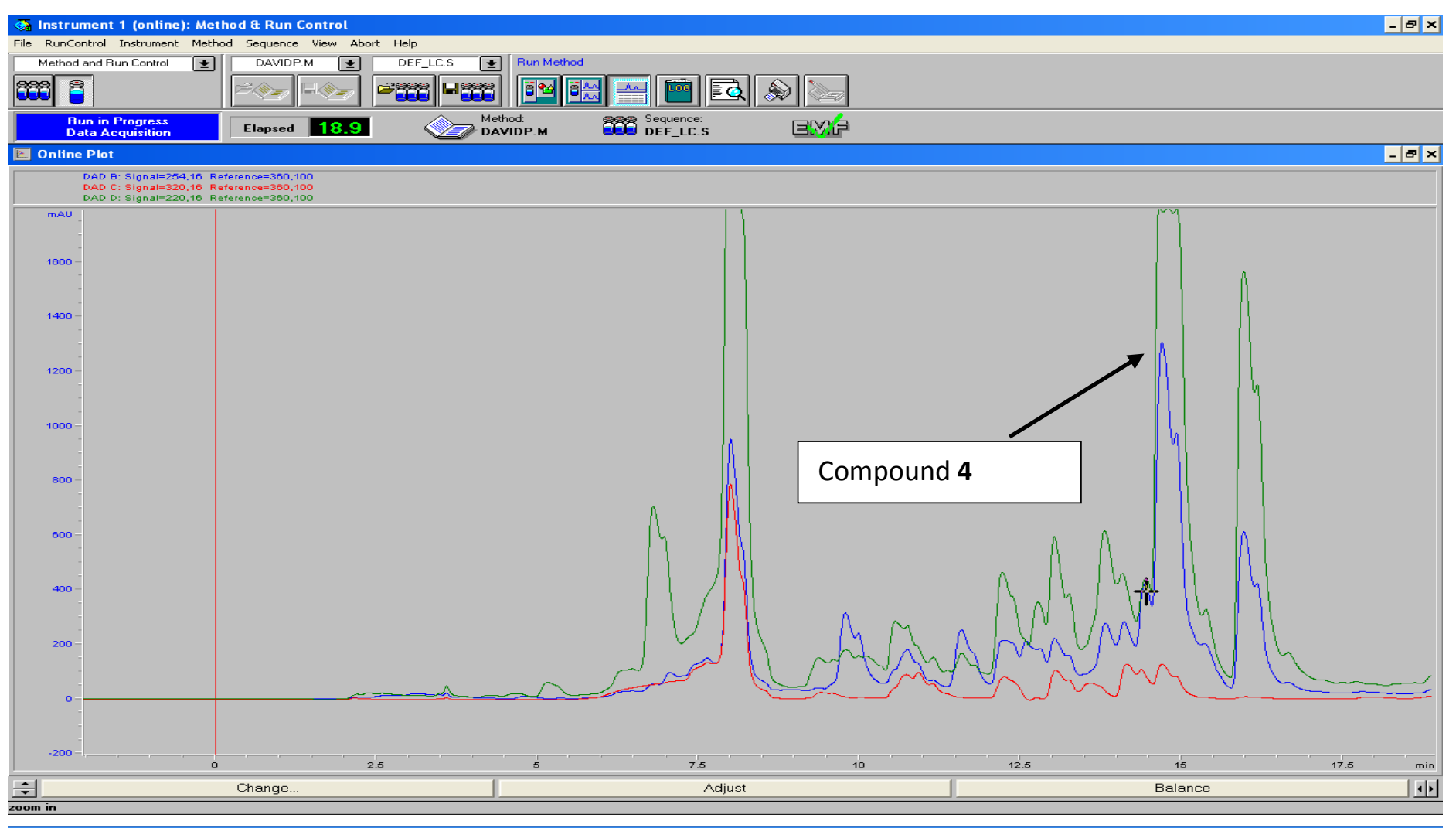




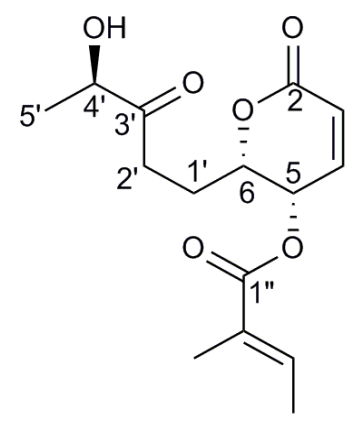

${ }^{1} \mathrm{H}$ NMR spectrum of phomopsolide A (5) (400 MHz, $\left.\mathrm{CD}_{3} \mathrm{OD}\right)$

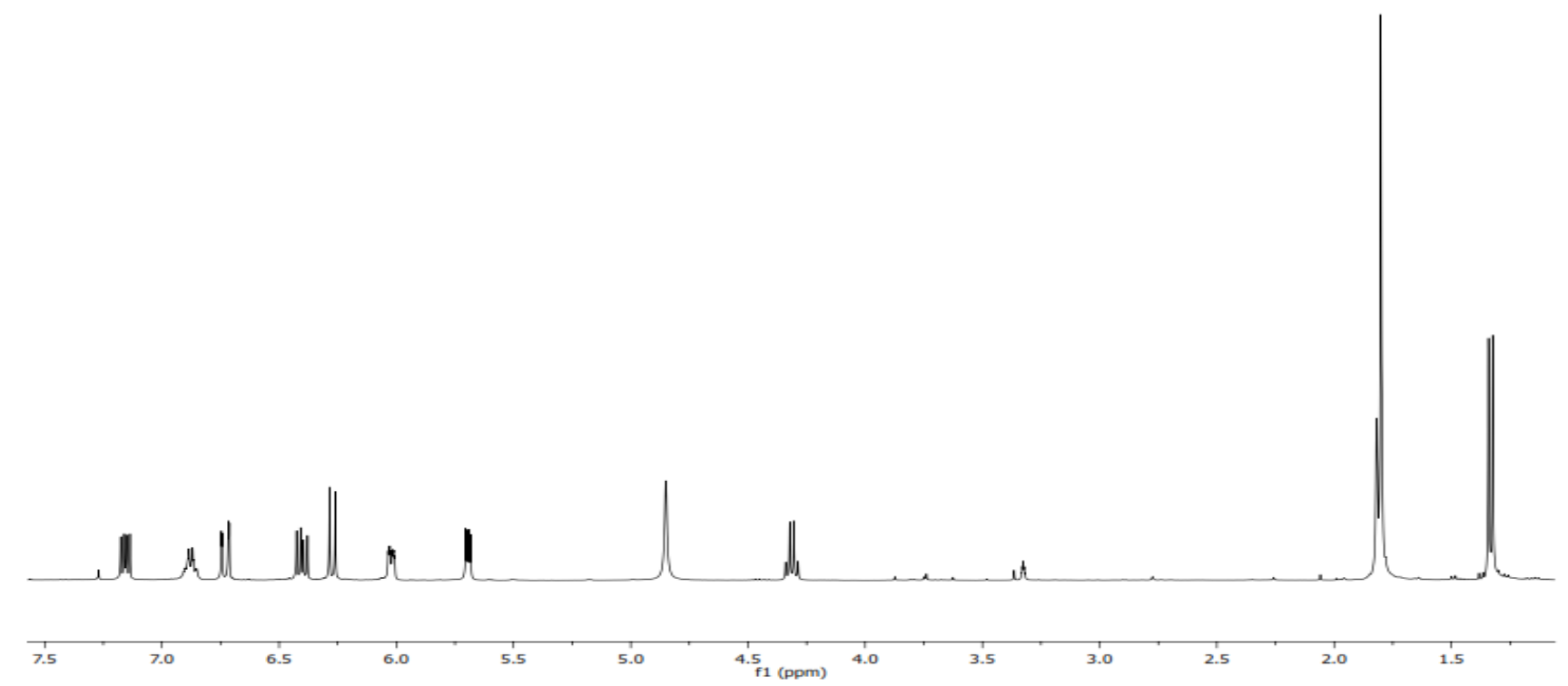

${ }^{13} \mathrm{C}$ NMR spectrum of phomopsolide A (5) (100 MHz, $\left.\mathrm{CD}_{3} \mathrm{OD}\right)$

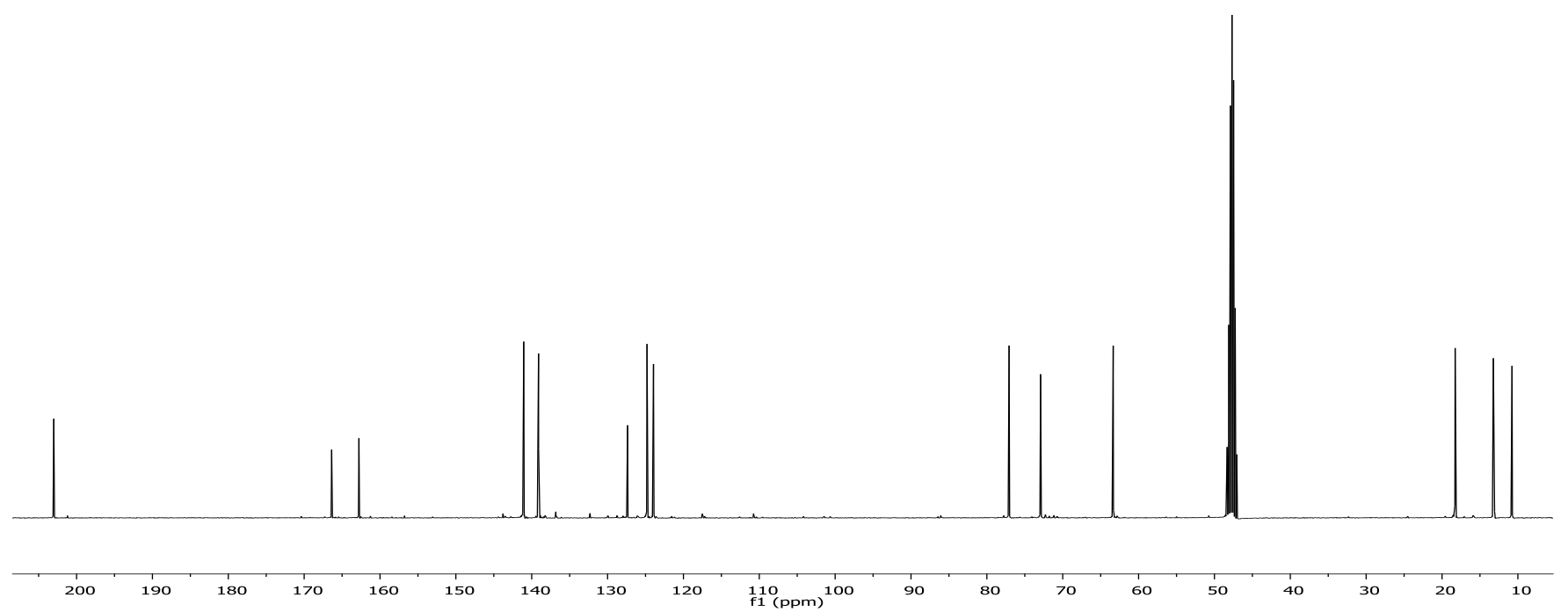




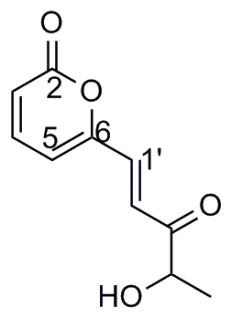

${ }^{1} \mathrm{H}$ NMR spectrum of C10 pyrone (6) (400 MHz, $\left.\mathrm{CD}_{3} \mathrm{OD}\right)$
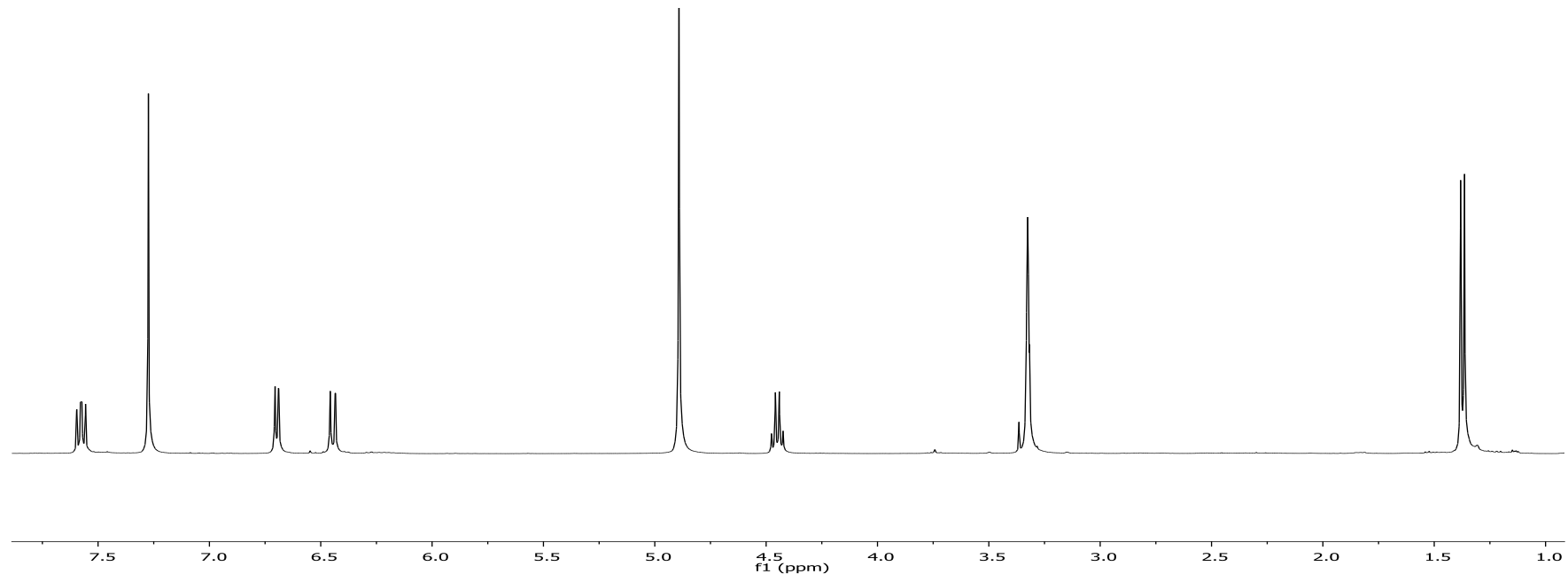

${ }^{13} \mathrm{C}$ NMR spectrum of C10 pyrone (6) (100 MHz, $\left.\mathrm{CD}_{3} \mathrm{OD}\right)$
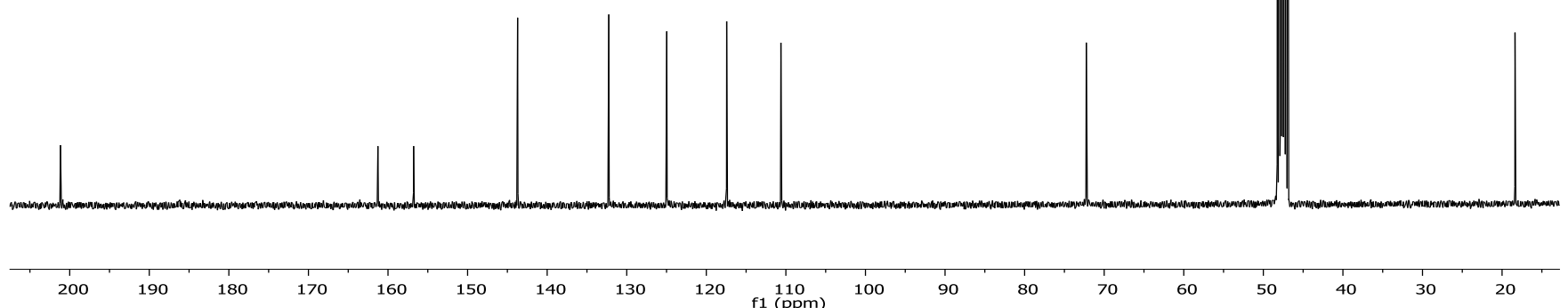
HPLC chromatogram of compound 6 .

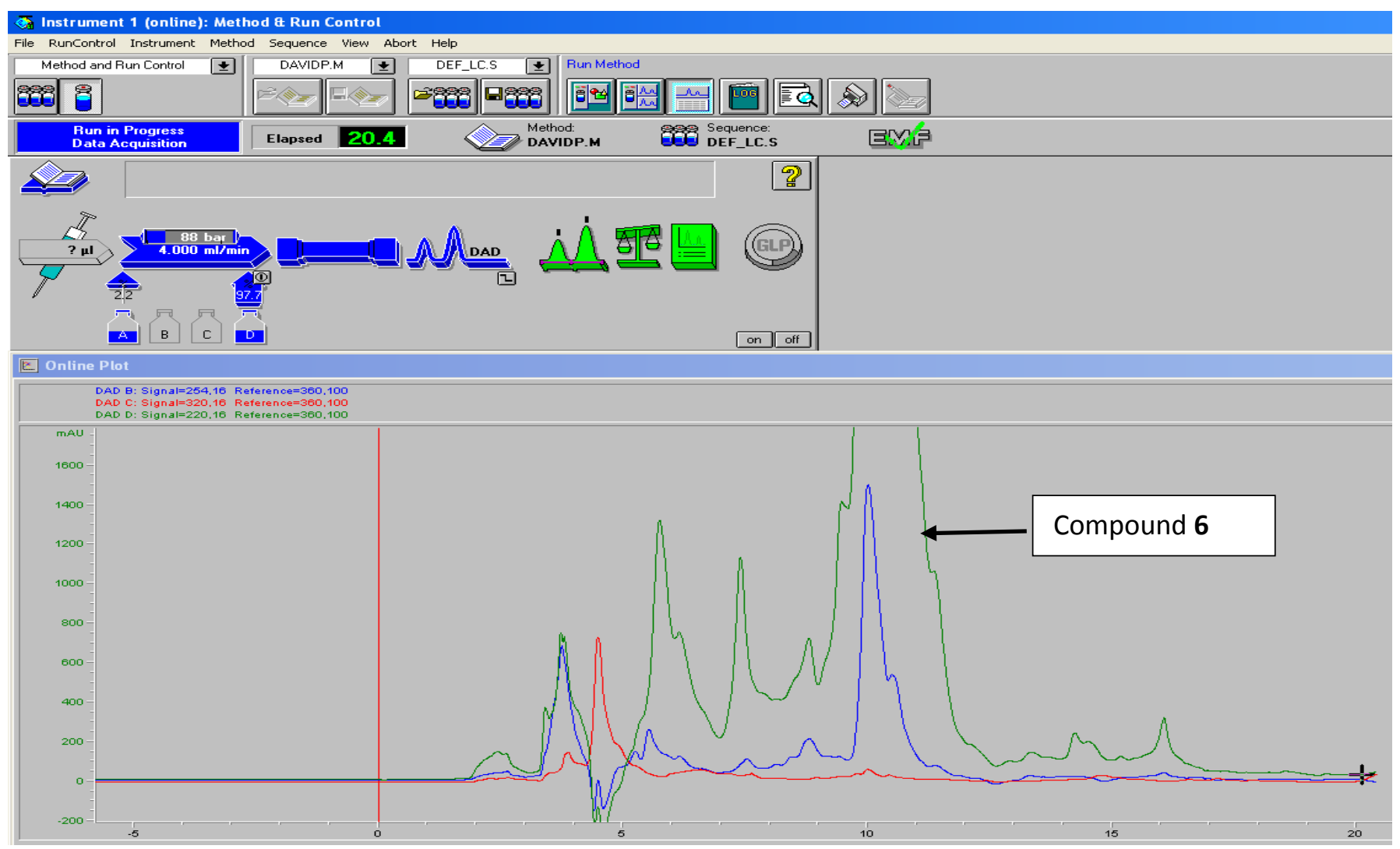




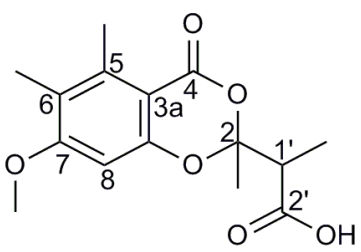

ESI-MS mass spectrum $(\mathrm{m} / \mathrm{z})$ data for compound 7

\section{Nat_NB330-F6-8}

Nat_NB330-F6-8 255 (8.571)

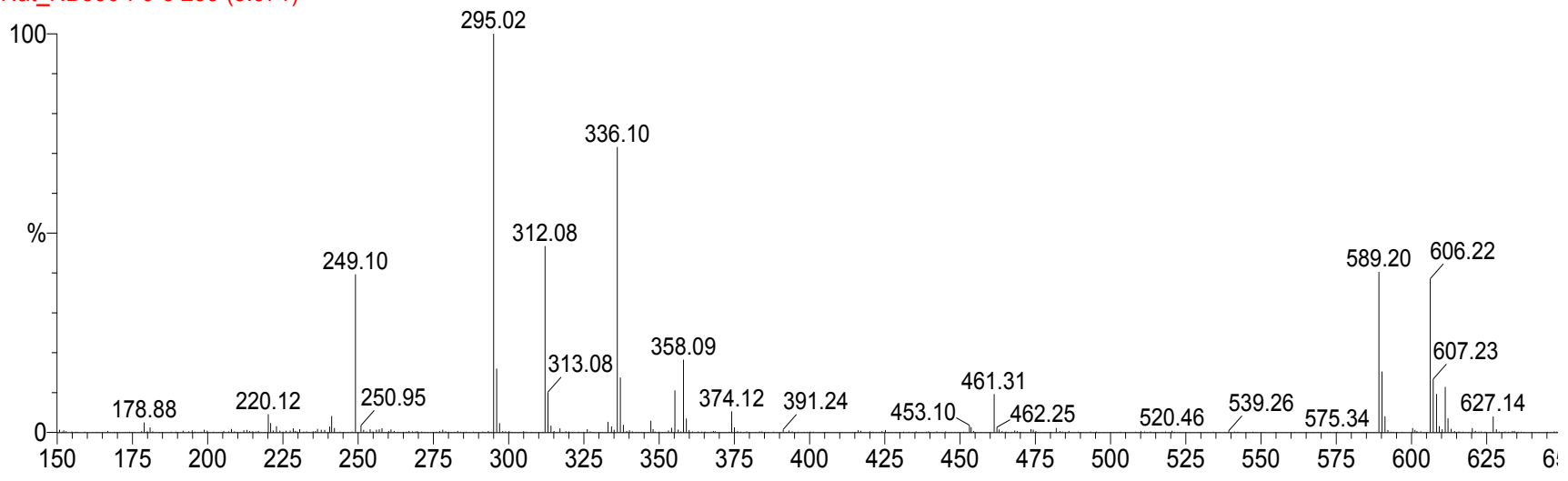

${ }^{1} \mathrm{H}$ NMR spectrum of compound $7\left(400 \mathrm{MHz}, \mathrm{CD}_{3} \mathrm{OD}\right)$

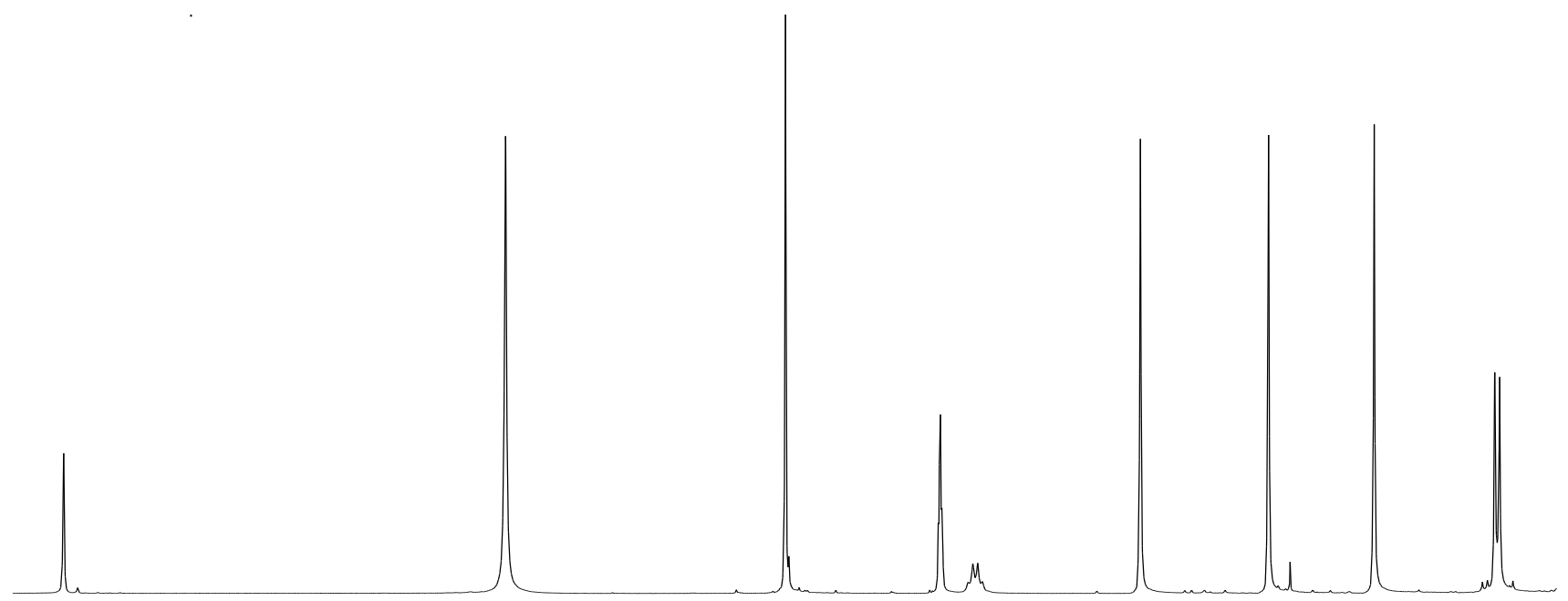

$\begin{array}{llllllllllllllllllllllllllllllllllll}6.6 & 6.4 & 6.2 & 6.0 & 5.8 & 5.6 & 5.4 & 5.2 & 5.0 & 4.8 & 4.6 & 4.4 & 4.2 & 4.0 & 3.8 & 3.6 & 3.4 & 3.2 & 3.0 & 2.8 & 2.6 & 2.4 & 2.2 & 2.0 & 1.8 & 1.6 & 1.4 & 1.2\end{array}$ 
${ }^{13} \mathrm{C}$ NMR spectrum of compound $7\left(100 \mathrm{MHz}, \mathrm{CD}_{3} \mathrm{OD}\right)$

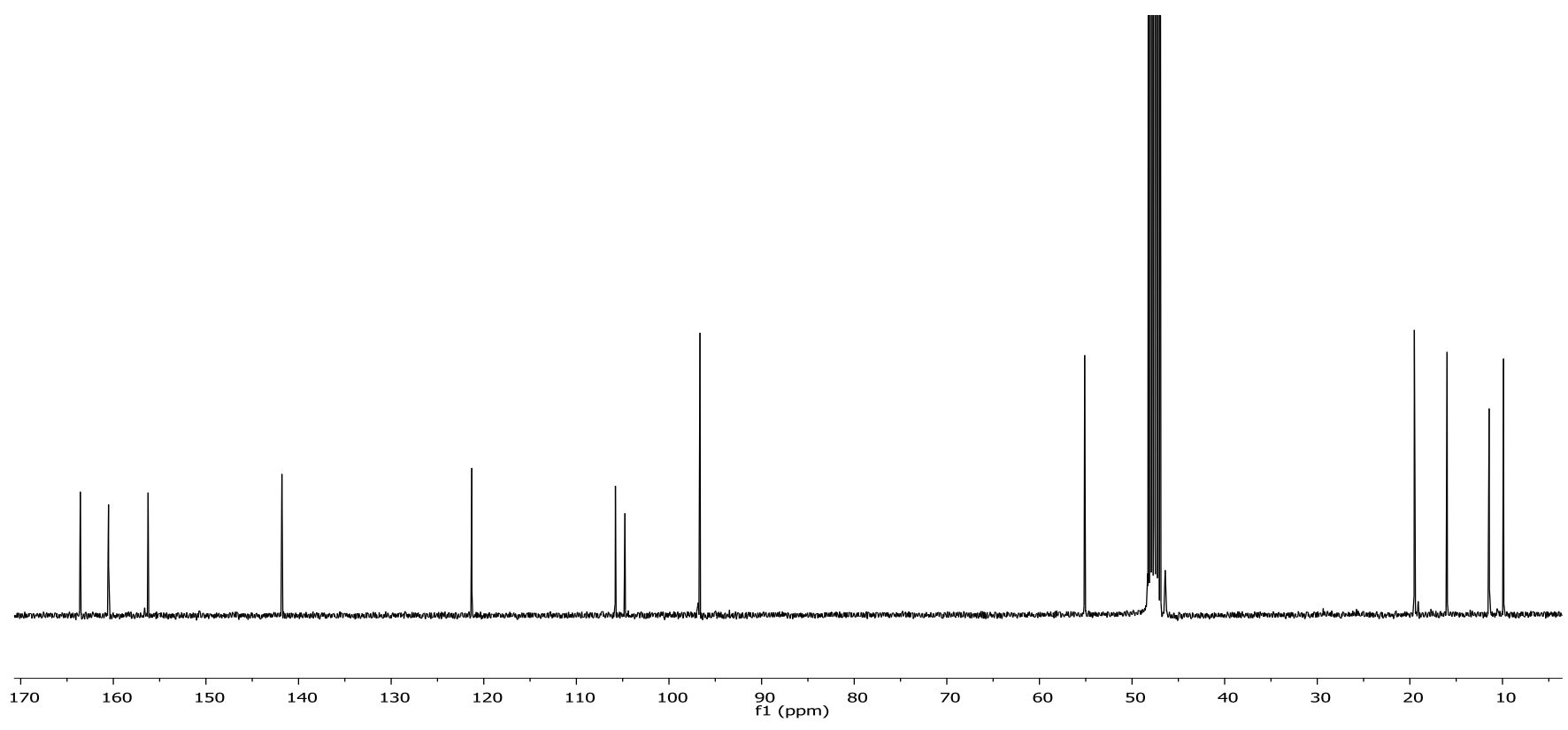

HPLC chromatogram of compound 7.

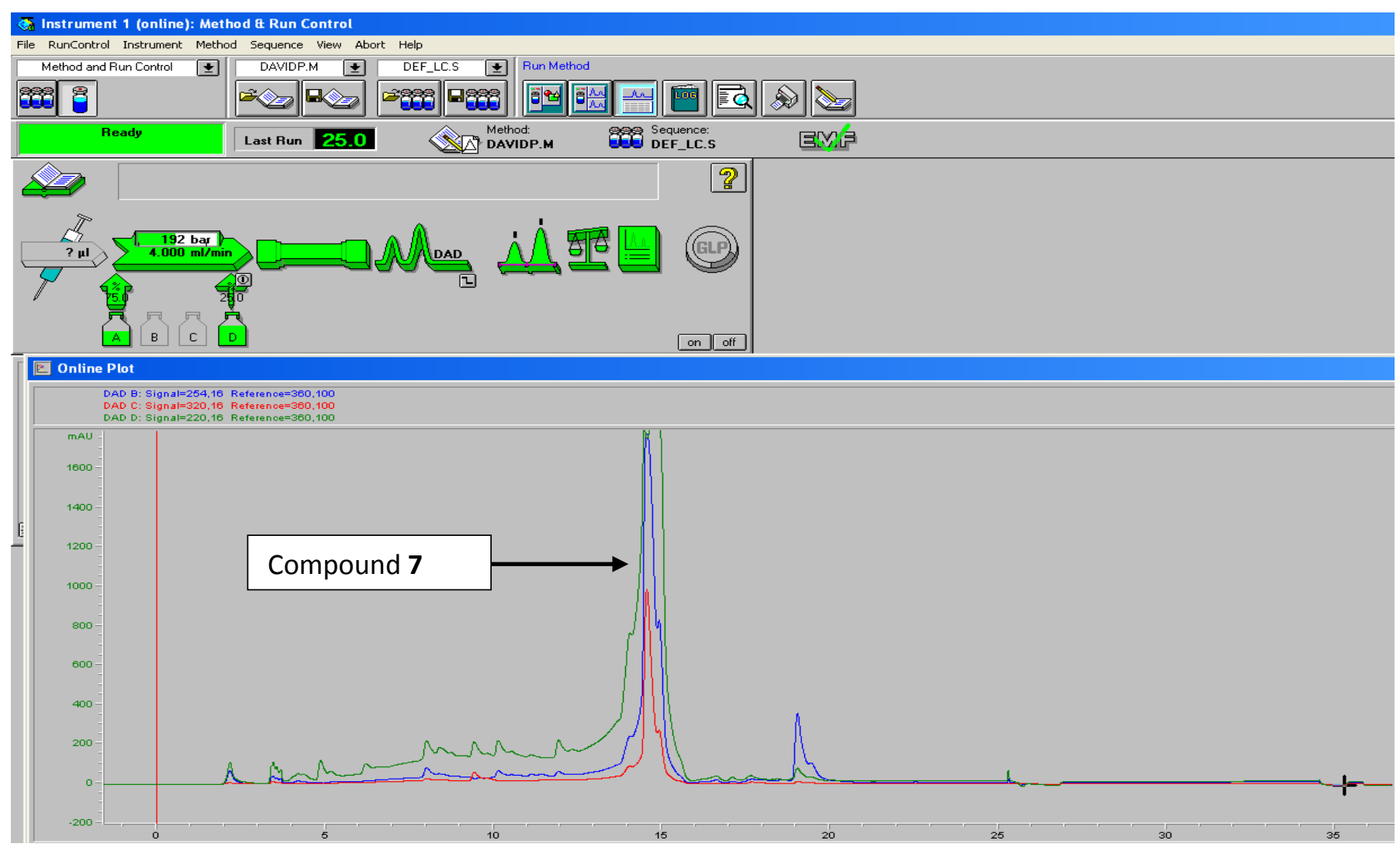


<smiles>COc1cc(O[14C](C)=C(C)C(=O)O)c(C(=O)O)c(C)c1C</smiles>

ESI-MS mass spectrum $(\mathrm{m} / \mathrm{z})$ data for compound $\mathbf{8}$

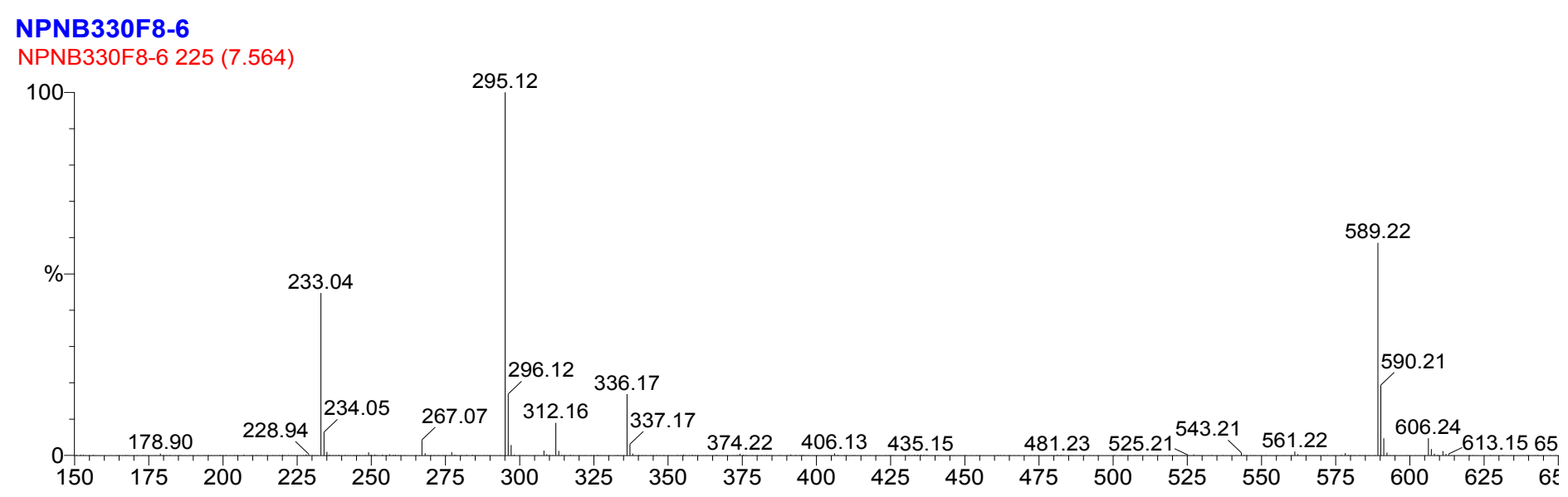

${ }^{1} \mathrm{H}$ NMR spectrum of compound $8\left(400 \mathrm{MHz}, \mathrm{CD}_{3} \mathrm{OD}\right)$

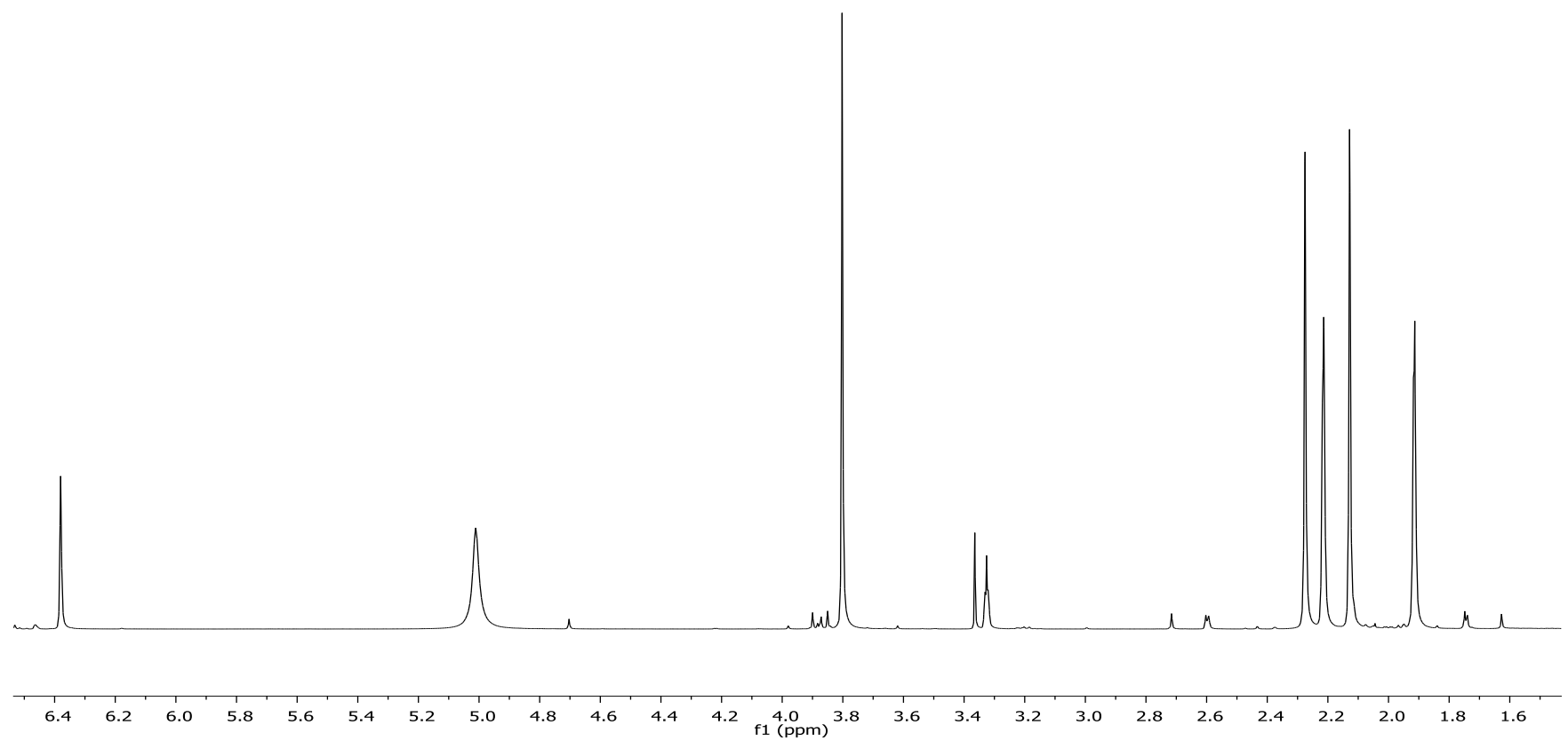


${ }^{13} \mathrm{C}$ NMR spectrum of compound $8\left(100 \mathrm{MHz}, \mathrm{CD}_{3} \mathrm{OD}\right)$

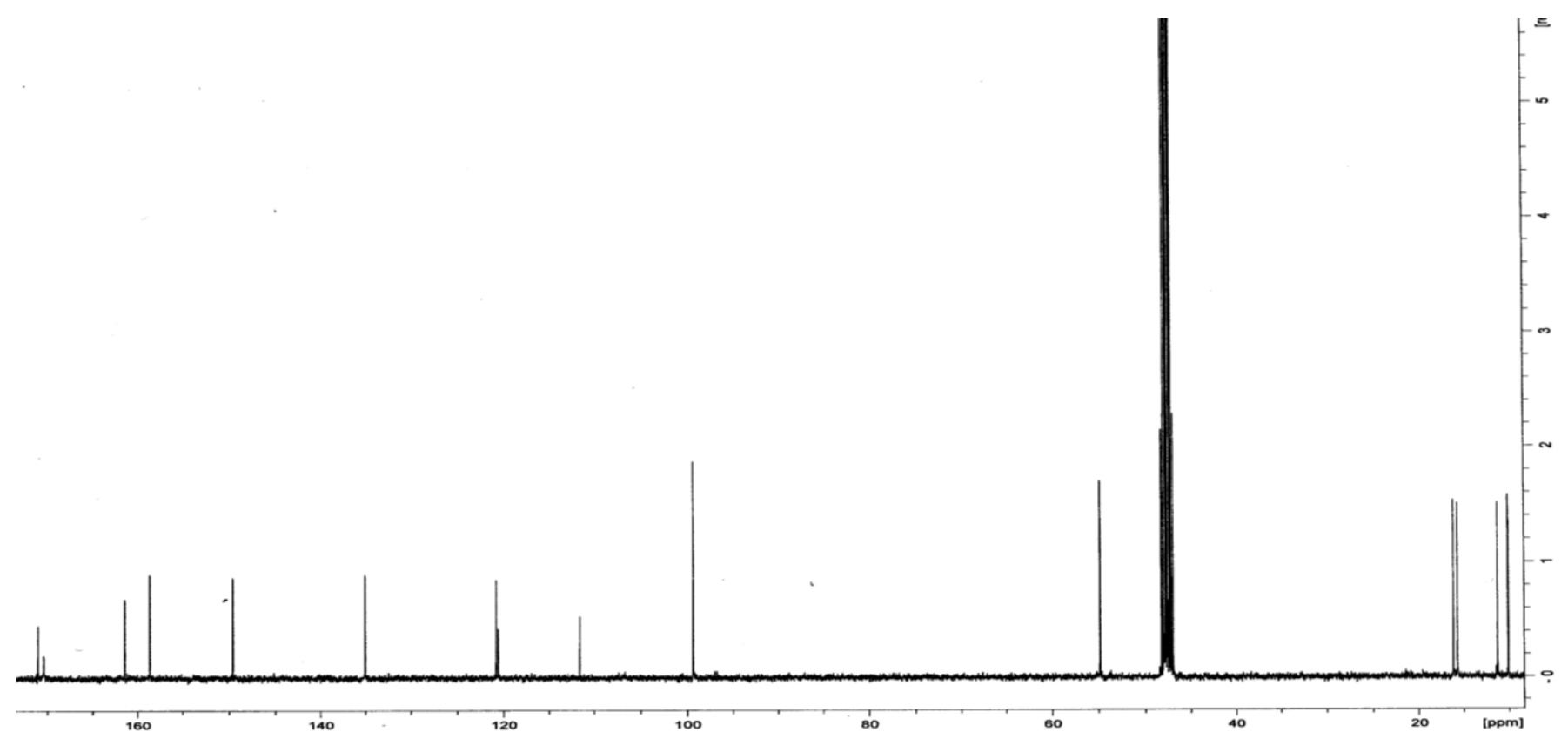

HPLC chromatogram of compound $\mathbf{8}$.

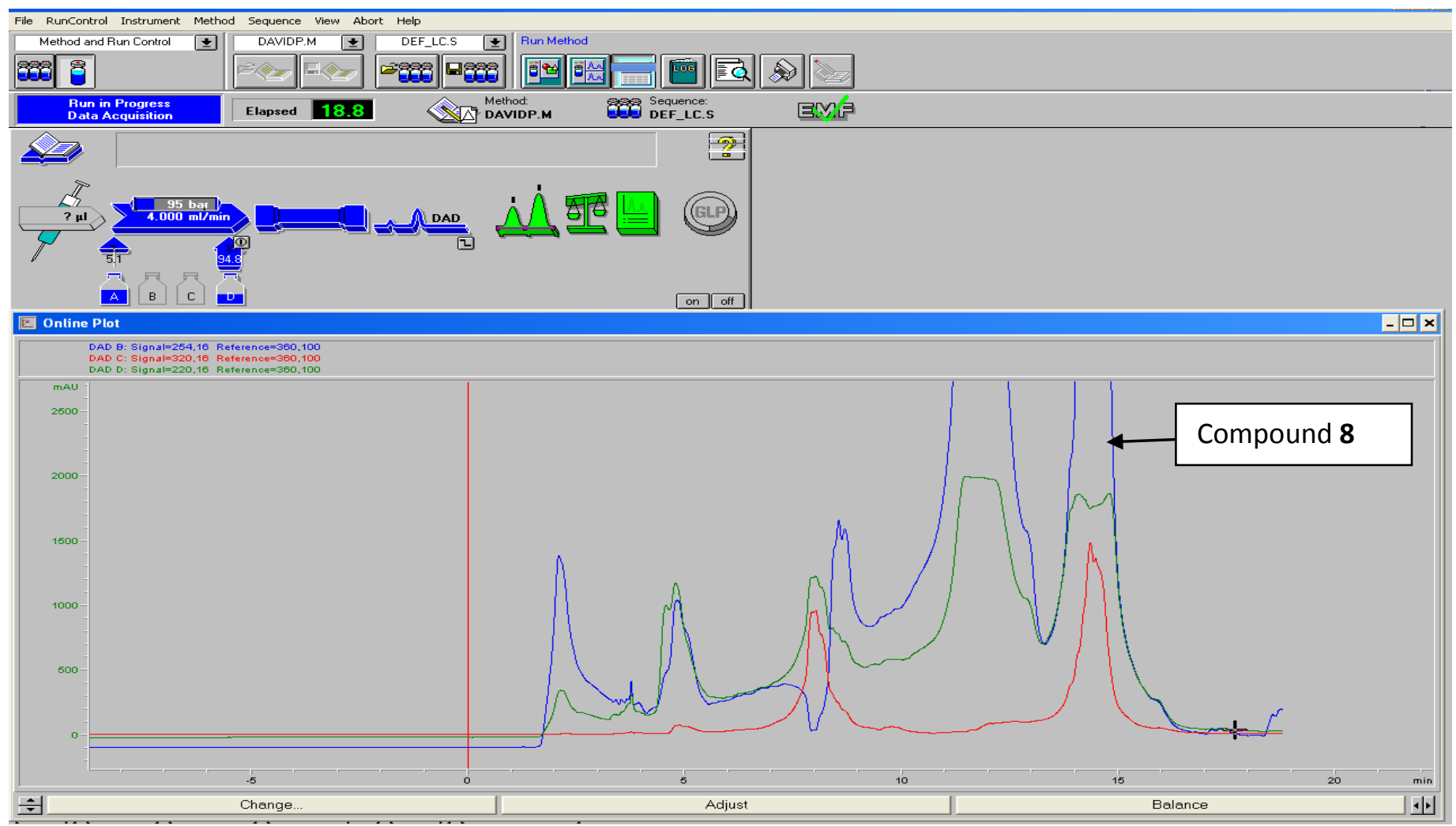




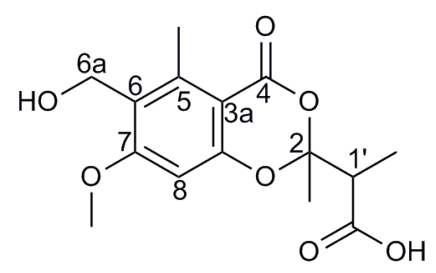

ESI-MS mass spectrum $(\mathrm{m} / \mathrm{z})$ data for compound 9

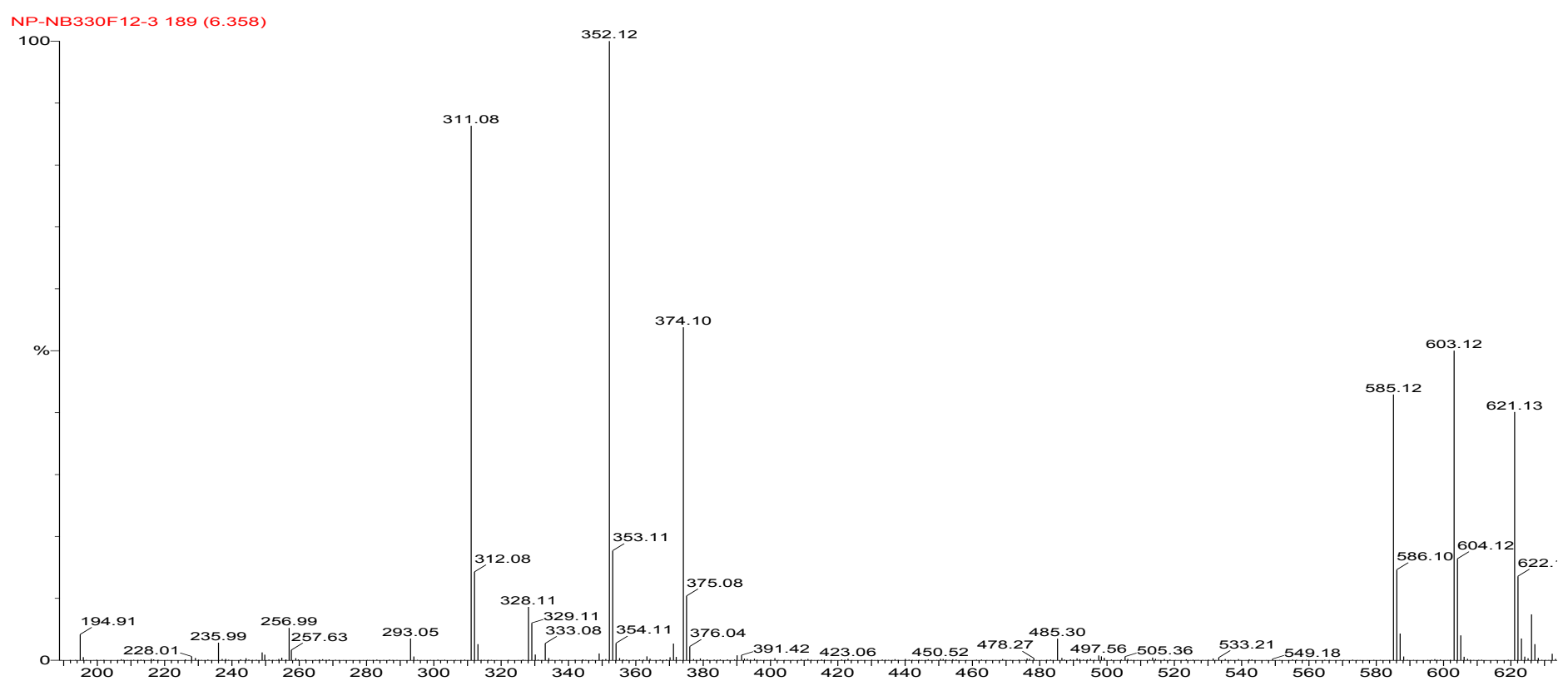

${ }^{1} \mathrm{H}$ NMR spectrum of compound $9\left(400 \mathrm{MHz}, \mathrm{CD}_{3} \mathrm{OD}\right)$

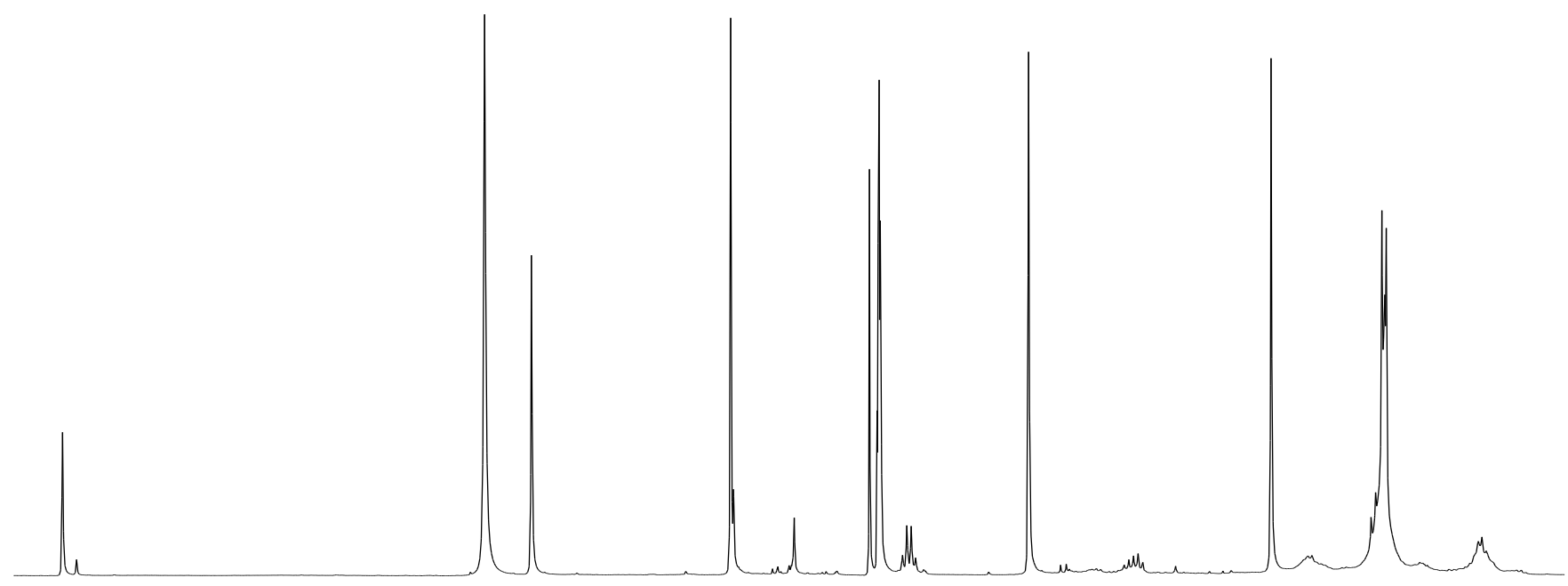

$\begin{array}{lllllllllllllllllllllllllllllll}6.6 & 6.4 & 6.2 & 6.0 & 5.8 & 5.6 & 5.4 & 5.2 & 5.0 & 4.8 & 4.6 & 4.4 & 4.2 & 4.0 & 3.8 & 3.6 & 3.4 & 3.2 & 3.0 & 2.8 & 2.6 & 2.4 & 2.2 & 2.0 & 1.8 & 1.6 & 1.4 & 1.2 & 1.0 & 0.8 & 0.6\end{array}$ 
${ }^{13} \mathrm{C}$ NMR spectrum of compound $9\left(100 \mathrm{MHz}, \mathrm{CD}_{3} \mathrm{OD}\right)$
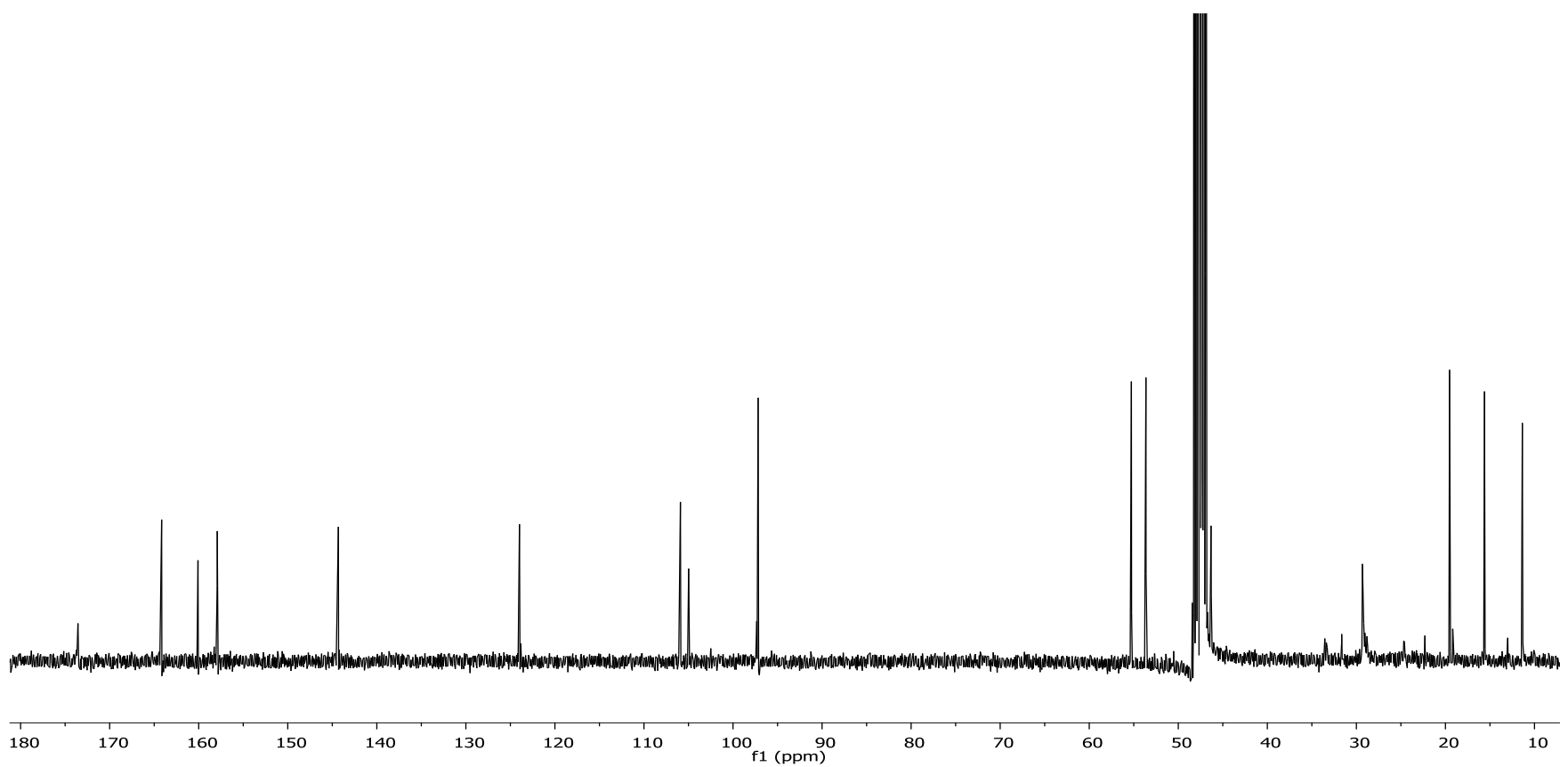

HPLC chromatogram of compound 9.

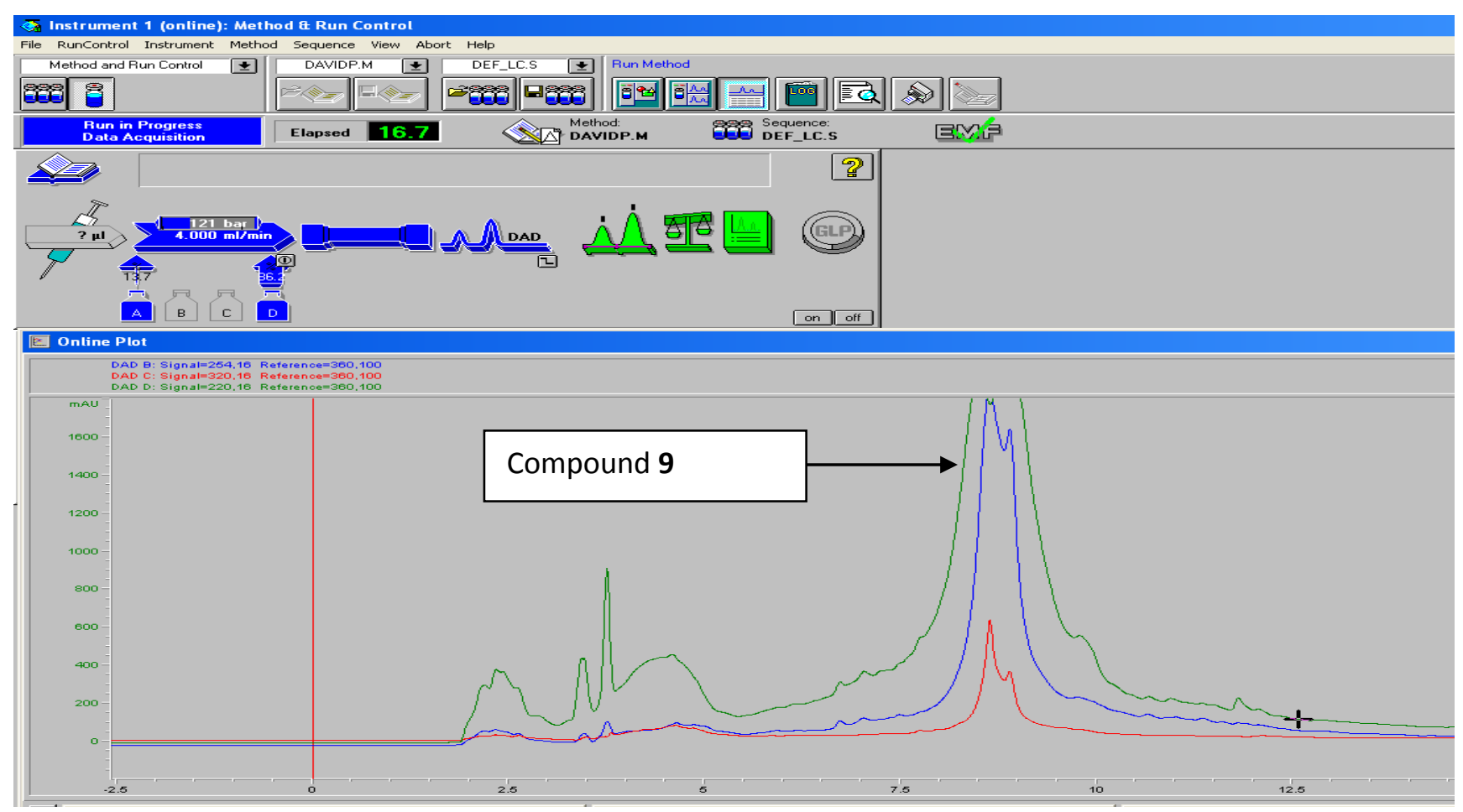




\section{C: Bioassay graphs for compounds 1-9}

\section{Compound 1}

Antimicrobial activity against $M$. violaceum (a), S. cerevisiae (b), B. subtilis (c) and E. coli (d).
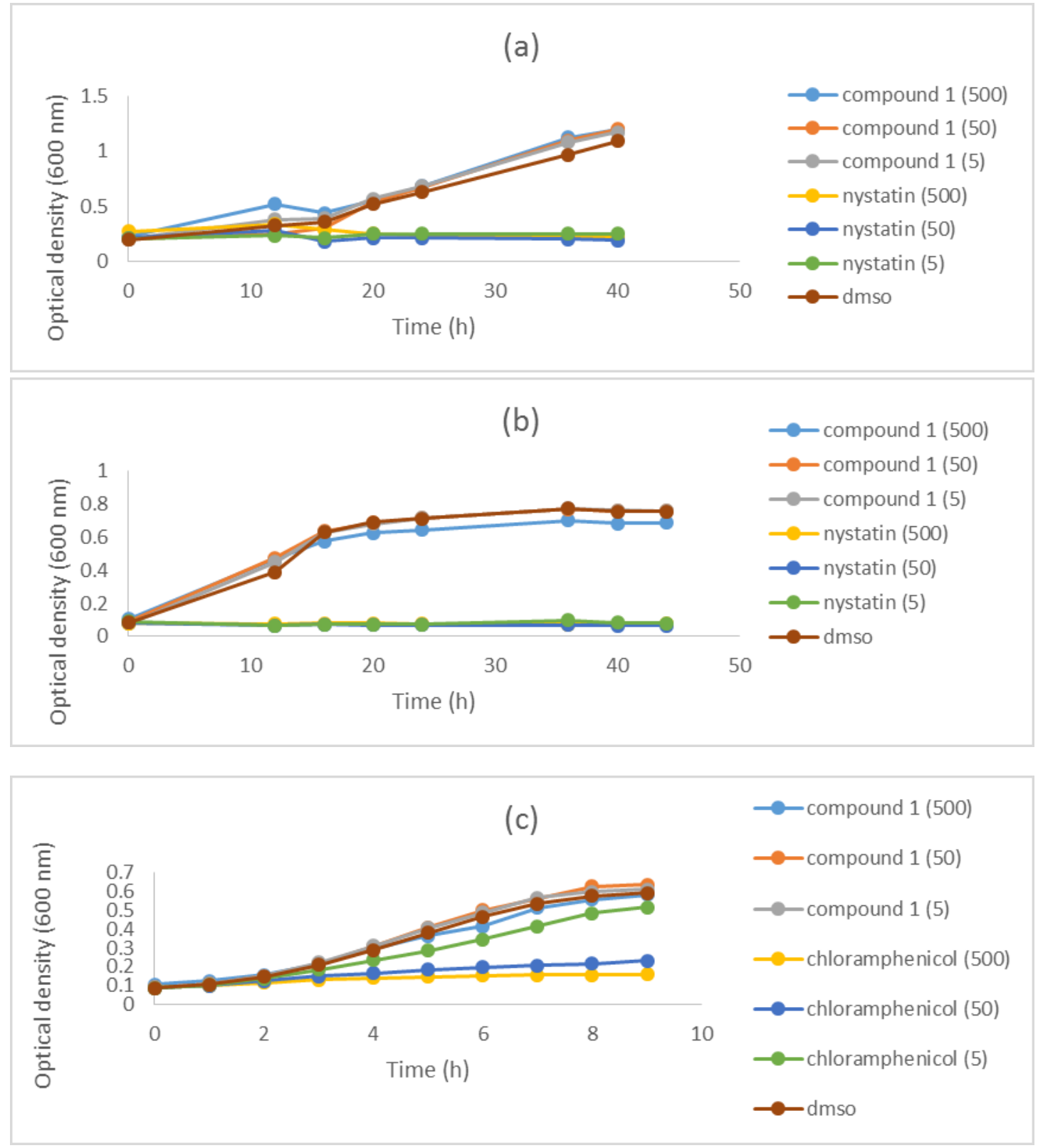


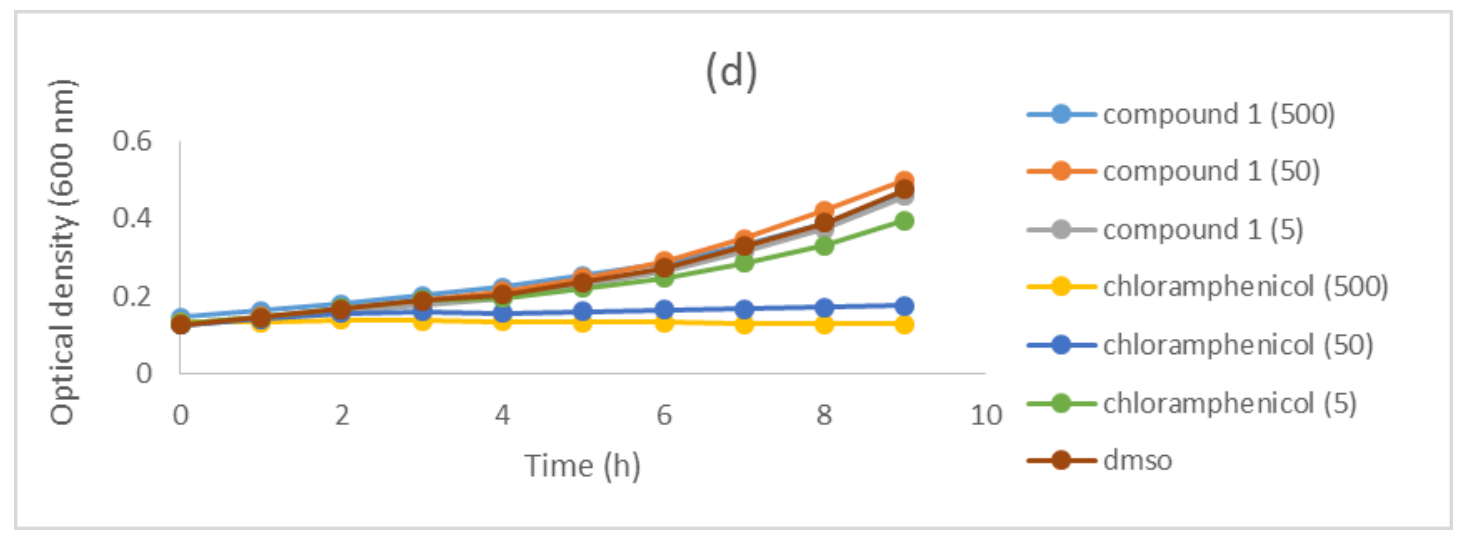

\section{Compound 2}

Antimicrobial activity against $M$. violaceum (a), S. cerevisiae (b), B. subtilis (c) and E. coli (d).

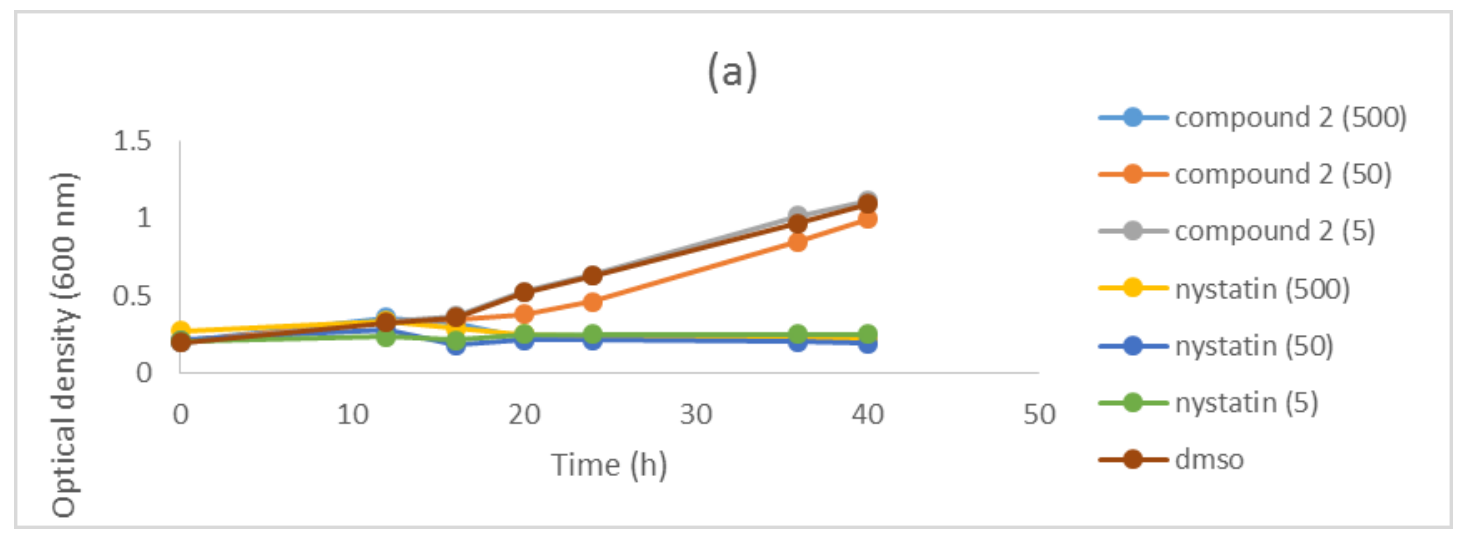



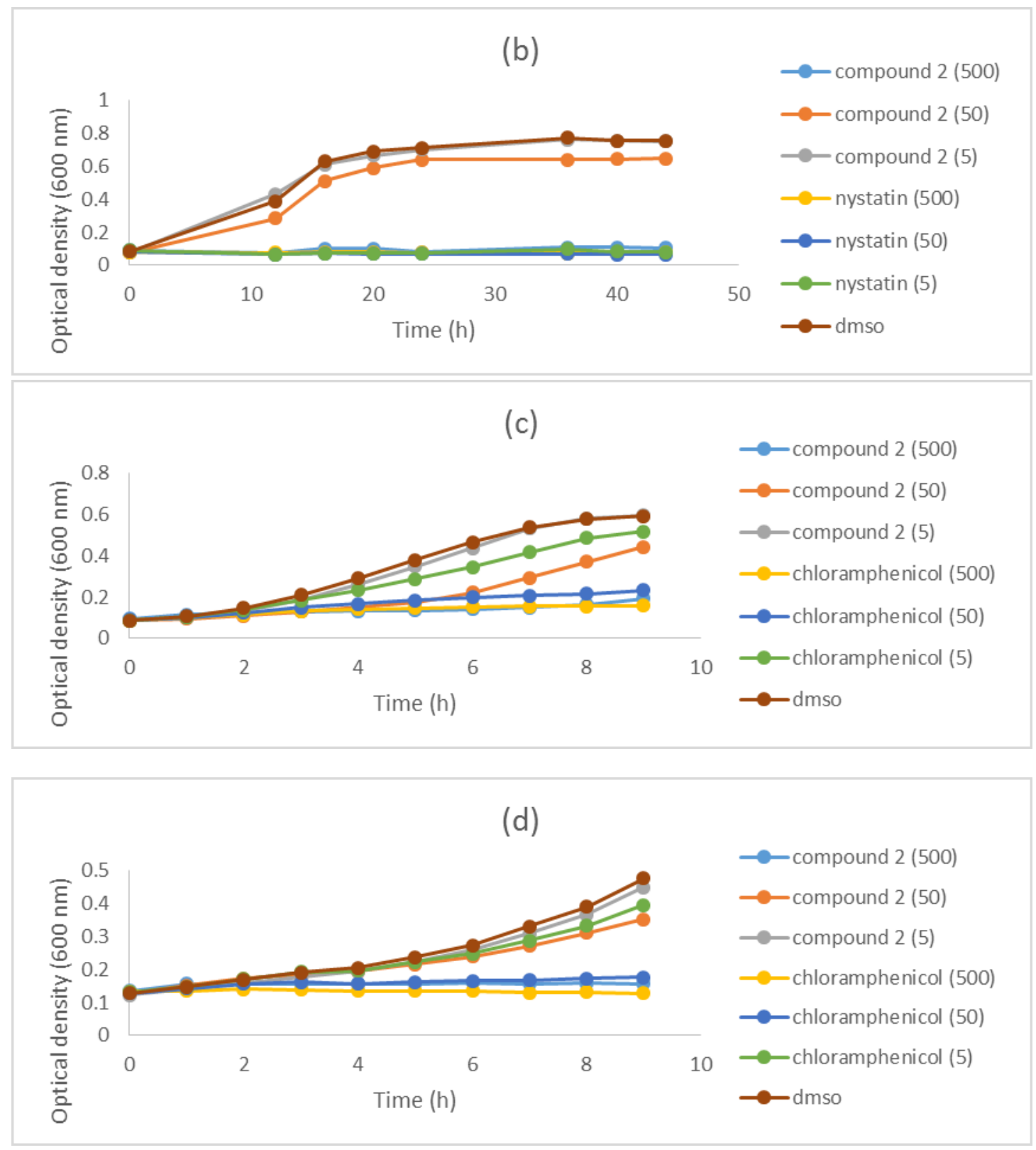


\section{Compound 3}

Antimicrobial activity against $M$. violaceum (a), S. cerevisiae (b), B. subtilis (c) and E. coli (d).

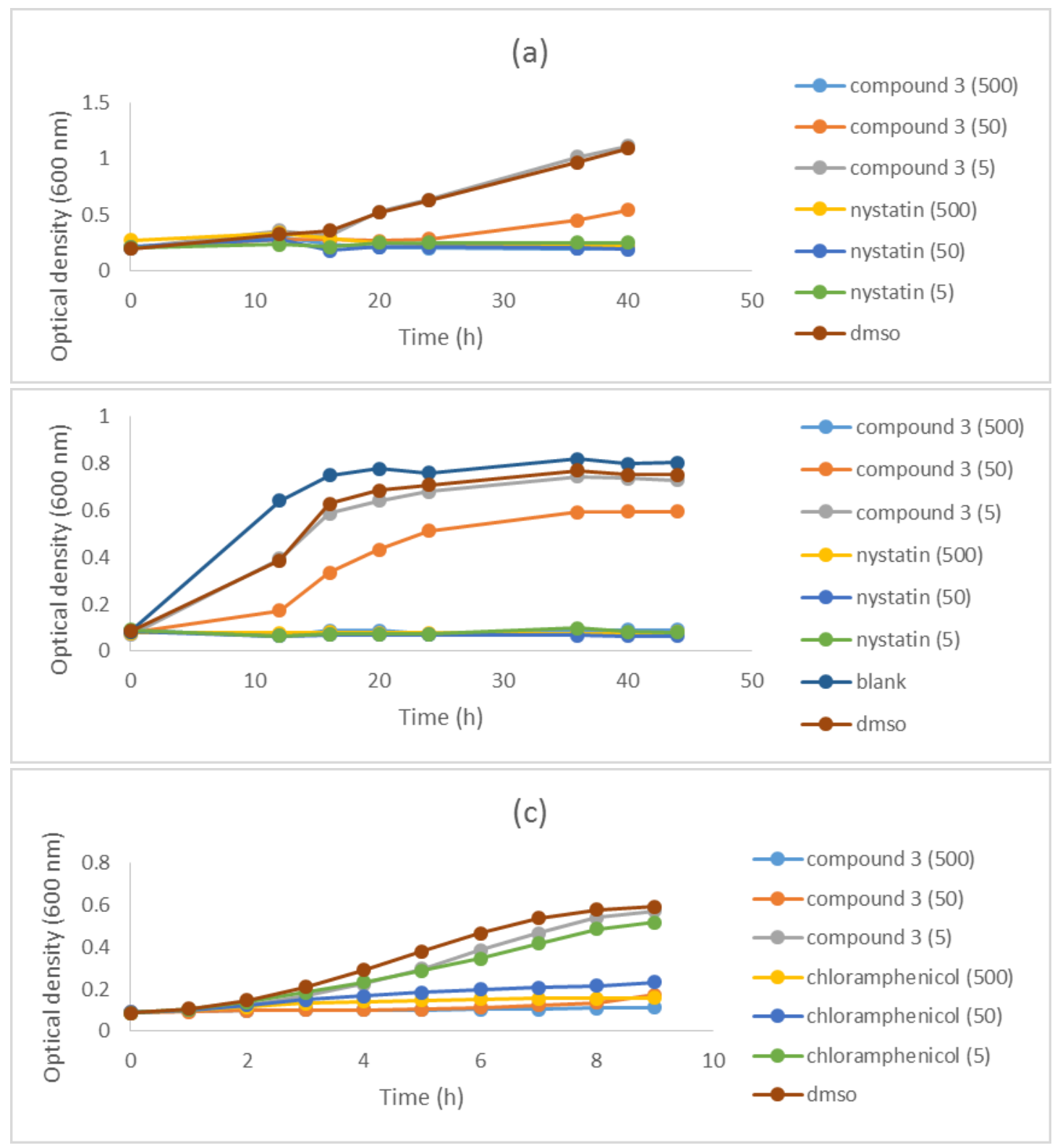




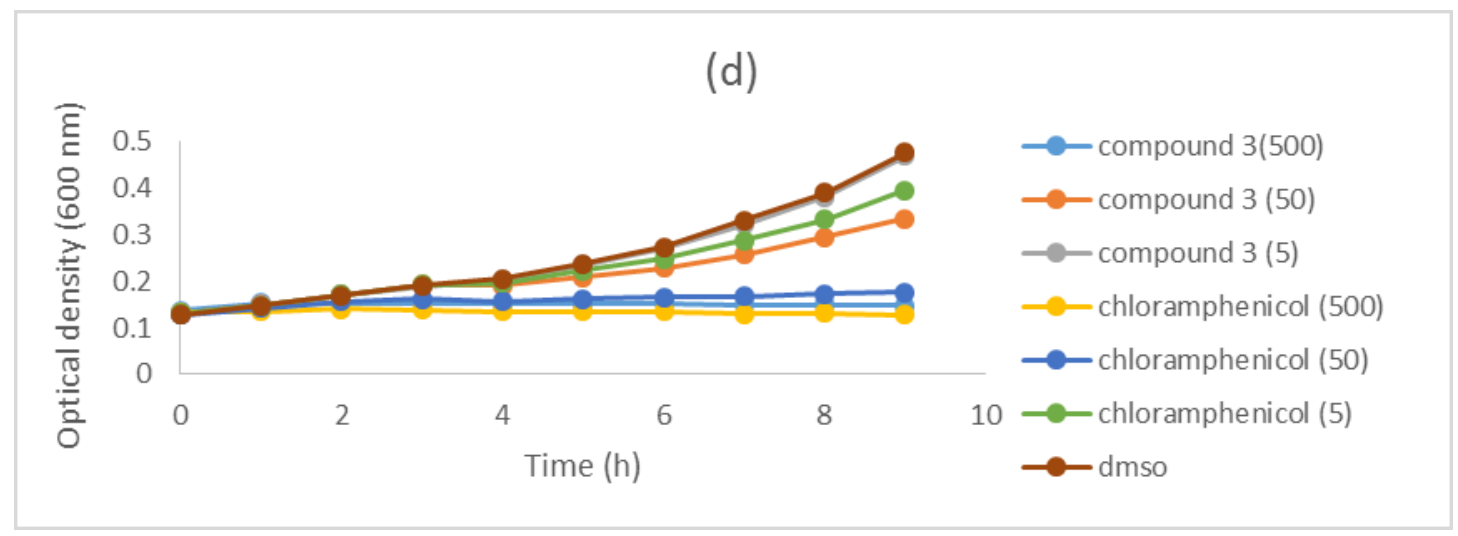

\section{Compound 4}

Antimicrobial activity against $M$. violaceum (a), S. cerevisiae (b), B. subtilis (c) and E. coli (d).

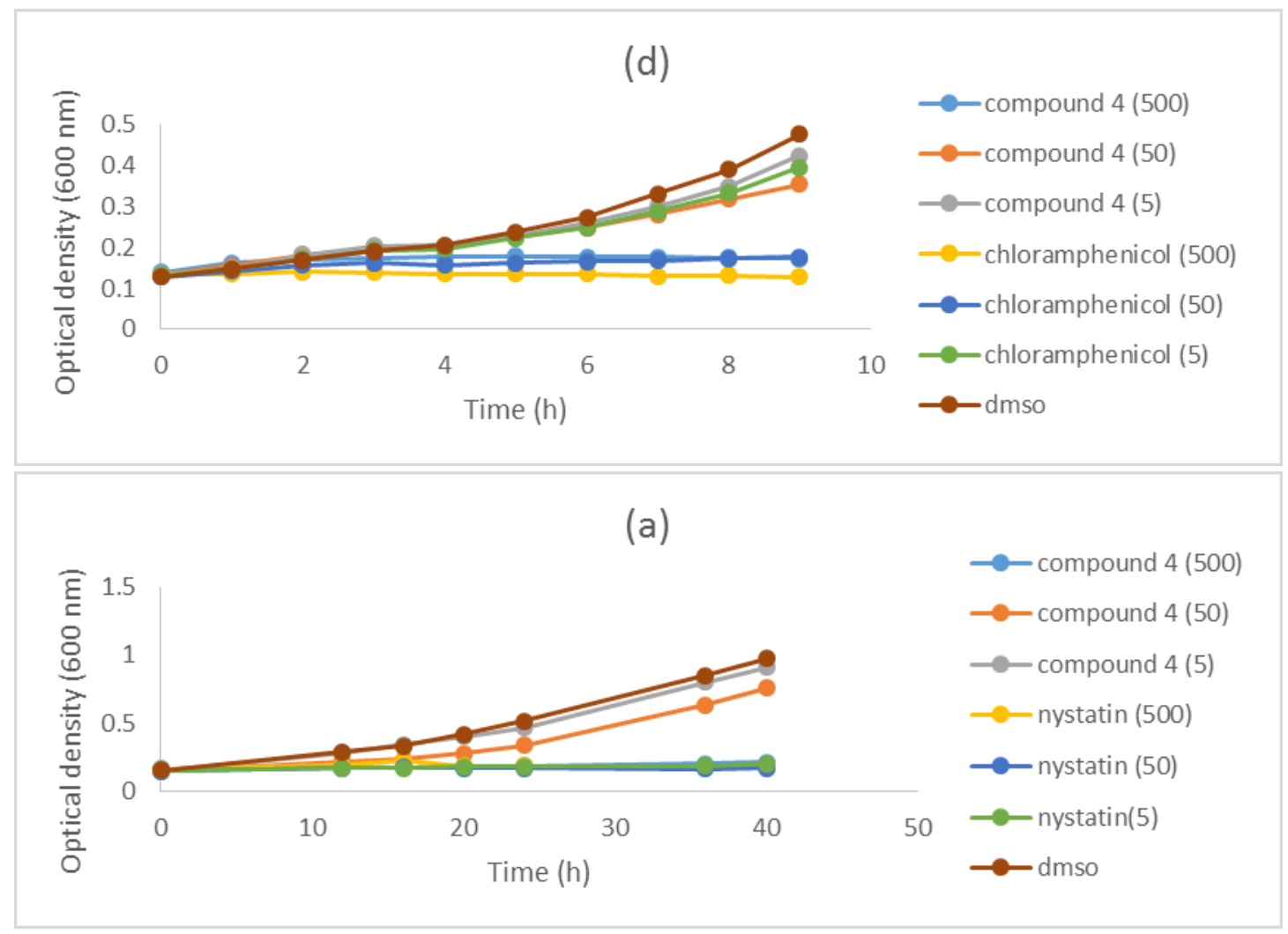



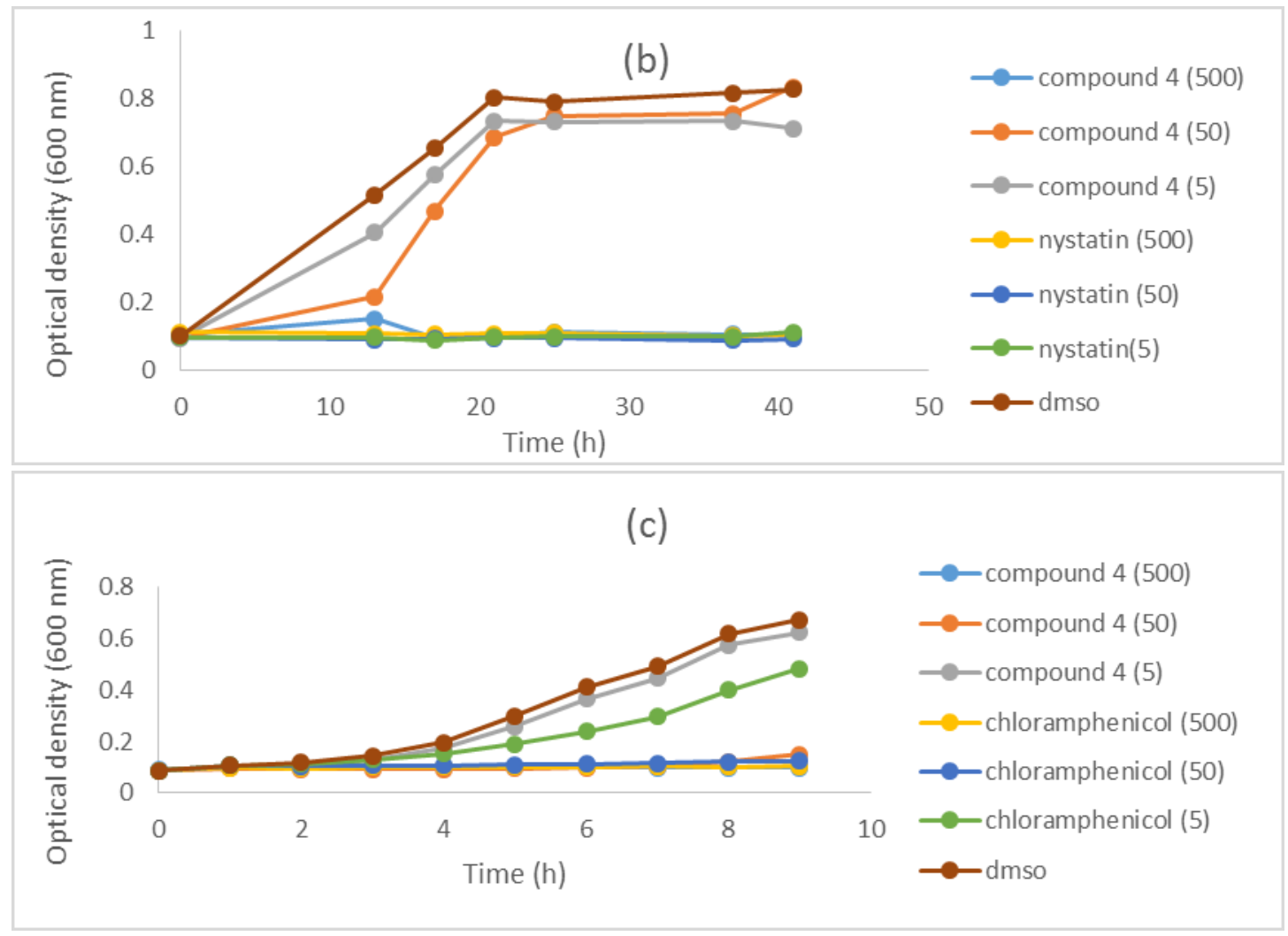

\section{Compound 5}

Antimicrobial activity against M. violaceum (a), S. cerevisiae (b), B. subtilis (c) and E. coli (d).

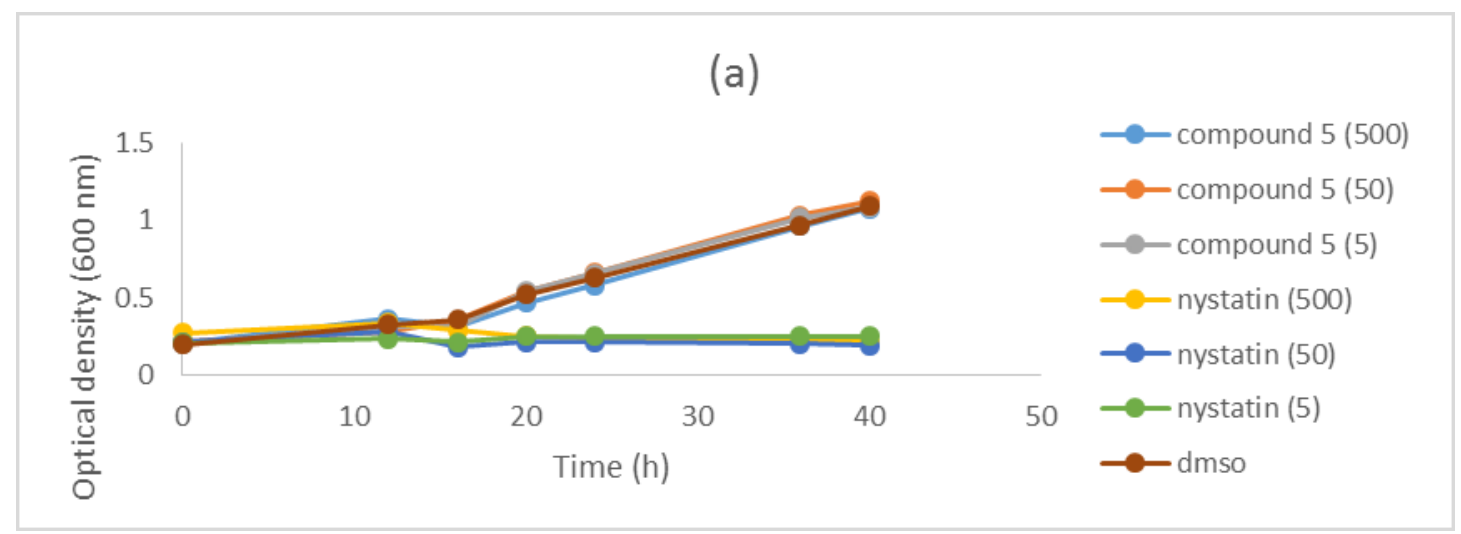



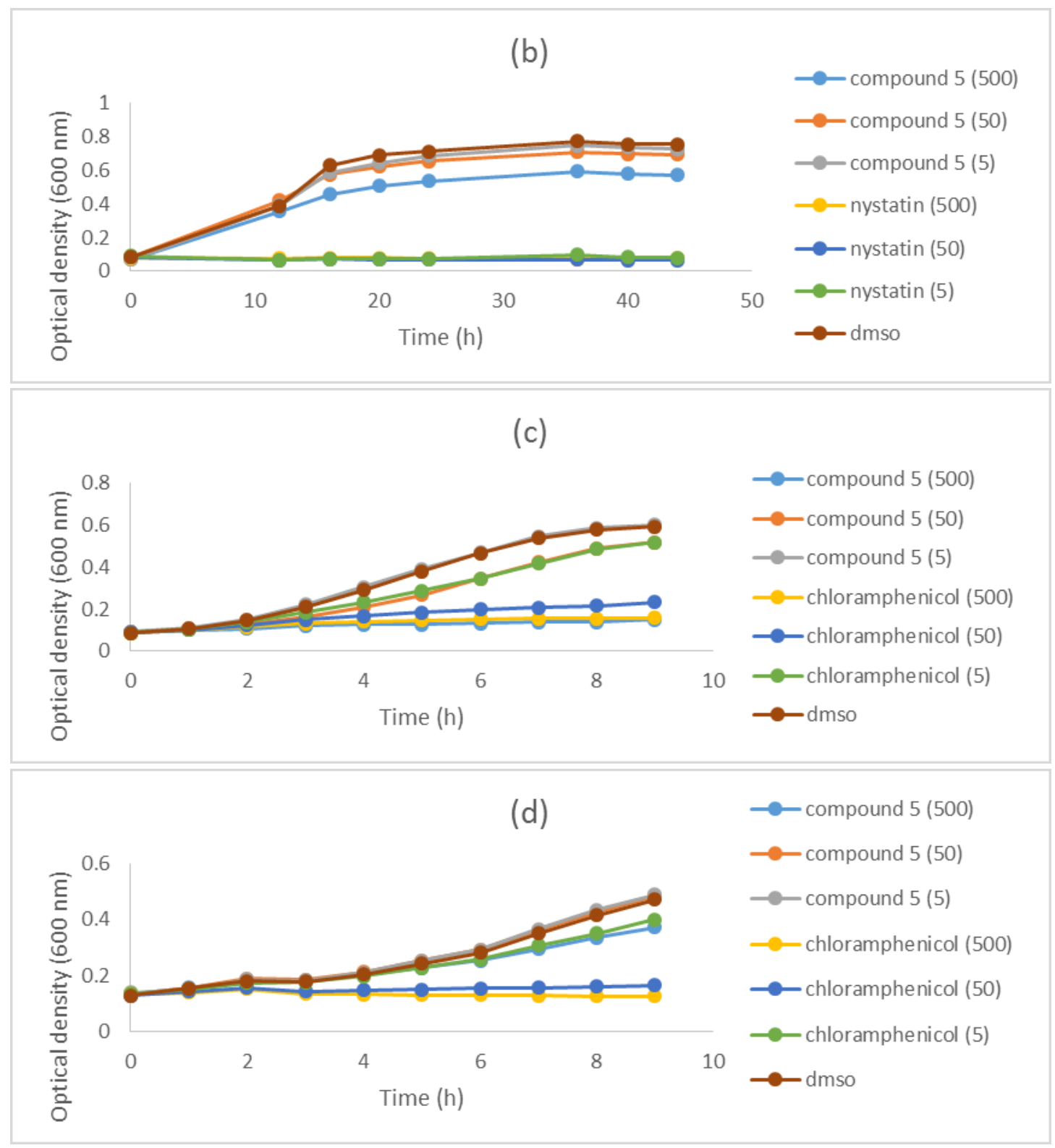


\section{Compound 6}

Antimicrobial activity against $M$. violaceum (a), S. cerevisiae (b), B. subtilis (c) and E. coli (d).

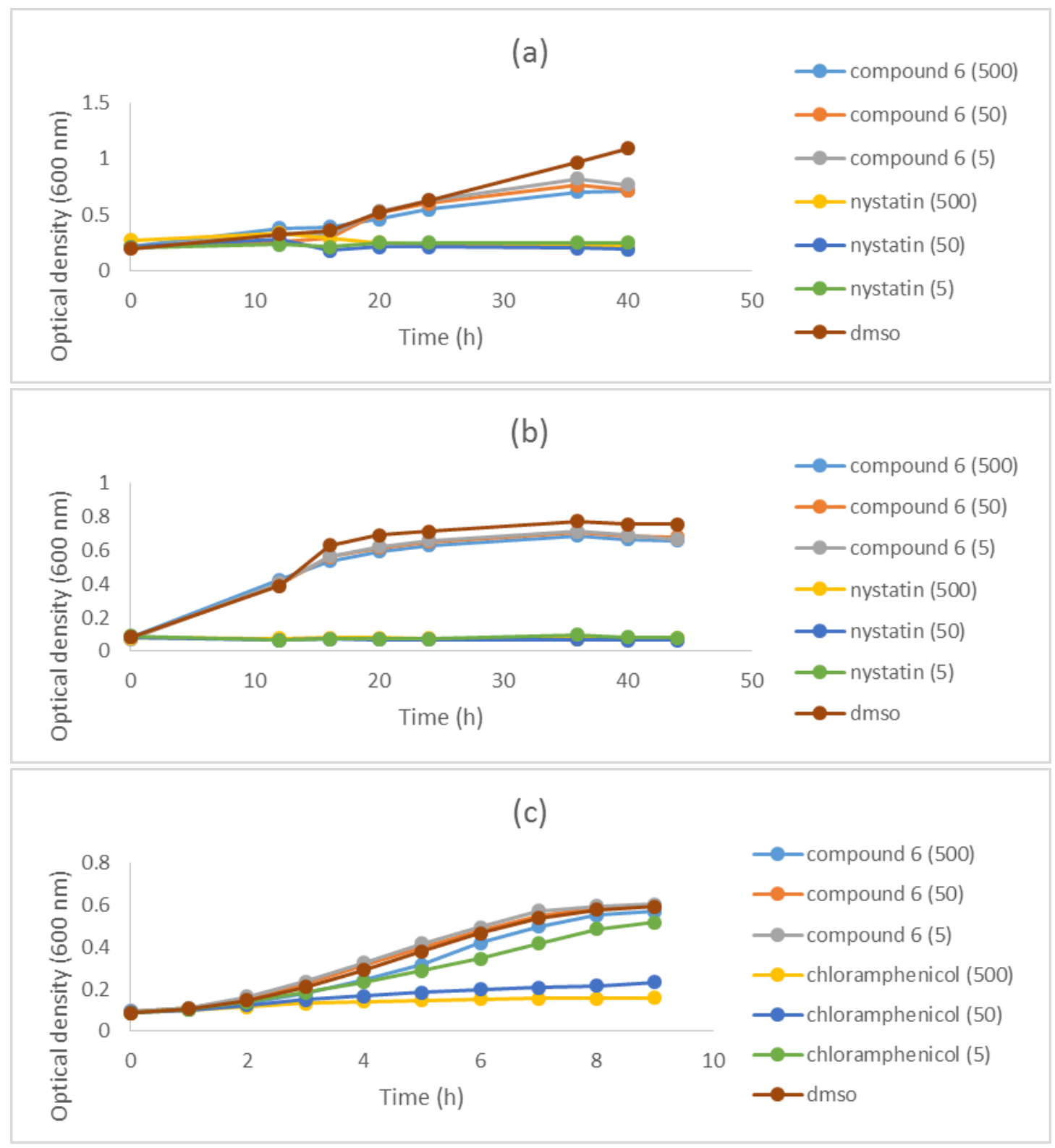




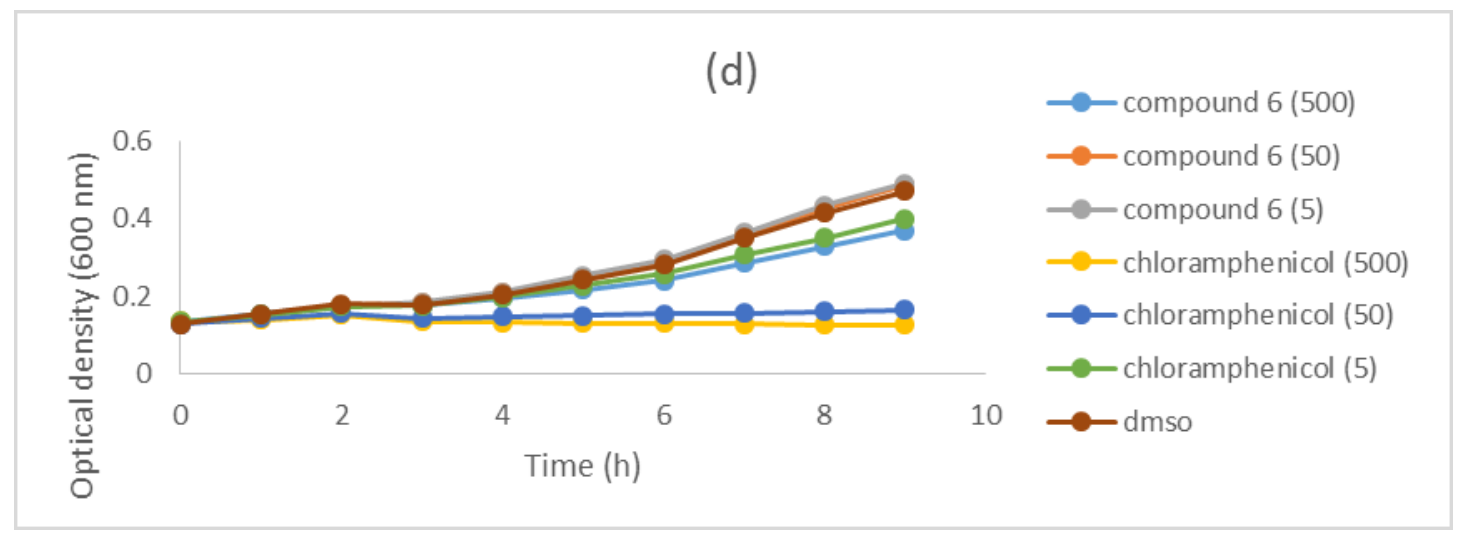

\section{Compound 7}

Antimicrobial activity against $M$. violaceum (a), S. cerevisiae (b), B. subtilis (c) and E. coli (d).
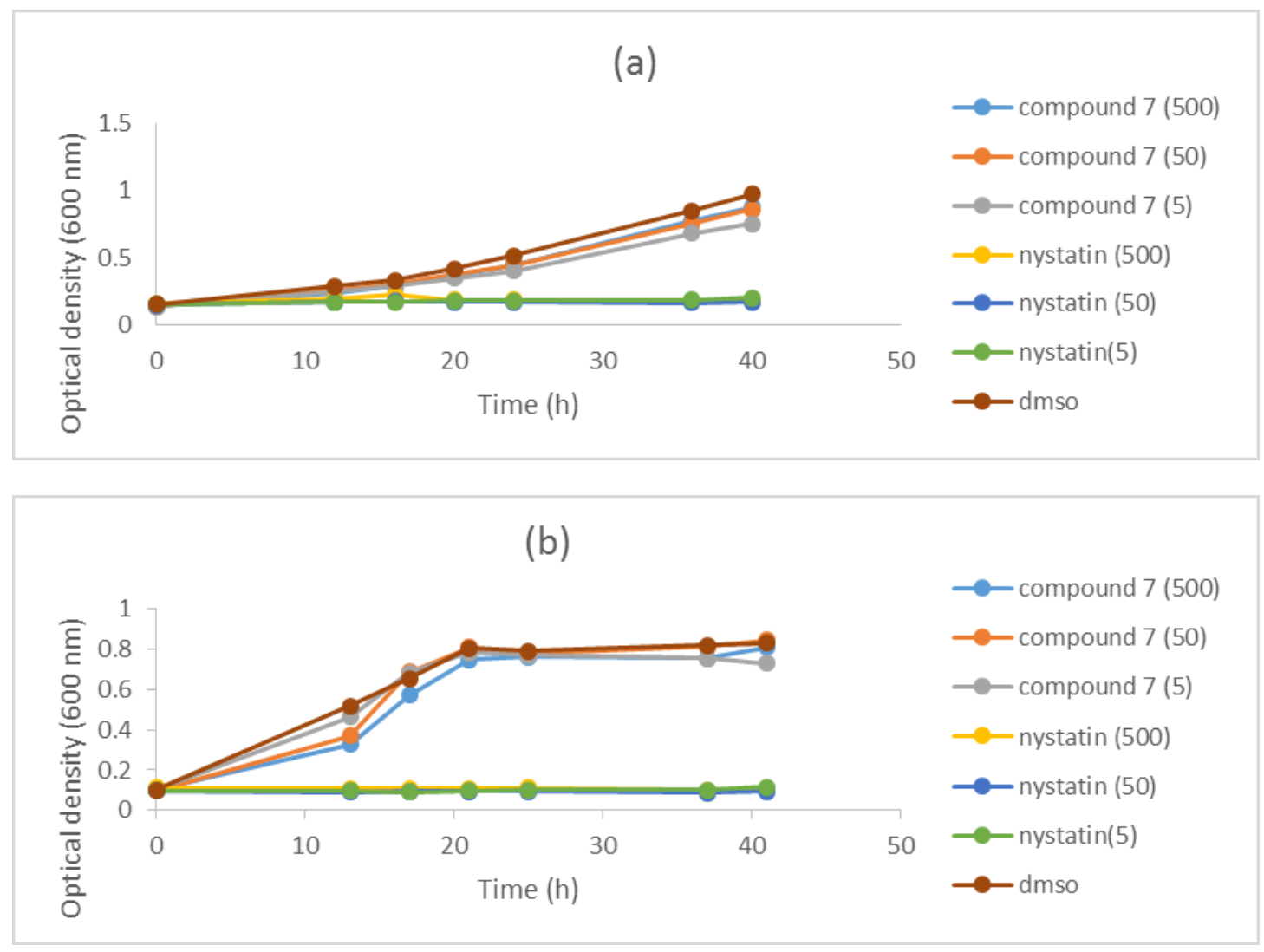

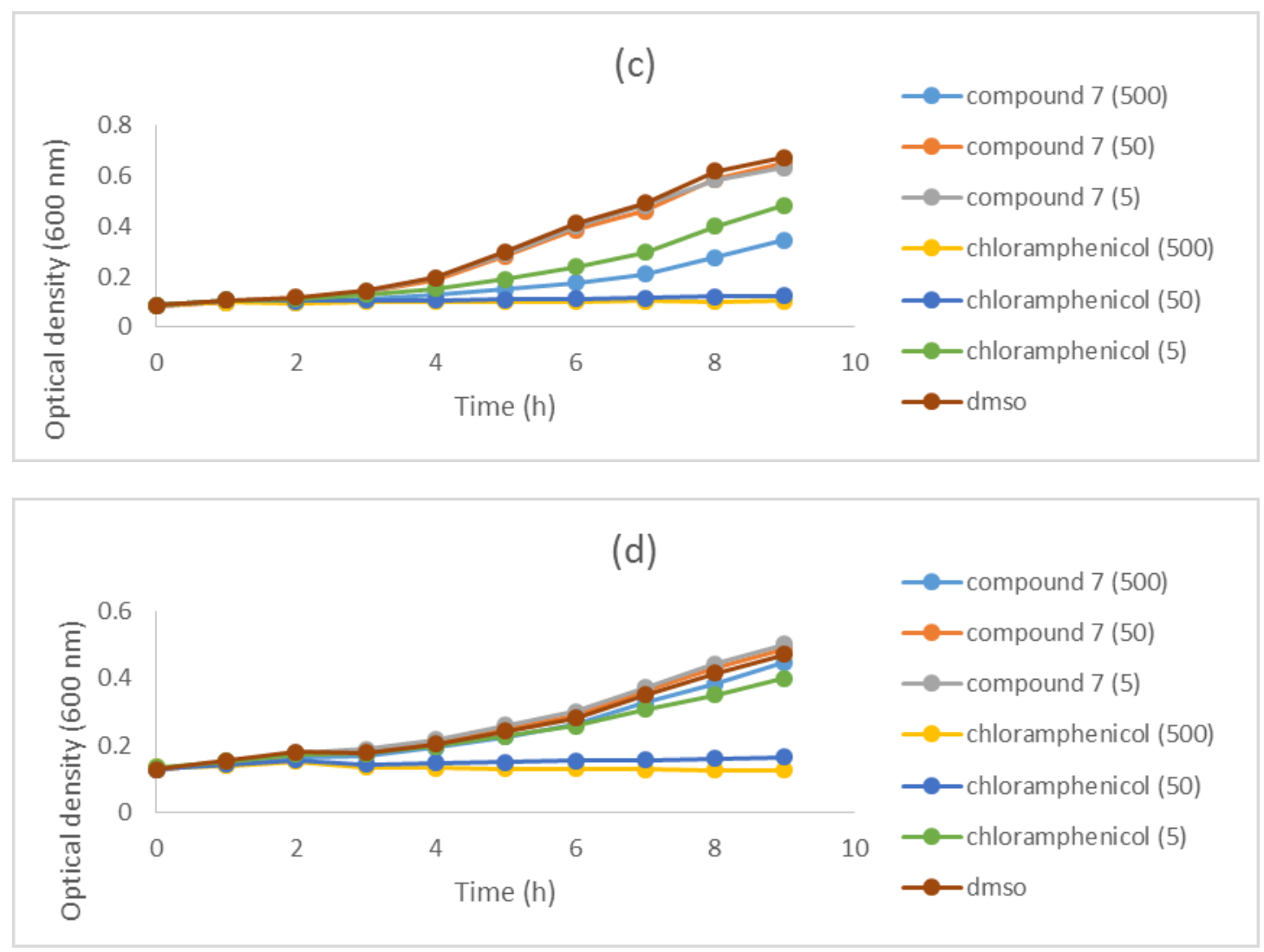

\section{Compound 8}

Antimicrobial activity against $M$. violaceum (a), S. cerevisiae (b), B. subtilis (c) and E. coli (d).

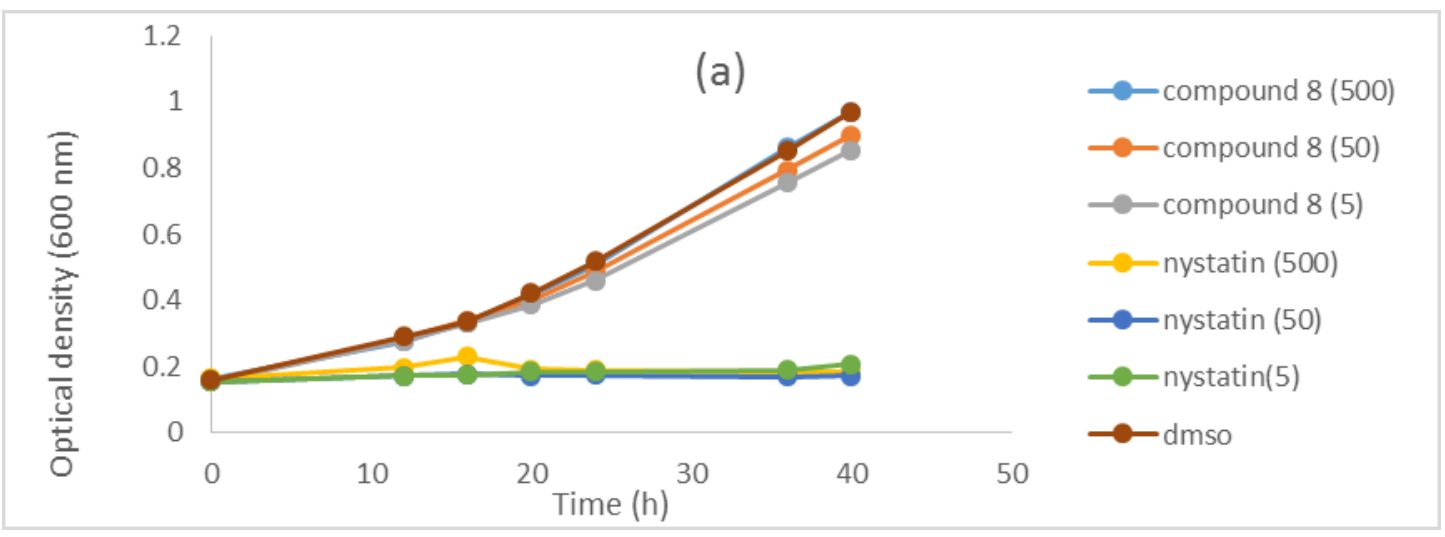



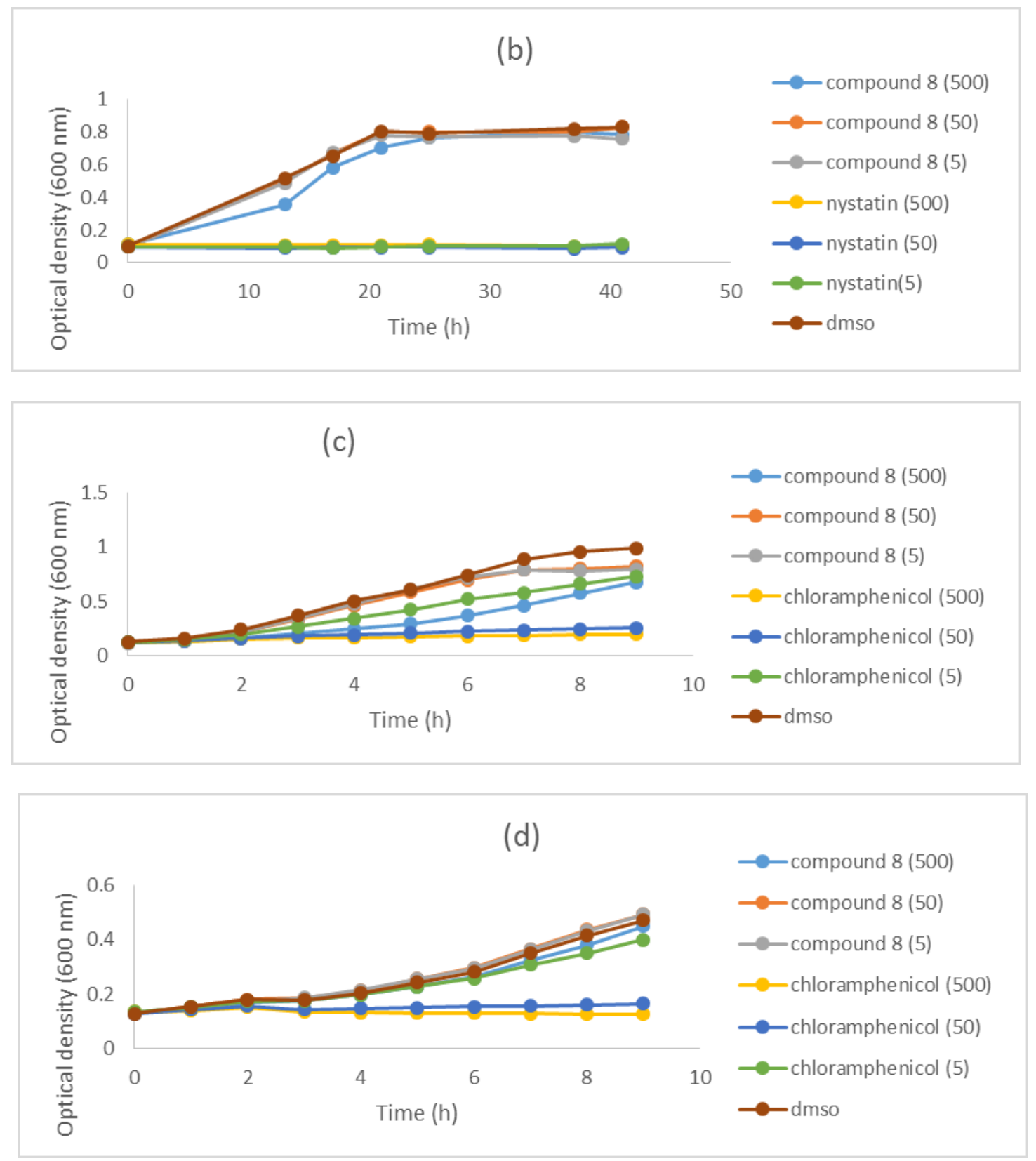


\section{Compound 9}

Antimicrobial activity against $M$. violaceum (a), S. cerevisiae (b), B. subtilis (c) and E. coli (d).
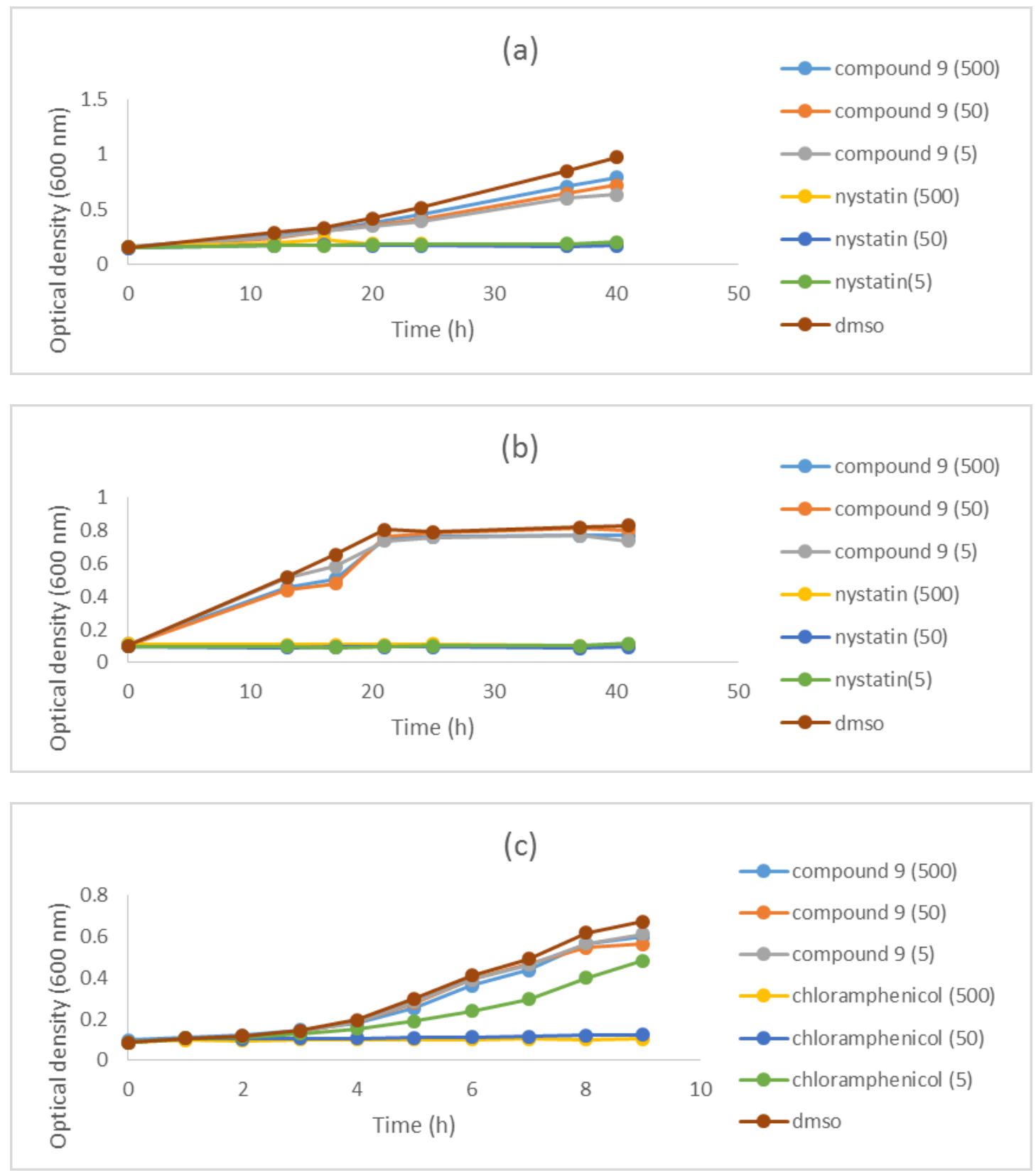


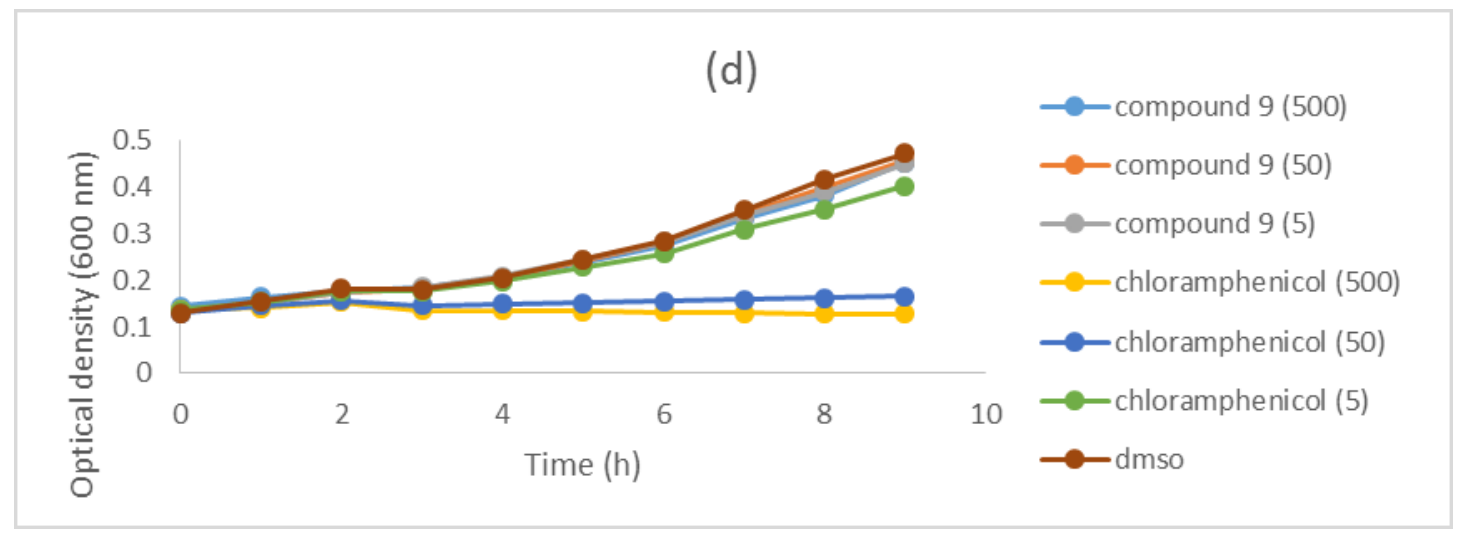




\section{D: Strain collection sites and preliminary bioassay screening results.}

Table D1. The collection of fungi strains screened.

\begin{tabular}{|c|c|c|c|c|}
\hline \multirow[t]{2}{*}{ Strains and species } & \multirow{2}{*}{$\begin{array}{c}\text { Additional } \\
\text { information }\end{array}$} & \multirow[t]{2}{*}{ Collection site } & \multicolumn{2}{|c|}{ Bioassay results } \\
\hline & & & $\begin{array}{c}\text { Saccharomyces } \\
\text { cervisae }\end{array}$ & $\begin{array}{c}\text { Microbotryum } \\
\text { violaceum }\end{array}$ \\
\hline $\begin{array}{c}\text { A1 FB2 } \\
\text { Aylmer Mollisia }\end{array}$ & & $\begin{array}{c}\text { Old hardwood } \\
\log \text { (Aylmer, } \\
\text { QC) }\end{array}$ & - & - \\
\hline $\begin{array}{c}\mathrm{H} 1 \\
\text { Keith Mollisia }\end{array}$ & & $\begin{array}{l}\text { Old conifer log } \\
\text { (Stittsville, } \\
\text { ON) }\end{array}$ & - & - \\
\hline B2 236-1B & $\begin{array}{c}\text { Closest BLAST } \\
\text { taxa } \\
\text { Hyphodiscus } \\
\text { hymeniophilus }\end{array}$ & $\begin{array}{c}\text { Picea mariana } \\
\text { needle isolation } \\
\text { (Gagetown) }\end{array}$ & - & - \\
\hline C2 285-5B & $\begin{array}{l}\text { Closest BLAST } \\
\text { taxa } \\
\text { Lachnum sp. }\end{array}$ & $\begin{array}{c}\text { Picea rubens } \\
\text { needle isolation } \\
\text { (Doaktown 2) }\end{array}$ & $\checkmark$ & $\checkmark$ \\
\hline $\begin{array}{c}\text { NB } 258 \text { G2 } \\
\text { Bruce Mollisia }\end{array}$ & & $\begin{array}{l}\text { Fruiting body } \\
\text { on dead } \\
\text { Eriophorum } \\
\text { angustifolium } \\
\text { (Bull Pasture } \\
\text { Bog) }\end{array}$ & - & $\checkmark$ \\
\hline E3 285-4F & $\begin{array}{c}\text { Closest BLAST } \\
\text { taxa } \\
\text { Phialocephala } \\
\text { scopiformis }\end{array}$ & $\begin{array}{c}\text { Picea rubens } \\
\text { needle isolation } \\
\text { (Doaktown 2) }\end{array}$ & $\checkmark$ & $\checkmark$ \\
\hline A4 250-4F & Closest BLAST & $\begin{array}{l}\text { Picea mariana } \\
\text { needle isolation }\end{array}$ & $\checkmark$ & $\checkmark$ \\
\hline
\end{tabular}




\begin{tabular}{|c|c|c|c|c|}
\hline & $\begin{array}{c}\text { taxa } \\
\text { Arachnopeziza } \\
\text { aurata }\end{array}$ & (Doaktown 2) & & \\
\hline $\begin{array}{c}\mathrm{H} 4285-4 \mathrm{D} \\
\text { Pseudoplectania nigrella }\end{array}$ & & $\begin{array}{c}\text { Picea rubens } \\
\text { needle isolation } \\
\text { (Doaktown 2) }\end{array}$ & - & $\checkmark$ \\
\hline B5 285-3B & $\begin{array}{c}\text { Closest BLAST } \\
\text { taxa } \\
\text { Xylaria sp. }\end{array}$ & $\begin{array}{c}\text { Picea rubens } \\
\text { needle isolation } \\
\text { (Doaktown 2) }\end{array}$ & - & - \\
\hline E6 285-6A & $\begin{array}{c}\text { Closest BLAST } \\
\text { taxa } \\
\text { Xylaria sp. }\end{array}$ & $\begin{array}{c}\text { Picea rubens } \\
\text { needle isolation } \\
\text { (Doaktown 2) }\end{array}$ & - & - \\
\hline $\begin{array}{c}\text { H6 250-4H } \\
\text { (unidentified species) }\end{array}$ & & $\begin{array}{c}\text { Picea mariana } \\
\text { needle isolation } \\
\text { (Doaktown 2) }\end{array}$ & - & $\checkmark$ \\
\hline NB-121 E7 1991-2A & $\begin{array}{c}\text { Closest BLAST } \\
\text { taxa } \\
\text { Rhizosphaera } \\
\text { kalkhoffii }\end{array}$ & $\begin{array}{l}\text { Pinus strobus } \\
\text { needle isolation } \\
\text { (elite tree } \\
\text { 1991-2A; } \\
\text { Sussex) }\end{array}$ & - & - \\
\hline $\begin{array}{l}\text { D8 } 173 \\
\text { Phialocephala scopiformis }\end{array}$ & & $\begin{array}{c}\text { Fruiting body } \\
\text { on half buried } \\
\text { Pinus rubens } \\
\text { branch }\end{array}$ & $\checkmark$ & $\checkmark$ \\
\hline $\begin{array}{c}\text { E8 } 175 \\
\text { Lachnum papyraceum }\end{array}$ & & $\begin{array}{l}\text { Picea rubens } \\
\text { on ground with } \\
\text { fruit body, } \\
\text { Albright's } \\
\text { Corner (north } \\
\text { of Gagetown), } \\
\text { NB }\end{array}$ & $\checkmark$ & $\checkmark$ \\
\hline
\end{tabular}




\begin{tabular}{|c|c|c|c|c|}
\hline HB 105-2B & $\begin{array}{c}\text { Closest BLAST } \\
\text { taxa } \\
\text { Phialocephala } \\
\text { dimorphospora }\end{array}$ & $\begin{array}{c}\text { Pinus strobus } \\
\text { needle isolation } \\
\text { (elite tree 804- } \\
\text { 1A; Sussex) }\end{array}$ & - & - \\
\hline $\begin{array}{c}\text { E10 250-1A } \\
\text { Thysanophora penicillioides }\end{array}$ & & $\begin{array}{l}\text { Picea mariana } \\
\text { needle isolation } \\
\text { (Doaktown 2) }\end{array}$ & - & $\checkmark$ \\
\hline D12 236-2I & $\begin{array}{c}\text { Closest BLAST } \\
\text { taxa } \\
\text { Xylaria } \\
\text { castorea }\end{array}$ & $\begin{array}{c}\text { Picea mariana } \\
\text { needle isolation } \\
\text { (Gagetown) }\end{array}$ & - & $\checkmark$ \\
\hline $\begin{array}{c}\text { NB 236-1A } \\
\text { (unidentified species) }\end{array}$ & & $\begin{array}{l}\text { Living Needles } \\
\text { from lower } \\
\text { crown of living } \\
6 \mathrm{~cm} \text { DBH } \\
\text { Picea mariana }\end{array}$ & $\checkmark$ & $\checkmark$ \\
\hline $\begin{array}{c}\text { NB 285-2B } \\
\text { (unidentified species) }\end{array}$ & & $\begin{array}{c}\text { Living needles } \\
\text { from } 3 \mathrm{~m} \text { tall } \\
\text { Picea rubens } \\
\text { understorey } \\
\text { tree }\end{array}$ & $\checkmark$ & - \\
\hline $\begin{array}{c}\text { NB 115-4A } \\
\text { (unidentified species) }\end{array}$ & & $\begin{array}{l}\text { Living needles } \\
\text { from Pinus } \\
\text { strobus (elite } \\
\text { tree 1058-2) }\end{array}$ & $\checkmark$ & $\checkmark$ \\
\hline $\begin{array}{c}\text { AW } 527 \text { NB-92C } \\
\text { Hymenoscyphus janthinum }\end{array}$ & & $\begin{array}{l}\text { White pine, } \\
\text { Doaktown, NB }\end{array}$ & - & - \\
\hline $\begin{array}{c}\text { AW } 529 \\
\text { Lophodermium sp. }\end{array}$ & & $\begin{array}{c}\text { Jack pine, } \\
\text { Lepreau, NB }\end{array}$ & - & $\checkmark$ \\
\hline $\begin{array}{c}\mathrm{AW} 532 \\
\text { Hymenoscyphus janthinum }\end{array}$ & & $\begin{array}{l}\text { White pine, } \\
\text { Doaktown, NB }\end{array}$ & - & - \\
\hline
\end{tabular}




\begin{tabular}{|c|c|c|c|}
\hline $\begin{array}{c}\text { AW } 534 \\
\text { Leotiomycetes sp. }\end{array}$ & $\begin{array}{c}\text { Sorbus } \\
\text { americana } \\
\text { (understory), } \\
\text { Little Lepreau, } \\
\text { NB }\end{array}$ & - & - \\
\hline $\begin{array}{c}\text { AW } 535 \\
\text { Rhytismataceae sp. }\end{array}$ & $\begin{array}{c}\text { Jack pine, } \\
\text { Lepreau, NB }\end{array}$ & - & - \\
\hline $\begin{array}{c}\text { AW } 545 \\
\text { Phomopsis sp. }\end{array}$ & $\begin{array}{l}\text { Red spruce, } \\
\text { Lepreau, NB }\end{array}$ & - & $\checkmark$ \\
\hline $\begin{array}{l}\text { AW } 550 \text { NB-304 } \\
\text { Lophodermium sp. }\end{array}$ & $\begin{array}{l}\text { Red spruce, } \\
\text { Lepreau, NB }\end{array}$ & - & $\checkmark$ \\
\hline $\begin{array}{l}\text { AW } 554 \text { NB-328 } \\
\text { Phialocephala sp. }\end{array}$ & $\begin{array}{c}\text { Red spruce, JD } \\
\text { Irving Nature } \\
\text { Park }\end{array}$ & - & - \\
\hline $\begin{array}{c}\text { AW } 555 \text { NB-328 } \\
\text { Ascocoryne sp. }\end{array}$ & $\begin{array}{c}\text { Red spruce, JD } \\
\text { Irving Nature } \\
\text { Park }\end{array}$ & - & - \\
\hline $\begin{array}{c}\text { NB } 330 \\
\text { Seimatosporium sp. }\end{array}$ & $\begin{array}{c}\text { Rhododendron } \\
\text { groenlandicum } \\
\text { (Labrador tea, } \\
\text { understory) JD } \\
\text { Irving Nature } \\
\text { Park }\end{array}$ & $\checkmark$ & $\checkmark$ \\
\hline $\begin{array}{c}\text { AW } 518 \text { NB-106 } \\
\text { Itersonilia perplexans }\end{array}$ & $\begin{array}{l}\text { White pine, } \\
\text { Sussex, NB }\end{array}$ & - & - \\
\hline $\begin{array}{c}\text { AW } 525 \text { NB-79b } \\
\text { Xenochalara juniperi }\end{array}$ & $\begin{array}{c}\text { White pine, } \\
\text { Doaktown, NB }\end{array}$ & - & - \\
\hline NB 209 & $\begin{array}{l}\text { Abies balsamea } \\
\text { fallen log with }\end{array}$ & $\checkmark$ & $\checkmark$ \\
\hline
\end{tabular}




\begin{tabular}{|c|c|c|c|}
\hline Lachnum sp. & $\begin{array}{c}\text { fruit body, } \\
\text { Gagetown, NB }\end{array}$ & & \\
\hline $\begin{array}{l}\text { NB 242-B } \\
\text { Mollisia sp. }\end{array}$ & $\begin{array}{c}\text { dead } \\
\text { alder/birch } \\
\text { stem in beaver } \\
\text { lodge, } \\
\text { Gagetown, NB }\end{array}$ & - & - \\
\hline $\begin{array}{c}\text { NB-192 } \\
\text { Vibrissea truncorum }\end{array}$ & & - & - \\
\hline $\begin{array}{c}\text { NB-221 } \\
\text { Phacidiopycnis sp. }\end{array}$ & Black spruce & - & - \\
\hline $\begin{array}{l}\text { AW } 540 \text { NB-92-P1D } \\
\text { Neonectria ramulariae }\end{array}$ & $\begin{array}{c}\text { White pine } \\
\text { needles } \\
\text { Doaktown, NB }\end{array}$ & - & $\checkmark$ \\
\hline $\begin{array}{l}\text { AW } 524 \text { NB-108C } \\
\text { (unidentified species) }\end{array}$ & $\begin{array}{l}\text { white pine } \\
\text { Sussex, NB }\end{array}$ & - & - \\
\hline $\begin{array}{l}\text { AW } 520 \text { NB-123-2A } \\
\text { (unidentified species) }\end{array}$ & $\begin{array}{l}\text { White pine, } \\
\text { Sussex, NB }\end{array}$ & - & - \\
\hline $\begin{array}{l}\text { AW } 521 \text { NB-151-1F } \\
\text { Lophodermium sp. }\end{array}$ & $\begin{array}{c}\text { Jack pine, } \\
\text { Lepreau, NB }\end{array}$ & - & $\checkmark$ \\
\hline $\begin{array}{l}\text { AW } 516 \text { NB-111-2C } \\
\text { (unidentified species) }\end{array}$ & $\begin{array}{l}\text { White pine, } \\
\text { Sussex, NB }\end{array}$ & - & - \\
\hline $\begin{array}{l}\text { AW } 522 \text { NB- 122a } \\
\text { (unidentified species) }\end{array}$ & $\begin{array}{l}\text { White pine, } \\
\text { Sussex, NB }\end{array}$ & - & - \\
\hline $\begin{array}{l}\text { AW } 523 \text { NB-105b } \\
\text { Alternaria alternata }\end{array}$ & $\begin{array}{l}\text { White pine, } \\
\text { Sussex, NB }\end{array}$ & $\checkmark$ & $\checkmark$ \\
\hline $\begin{array}{c}\text { AW } 526 \text { NB-92-P3b } \\
\text { Neonectria ramulariae }\end{array}$ & $\begin{array}{c}\text { White pine, } \\
\text { Doaktown, NB }\end{array}$ & - & - \\
\hline
\end{tabular}




\begin{tabular}{|c|c|c|c|}
\hline $\begin{array}{l}\text { AW } 541 \text { NB-145b(1) } \\
\text { Lophodermium sp. }\end{array}$ & $\begin{array}{c}\text { Sorbus } \\
\text { americana } \\
\text { (understory), } \\
\text { Little Lepreau, } \\
\text { NB }\end{array}$ & $\checkmark$ & $\checkmark$ \\
\hline $\begin{array}{c}\text { AW } 531 \\
\text { Lophodermium sp. }\end{array}$ & $\begin{array}{c}\text { Sorbus } \\
\text { americana } \\
\text { (understory), } \\
\text { Little Lepreau, } \\
\text { NB }\end{array}$ & $\checkmark$ & $\checkmark$ \\
\hline $\begin{array}{l}\text { AW } 519 \text { NB-123-3D } \\
\text { Epicoccum nigrum }\end{array}$ & $\begin{array}{l}\text { White pine, } \\
\text { Sussex, NB }\end{array}$ & - & - \\
\hline $\begin{array}{c}\text { AW } 537 \text { NB-92-C(2) } \\
\text { Leotiomycetes sp. }\end{array}$ & $\begin{array}{c}\text { Jack pine, } \\
\text { Lepreau, NB }\end{array}$ & - & - \\
\hline $\begin{array}{l}\text { AW } 542 \text { NB-92-P1-B } \\
\text { unidentified fungus }\end{array}$ & $\begin{array}{c}\text { White pine } \\
\text { Doaktown, NB }\end{array}$ & - & - \\
\hline $\begin{array}{l}\text { AW } 536 \text { NB-92-P2A } \\
\text { (unidentified species) }\end{array}$ & $\begin{array}{c}\text { White pine } \\
\text { Doaktown, NB }\end{array}$ & - & - \\
\hline $\begin{array}{l}\text { AW } 538 \text { NB-92-P2D } \\
\text { unidentified fungus }\end{array}$ & $\begin{array}{c}\text { White pine } \\
\text { Doaktown, NB }\end{array}$ & - & - \\
\hline $\begin{array}{l}\text { AW } 528 \text { NB-92-P2B } \\
\text { Neonectria ramulariae }\end{array}$ & $\begin{array}{l}\text { White pine in } \\
\text { Doaktown }\end{array}$ & - & $\checkmark$ \\
\hline $\begin{array}{c}\mathrm{AW} 544 \\
\text { Lophodermium sp. }\end{array}$ & $\begin{array}{l}\text { White pine in } \\
\text { Sussex }\end{array}$ & $\checkmark$ & $\checkmark$ \\
\hline $\begin{array}{c}\text { AW } 548 \\
\text { (unidentified species) }\end{array}$ & $\begin{array}{c}\text { Red spruce } \\
\text { Lepreau }\end{array}$ & - & - \\
\hline AW 549 & $\begin{array}{c}\text { Red spruce } \\
\text { Lepreau }\end{array}$ & $\checkmark$ & $\checkmark$ \\
\hline
\end{tabular}




\begin{tabular}{|c|c|c|c|}
\hline (unidentified species) & & & \\
\hline $\begin{array}{c}\text { NB-285-3E } \\
\text { Unknown } \\
\text { Lophodermium/Rhytismatales }\end{array}$ & $\begin{array}{c}\text { Picea rubens } \\
\text { needle isolation } \\
\text { (Doaktown 2) }\end{array}$ & - & - \\
\hline $\begin{array}{c}\text { NB-250-4A } \\
\text { Phaeocryptopus gaeumannii }\end{array}$ & $\begin{array}{c}\text { Picea mariana } \\
\text { needle isolation } \\
\text { (Doaktown 2) }\end{array}$ & - & - \\
\hline $\begin{array}{c}\text { NB-277-3A } \\
\text { Peniophora sp. }\end{array}$ & $\begin{array}{c}\text { Picea rubens } \\
\text { needle isolation } \\
\text { (Doaktown 1) }\end{array}$ & - & - \\
\hline $\begin{array}{c}\text { NB-3619-2D } \\
\text { Celosporium larixicola }\end{array}$ & $\begin{array}{l}\text { Pinus strobus } \\
\text { needle isolation } \\
\text { (Sussex, NB) }\end{array}$ & - & $\checkmark$ \\
\hline $\begin{array}{c}\text { NB-399 } \\
\text { Hyderia abietis }\end{array}$ & $\begin{array}{l}\text { Fruiting body } \\
\text { on Picea } \\
\text { rubens needle } \\
\quad \text { litter }\end{array}$ & $\checkmark$ & $\sqrt{ }$ \\
\hline $\begin{array}{c}\text { NB-369 } \\
\text { Mollisia sp. }\end{array}$ & $\begin{array}{c}\text { decaying } \\
\text { hardwood on } \\
\text { ground } \\
\text { (Dickson's } \\
\text { Falls, Alma, } \\
\text { NB) }\end{array}$ & - & - \\
\hline $\begin{array}{c}\text { NB-377 } \\
\text { Mollisia sp. }\end{array}$ & $\begin{array}{l}\text { On well-rotted } \\
\text { decorticated } \\
\text { yellow birch } \\
\text { log (Maple } \\
\text { Grove, Alma, } \\
\text { NB) }\end{array}$ & - & - \\
\hline $\begin{array}{c}\text { NB-236-2H } \\
\text { (unidentified species) }\end{array}$ & $\begin{array}{c}\text { Picea mariana } \\
\text { needle isolation } \\
\text { (Gagetown) }\end{array}$ & - & $\sqrt{ }$ \\
\hline NB-373a & $\begin{array}{c}\text { Well-rotted } \\
\text { yellow birch or }\end{array}$ & - & - \\
\hline
\end{tabular}




\begin{tabular}{|c|c|c|c|c|}
\hline Mollisia $\mathrm{sp}$. & & $\begin{array}{c}\text { sugar maple } \\
\text { log (Maple } \\
\text { Grove, Alma, } \\
\text { NB) }\end{array}$ & & \\
\hline $\begin{array}{c}\text { NB-402 } \\
\text { Hyaloscypha sp. }\end{array}$ & & $\begin{array}{l}\text { Picea rubens } \\
\text { cone on ground } \\
\text { (Wolfe Point, } \\
\text { Alma, NB) }\end{array}$ & - & $\sqrt{ }$ \\
\hline $\begin{array}{c}\text { NB-236-2B } \\
\text { (unidentified species) }\end{array}$ & & $\begin{array}{l}\text { Living needles } \\
\text { from lower } \\
\text { crown of living } \\
6 \mathrm{~cm} \text { DBH } \\
\text { Picea mariana }\end{array}$ & - & - \\
\hline $\begin{array}{c}\text { NB-250-1E } \\
\text { (unidentified species) }\end{array}$ & & $\begin{array}{l}\text { Living needles } \\
\text { from dwarf } \\
\text { Picea mariana } \\
\text { in Bull Pasture } \\
\text { Bog }\end{array}$ & - & - \\
\hline D11-249-2D & $\begin{array}{c}\text { Closest BLAST } \\
\text { taxa } \\
\text { Lophodermium } \\
\text { piceae }\end{array}$ & $\begin{array}{c}\text { Picea mariana } \\
\text { needle } \\
\text { isolation, Bull } \\
\text { Pasture Bog }\end{array}$ & - & - \\
\hline $\begin{array}{c}\text { NB-250-4G } \\
\text { (unidentified species) }\end{array}$ & & $\begin{array}{l}\text { Living needles } \\
\text { from dwarf } \\
\text { Picea mariana } \\
\text { in Bull Pasture } \\
\text { Bog }\end{array}$ & - & - \\
\hline E4-236-2A & & $\begin{array}{c}\text { Picea mariana } \\
\text { needle } \\
\text { isolation, } \\
\text { Gagetown, NB }\end{array}$ & - & - \\
\hline
\end{tabular}




\begin{tabular}{|c|c|c|c|}
\hline $\begin{array}{c}\text { NB-221-2E } \\
\text { Lachnum virgineum }\end{array}$ & $\begin{array}{c}\text { Needle } \\
\text { isolations from } \\
\text { small }(2 \mathrm{~cm} \\
\text { DBH) black } \\
\text { spruce; } \\
\text { Gagetown, NB }\end{array}$ & - & $\bar{\checkmark}$ \\
\hline $\begin{array}{c}\text { NB-283-4N } \\
\text { Chalara holubovae }\end{array}$ & $\begin{array}{c}\text { Needle } \\
\text { isolations from } \\
\text { natural white } \\
\text { pine } \\
\text { regeneration; } \\
\text { Doaktown, NB }\end{array}$ & - & $\checkmark$ \\
\hline $\begin{array}{c}\text { NB-382-3D } \\
\text { Pezicula sporulosa }\end{array}$ & $\begin{array}{c}\text { Needle } \\
\text { isolations from } \\
\sim 6 \mathrm{~cm} \text { DBH red } \\
\text { spruce in } \\
\text { yellow birch } \\
\text { and red maple } \\
\text { stand; Alma, } \\
\text { NB }\end{array}$ & - & $\checkmark$ \\
\hline $\begin{array}{c}\text { NB-334-1B } \\
\text { Melanconis alni }\end{array}$ & $\begin{array}{l}\text { Needle } \\
\text { isolations from } \\
\text { red spruce; } \\
\text { Alma, NB }\end{array}$ & - & - \\
\hline $\begin{array}{c}\text { NB-334-18C } \\
\text { Acephala (Phialocephala) sp. }\end{array}$ & $\begin{array}{l}\text { Needle } \\
\text { isolations from } \\
\text { red spruce; } \\
\text { Alma, NB }\end{array}$ & - & - \\
\hline $\begin{array}{c}\text { NB-221-5B } \\
\text { Dwayaangam colodena }\end{array}$ & $\begin{array}{c}\text { Needle } \\
\text { isolations from } \\
\text { small }(2 \mathrm{~cm} \\
\text { DBH) black } \\
\text { spruce; } \\
\text { Gagetown, NB }\end{array}$ & $\checkmark$ & $\bar{\checkmark}$ \\
\hline $\begin{array}{c}\text { NB-283-3C } \\
\text { Meloderma desmazieresii }\end{array}$ & $\begin{array}{c}\text { Needle } \\
\text { isolations from } \\
\text { natural white } \\
\text { pine } \\
\text { regeneration; }\end{array}$ & $\checkmark$ & $\checkmark$ \\
\hline
\end{tabular}




\begin{tabular}{|c|c|c|c|}
\hline & Doaktown, NB & & \\
\hline $\begin{array}{c}\text { NB-221-3D } \\
\text { Tryblidiopsis pinastri }\end{array}$ & $\begin{array}{c}\text { Needle } \\
\text { isolations from } \\
\text { small }(2 \mathrm{~cm} \\
\text { DBH) black } \\
\text { spruce; } \\
\text { Gagetown, NB }\end{array}$ & - & $\checkmark$ \\
\hline $\begin{array}{c}\text { NB-392-3M } \\
\text { Collophora capensis }\end{array}$ & $\begin{array}{l}\text { Needle } \\
\text { isolations from } \\
\text { red spruce; } \\
\text { Alma, NB }\end{array}$ & $\checkmark$ & $\checkmark$ \\
\hline $\begin{array}{c}\text { NB-365-71I } \\
\text { Diaporthe celastrina }\end{array}$ & $\begin{array}{l}\text { Needle } \\
\text { isolations from } \\
\text { red spruce; } \\
\text { Alma, NB }\end{array}$ & - & $\sqrt{ }$ \\
\hline $\begin{array}{c}\text { NB-182 } \\
\text { Lachnum virgineum }\end{array}$ & $\begin{array}{c}\text { Lachnum } \\
\text { fruiting on } \\
\text { fallen red } \\
\text { spruce cone; } \\
\text { Grand Lake } \\
\text { Meadow, NB }\end{array}$ & - & $\sqrt{ }$ \\
\hline $\begin{array}{c}\text { NB-334-3C } \\
\text { Septorioides pini-thunbergii }\end{array}$ & $\begin{array}{l}\text { Needle } \\
\text { isolations from } \\
\text { red spruce; } \\
\text { Alma, NB }\end{array}$ & - & $\checkmark$ \\
\hline $\begin{array}{c}\text { NB-365-71F } \\
\text { Lophodermium jiangnanense }\end{array}$ & $\begin{array}{l}\text { Needle } \\
\text { isolations from } \\
\text { red spruce; } \\
\text { Alma, NB }\end{array}$ & - & - \\
\hline $\begin{array}{c}\text { NB-250-1D } \\
\text { Leptodontidium sp. }\end{array}$ & $\begin{array}{c}\text { Needle } \\
\text { isolations from } \\
\text { dwarf black } \\
\text { spruce in Bull } \\
\text { Pasture Bog; } \\
\text { Minto, NB }\end{array}$ & - & $\sqrt{ }$ \\
\hline
\end{tabular}

: biological activity observed 